UNIVERSIDADE DE SÃO PAULO

SIMONE HENRIQUE

\title{
O DIREITO FUNDAMENTAL À SAÚDE DA MULHER NEGRA NO MUNICÍPIO DE SÃO PAULO
}

\author{
DISSERTAÇÃO DE MESTRADO \\ PROFESSORA ORIENTADORA \\ EUNICE APARECIDA DE JESUS PRUDENTE
}

SÃO PAULO

2013 
UNIVERSIDADE DE SÃO PAULO

SIMONE HENRIQUE

\section{O DIREITO FUNDAMENTAL À SAÚDE DA MULHER NEGRA NO MUNICÍPIO DE SÃO PAULO}

Dissertação apresentada à banca examinadora da Faculdade de Direito da Universidade de São Paulo como exigência parcial para obtenção do título de Mestre em Direito.

Área de Concentração: Direitos Humanos

Orientadora: Professora Doutora Eunice

Aparecida de Jesus Prudente

SÃO PAULO

2013 
Henrique, Simone.

H448d O direito fundamental à saúde da mulher negra no município de São Paulo/Simone Henrique. - - São Paulo: USP / Faculdade de Direito, 2013.

$125 \mathrm{f}$.

Orientadora: Prof $\mathrm{Dr}^{\mathrm{a}}$. Eunice Aparecida de Jesus Prudente.

Dissertação (Mestrado), Universidade de São Paulo, USP, Programa de Pós-Graduação em Direito, 2013.

1. Direitos Humanos. 2. Direitos da Mulher. 3. Direito à Saúde. 4. Negros. 5. Políticas Públicas. I. Prudente, Eunice Aparecida de Jesus. II. Universidade de São Paulo, Faculdade de Direito, Programa de Pós-Graduação em Direito. III. Título. 
Nome: HENRIQUE, Simone

Título: O direito fundamental à saúde da mulher negra no município de São Paulo.

Dissertação apresentada à Faculdade de Direito da Universidade de São Paulo para a obtenção do título de Mestre em Direito

Aprovada em:

Banca Examinadora

Prof. Dr. Instituição:

Julgamento: Assinatura:

Prof. Dr. Instituição:

Julgamento: Assinatura:

Prof. Dr. Instituição:

Julgamento: Assinatura: 
Dedico este trabalho aos meus pais, meus eternos professores na escola da Vida. Às companheiras inspiradoras do Geledés - Instituto da Mulher Negra e da União de Mulheres da Cidade de São Paulo. 


\section{AGRADECIMENTOS}

Agradeço em primeiro plano ao Eterno e ao Plano Superior por seu amor infinito e incondicional.

Quero agradecer à minha família material e espiritual. Renovo minha Fé e minha vontade de vencer a cada instante, pois sei que posso contar com vocês na alegria e na dor.

Sou grata à minha orientadora, Professora Doutora Eunice Aparecida de Jesus Prudente, por sua confiança em meu trabalho de pesquisadora, sua generosidade na construção do saber e a oportunidade singular de ser sua orientanda, monitora das Disciplinas Teoria Geral do Estado I e II junto às turmas da Graduação e convidada das reuniões do NEINB-USP (Núcleo de Estudos Interdisciplinares sobre a/o Negra/o Brasileira/o da Universidade de São Paulo).

À Professora Doutora Elza Antônia Pereira Cunha Boiteux, pelas observações criteriosas e excelentes indicações bibliográficas por ocasião do Exame de Qualificação que redundaram em uma nova apresentação do próprio trabalho.

À Professora Doutora Denise Auad, pela análise detalhada do texto, as correções na Qualificação e o exercício da monitoria voluntária da Disciplina Prática Constitucional na Faculdade de Direito de São Bernardo do Campo.

Aos Professores do Programa de Pós-Graduação em Direito, ministrantes das disciplinas obrigatórias e eletivas da Área de Concentração em Direitos Humanos: Gislene Aparecida dos Santos, Marcus Orione Correia Gonçalves, Eduardo Carlos Bianca Bittar, André de Carvalho Ramos, Calixto Salomão Filho, Celso Lafer, Guilherme Assis de Almeida, José Eduardo Campos de Oliveira Faria, Mônica Herman Salem Caggiano e Nina Beatriz Stocco Ranieri. 
Aos Professores de outras Unidades da Universidade de São Paulo, anoto os meus agradecimentos pela gentil acolhida e partilha do conhecimento nas minhas disciplinas eletivas: Maria Cristina Komatsu Braga Massarollo e Vera Lucia Mira (Escola de Enfermagem), Eduardo Cesar Leão Marques (Faculdade de Filosofia, Letras e Ciências Humanas), Sueli Gandolfi Dallari, Paulo Capel Narvai e Oswaldo Tanaka ( Faculdade de Saúde Pública) e Ana Paula Fracalanza e Ursula Dias Peres ( Escola de Artes, Ciências e Humanidades).

Aos meus amigos orientadores/conselheiros desde os tempos da graduação: Yata Fernanda Sampaio de Souza, Priscila Junqueira Ferreira, Diana Satiri Mitsuse Murao, Walerye Yasuda e Fernando Chocair Felício.

Aos meus colegas pesquisadores na Pós-Graduação na Faculdade de Direito, orientandos da Professora Doutora Eunice Prudente que transformaram uma jornada de desafios em momentos de alegria e amizade: Vinicius Mota de Jesus e Edinaldo César Santos Júnior: minha gratidão, carinho e votos de bênçãos! Aos pesquisadores das áreas de Direitos Humanos, Direito do Estado e monitoria de Teoria Geral do Estado: Denise Martins Moretti, Renata Cristina Antão, Pablo Biondi, Tatiana Waldman, Pedro Pulzatto Peruzzo, Bruno Batista Oliveira, Carolina Oliboni Bastos, Murilo Gaspardo e Carlos Eduardo Targino: meus agradecimentos especiais.

Meus agradecimentos às amáveis e acolhedoras colegas pesquisadoras da Escola de Enfermagem Programa de Pós-Graduação em Gerenciamento de Serviços de Saúde. Agradeço também aos colegas do Grupo de Pesquisa em Participação Política e Gestão Participativa da Escola de Artes, Ciências e Humanidades pelos calorosos debates. 
Minha gratidão especial aos colaboradores da Secretaria de Pós-Graduação (nomeadamente Senhora Cida e Senhora Fátima), da equipe da Biblioteca Circulante e da Biblioteca do Departamento de Direito do Estado (Senhora Raquel) e um destaque para a Senhora Vera Lúcia e ao Senhor Leandro da Secretaria do Departamento de Direito do Estado.

E, por fim, agradeço à Fundação Carlos Chagas (FCC) pelo apoio dado a esta pesquisa até o mês de setembro de 2012. 
"Pra mostrar que mulher tem coragem, pra mostrar que mulher tem imagem, pra mostrar que mulher tem respeito, pra mostrar que mulher tem conceito, pra mostrar que mulher também tem direito de bater o pé." ( "Deolinda-Benvinda", Leci Brandão) 
HENRIQUE, S. O direito fundamental à saúde da mulher negra no município de São Paulo. 2013. Dissertação (Mestrado) - Faculdade de Direito, Universidade de São Paulo, 2013.

\section{RESUMO}

O objetivo desta dissertação é estudar o direito fundamental à saúde da mulher negra no município de São Paulo.

O direito à saúde é um direito humano fundamental, mas no exercício desse direito as mulheres negras sofrem dois tipos de discriminação: a racial e a de gênero.

O primeiro capítulo é uma reflexão sobre os direitos humanos e os direitos fundamentais, histórico, natureza e características. A pesquisa está relacionada ao estudo dos Direitos Humanos, tendo como ponto de partida a sua construção histórica. A Constituição Brasileira de 1988 representou a positivação de direitos fundamentais e a proteção do valor fonte dignidade humana. O legislador constituinte positivou expressamente a igualdade racial, os direitos fundamentais das mulheres e o direito fundamental à saúde.

Já o segundo capítulo ressalta a importância da constitucionalização do direito à saúde, a doutrina do direito sanitário e o estudo das políticas públicas. Relativamente à perspectiva dos Direitos Humanos, apontamos a imbricação entre o feminismo dos anos 1970-1980 e o movimento negro organizado na luta pela igualdade de gênero e igualdade racial.

O capítulo terceiro versa sobre a política pública de direito à saúde da mulher negra nos planos nacional, estadual e municipal. E por fim, apresentamos a nossa proposta de Educação em Direitos Humanos.

Palavras-chave: Direitos humanos; Direitos da mulher; Direito à Saúde; Negros; Políticas Públicas. 
HENRIQUE, S. The fundamental right to health of black woman in São Paulo. 2013.125 f. Dissertação ( Mestrado) - Faculdade de Direito, Universidade de São Paulo, 2013.

\section{ABSTRACT}

The objective of this dissertation is to study the fundamental right to health of black woman in São Paulo.

The right to health is a fundamental human right but, in exercising that right, black women suffer two types of discrimination: of race and gender.

The first chapter is a reflection on the human and fundamental rights, history, nature and characteristics. The research is related to the study of human rights, using their historical construction as the starting point. The Brazilian Constitution of 1988 represented the protective legalization of fundamental rights and its cornerstone, which is the human dignity. The statute expressly constituted racial equality, fundamental rights of women and the fundamental right to health.

The second chapter highlights the importance of making constitutional the right to health, the sanitary law doctrine and the study of public policy. For the perspective of Human Rights, we point out the overlap between the years 1970-1980 feminism and organized black movement in the struggle for gender and racial equality.

The third and the fourth chapters deals with the public policy of the right to health of black woman at the under national, state and municipal views. Finally, we present our proposal for education in Human Rights.

Keywords: Human Rights, Women's Rights, Right to Health; Black people; Public Policy. 


\section{SUMÁRIO}

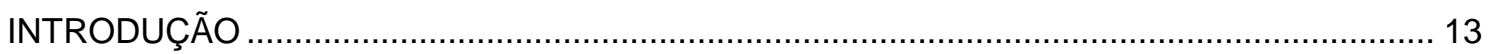

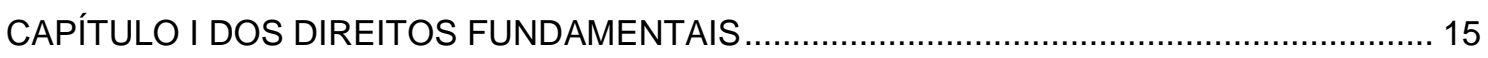

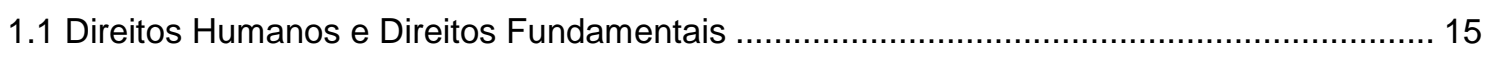

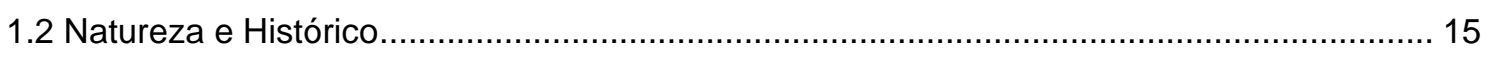

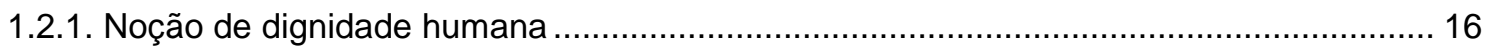

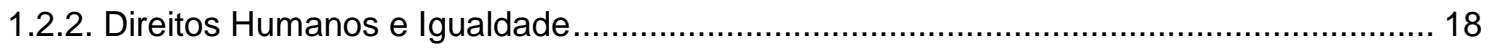

1.2.3 Direitos Humanos e Direitos Fundamentais ............................................................ 20

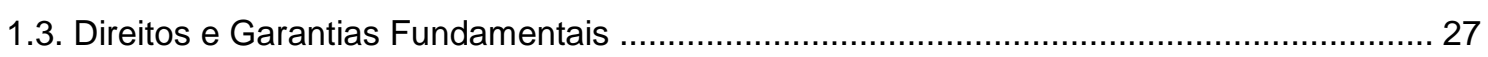

CAPÍTULO II O DIREITO FUNDAMENTAL À SAÚDE NO BRASIL ........................................ 29

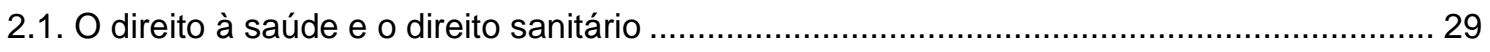

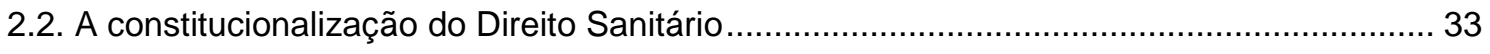

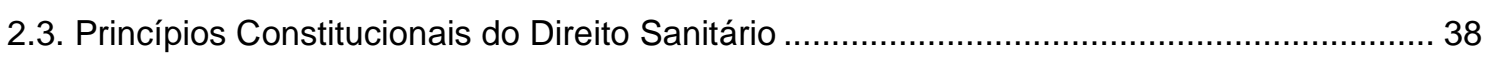

2.4. A reforma sanitária e o direito fundamental à saúde ........................................................... 47

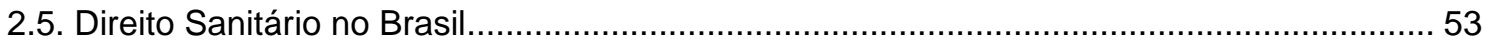

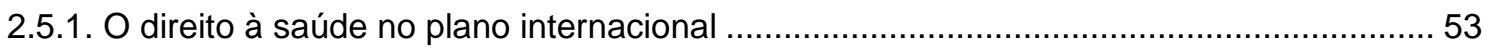

2.6. O papel do Poder Executivo nacional na construção do direito à saúde ............................ 56

2.7. O papel do Poder Legislativo na construção do direito à saúde ........................................... 57

2.8. O papel do Poder Judiciáio na construção do direito à saúde ........................................... 57

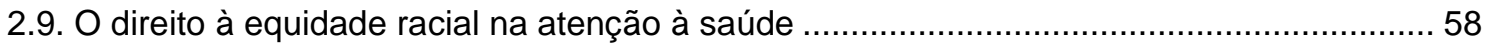

CAPÍTULO III - A POLÍTICA PÚBLICA DE PROMOÇÃO DO DIREITO À SAÚDE DA MULHER

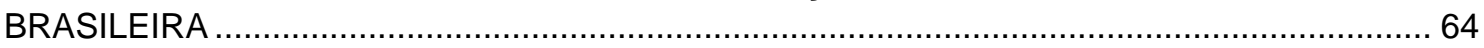

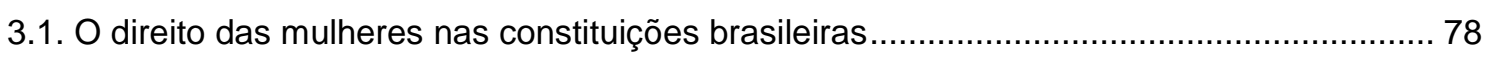

CAPÍTULO IV- A POLÍTICA PÚBLICA DE DIREITO À SAÚDE DA POPULAÇÃO NEGRA ...... 93

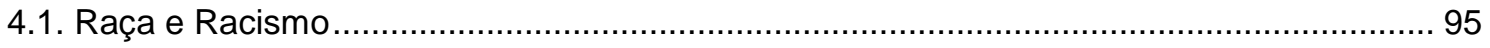

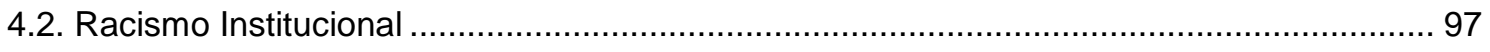

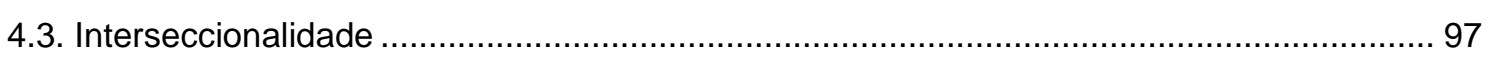

4.4. Política Nacional de Saúde Integral da População Negra- PNSIPN ............................... 101

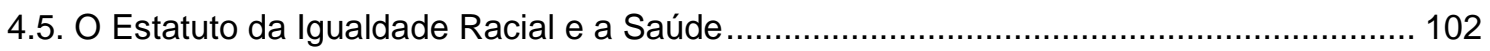

4.6. O Programa Estadual de Políticas Afirmativas do Estado de São Paulo .......................... 107

4.7. A Política Pública de Promoção da Igualdade Racial no município de São Paulo ............ 109

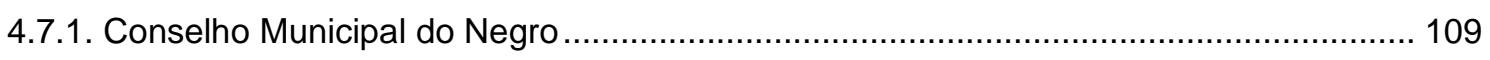

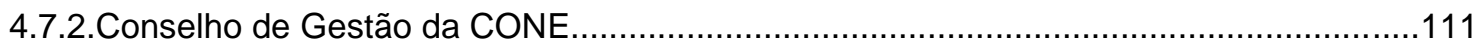

4.8. Política de Saúde Pública da População Negra no município de São Paulo ...................... 113

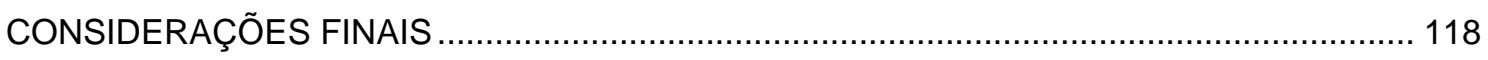

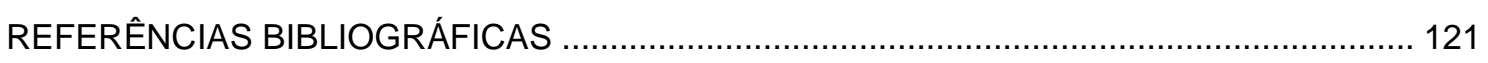




\section{INTRODUÇÃO}

Um dos objetivos do nosso trabalho é o de enfatizar a ideia de que o direito à saúde da mulher negra no Brasil não estava escrito no passado histórico do país, nem se deveu a um súbito interesse das classes mais abastadas ou do Poder Público, mas foi o resultado de um processo cuja dinâmica e atores merece atenção.

Ressaltamos também que não se trata de um estudo especulativo sobre o que teria acontecido se a população feminina negra brasileira tivesse recebido um tratamento humanizado e digno desde o período colonial e não o que realmente ocorreu.

Trata-se de estudar o desenvolvimento da noção de direito fundamental à saúde da mulher negra em São Paulo com as ações, omissões, atores sociais e a realidade do atendimento.

Para este trabalho nos fundamentamos em grande medida na doutrina de Direitos Humanos, passando pelo Direito Constitucional, a apresentação do Direito Sanitário e o tema das Políticas Públicas.

Também nos apoiamos nas publicações de organizações não governamentais de mulheres negras: Instituto da Mulher Negra- Geledés e CRIOLA.

Há espaço para nossas reflexões trazidas da nossa formação de Promotora Legal Popular da União de Mulheres de São Paulo, da nossa experiência de capacitação no Projeto Piloto Direito à Saúde da Mulher Negra (Conectas Direitos Humanos) e da nossa atuação no Conselho Gestor de Unidade Básica de Saúde na Zona Leste de São Paulo.

Passemos agora ao formato que demos a esta pesquisa. 
No capítulo primeiro destacamos os direitos humanos, os direitos fundamentais, sua história e natureza.

No capítulo segundo analisamos a constitucionalização do Direito à Saúde e a disciplina do Direito Sanitário no Brasil.

Por fim, procuramos estabelecer as relações entre os direitos da mulher e as políticas públicas de saúde e de igualdade racial e veicular a nossa proposta de Educação para Direitos Humanos como diferencial para a promoção da saúde integral da mulher negra paulistana. 


\section{CAPÍTULO I - DOS DIREITOS FUNDAMENTAIS}

\subsection{DIREITOS HUMANOS E DIREITOS FUNDAMENTAIS}

\subsection{NATUREZA E HISTÓRICO}

As religiões, a condição humana, a cultura e as conquistas históricas ${ }^{1}$ são apontadas por doutrinadores ${ }^{2}$ como fundamentos dos direitos humanos ${ }^{3}$. Em todas essas possíveis construções teóricas podemos verificar que a igualdade e a dignidade da pessoa humana são imutáveis.

Os vocábulos direitos fundamentais e direitos humanos tratam de realidades muito semelhantes.

$\mathrm{Na}$ Inglaterra medieval temos o estabelecimento de normas antecedentes das futuras Declarações de Direitos (Magna Carta da Inglaterra de 1215), Petition of Rights (1628), Habeas Corpus Amendment Act (1679) e o Bill of Rights (1688). Tais documentos, a despeito de veicularem normas pertinentes à uma classe social específica, representaram o nascedouro de regras costumeiras protetivas dos direitos humanos fundamentais. ${ }^{4}$

O termo direitos fundamentais surgiu no século XVIII estampado na Declaração Norte-Americana (1776) e na França no movimento político e cultural originário da Revolução Francesa e da Declaração dos Direitos do Homem e do

\footnotetext{
${ }^{1}$ BOBBIO, Norberto. A era dos direitos. Rio de Janeiro: Elsevier, 2004, p. 25-26 A Humanidade construiu, com avanços e retrocessos, a noção de direito. Os direitos não são conquistas homogêneas e imediatas.

${ }^{2}$ A leitura de Robert Alexy da fase final do idealismo de Kant apresenta a distinção entre os Direitos Humanos e os Direitos Fundamentais.

${ }^{3}$ Um dos pilares teóricos para o nosso histórico dos direitos humanos é a obra de Fábio Konder Comparato. Vide COMPARATO, Fábio Konder. A afirmação histórica dos direitos humanos. São Paulo: Saraiva, 2010.7.ed.rev. e atual.

${ }^{4}$ SILVA, José Afonso da. Curso de Direito Constitucional Positivo. 24a edição, 2005, Malheiros Editores, p.152.
} 
Cidadão de 1789. A despeito da controvérsia acerca da diferença entre os direitos humanos e os direitos fundamentais, as duas expressões abarcam a liberdade e a igualdade para a proteção e promoção da dignidade da pessoa humana.

\subsubsection{Noção de dignidade humana}

A dignidade da pessoa humana é 0 núcleo axiológico $^{5}$ do neoconstitucionalismo ${ }^{6}$ e um dos fundamentos do Estado Brasileiro ${ }^{7}$. É a dignidade o valor superior que orientará a criação, a interpretação e a aplicação de todo o ordenamento jurídico.

O reconhecimento e a proteção da dignidade da pessoa humana nas Constituições ocidentais aumentou consideravelmente após a Segunda Guerra Mundial, uma reação às práticas ocorridas durante o nazismo e o fascismo e contra a violação da dignidade praticada pelos regimes totalitários no planeta.

A dignidade humana está expressa em um grande número de Declarações de Direitos e Constituições e passa de um valor moral para se transformar em um valor jurídico dotado de exigibilidade e normatividade ${ }^{8}$.

A consagração da dignidade humana nos textos internacionais e nas Constituições reconhece que a pessoa é a finalidade da ordem jurídica, não é um objeto na relação com o Estado. O Estado existe para o ser humano. A dignidade humana na condição de fundamento do Estado Brasileiro exige o reconhecimento

\footnotetext{
${ }^{5}$ Sobre teoria da justiça e axiologia, vale lembrar de Miguel Reale ( Lições preliminares de Direito)

${ }^{6}$ Neoconstitucionalismo, pós-positivismo ou neopositivismo são expressões sinônimas que designam o fenômeno jurídico que destaca os valores e princípios em detrimento das regras e a proteção e promoção da dignidade da pessoa humana. Nesse sentido, as doutrinas de Robert Alexy ( Teoria dos direitos fundamentais) e Ronald Dworkin (Levando os direitos a sério). No Brasil, Daniel Sarmento, Luís Roberto Barroso dentre outros.

7 SARLET, Ingo Wolfgang. Dignidade da pessoa humana e direitos fundamentais na Constituição Federal de 1988. 5. Ed. rev. Atual - Porto Alegre: Livraria do Advogado, Ed., 2007, p. 79-82.

8 SARLET, Ingo Wolfgang. Dignidade da pessoa humana e direitos fundamentais na Constituição Federal de 1988, p. 112-113.
} 
de que o indivíduo é o valor do Conteúdo da Constituição e de toda a ordem jurídica. Ao criar, interpretar e aplicar normas jurídicas a dignidade humana deve ser promovida e respeitada.

A dignidade da pessoa humana é um dos fundamentos da República Federativa do Brasil e é valor informador dos demais valores constitucionalmente reconhecidos no texto constitucional.

No reconhecimento da dignidade humana o legislador constituinte limitou o Poder Público a observar, proteger e promover os instrumentos e mecanismos indispensáveis a vida digna e ao desenvolvimento pleno da personalidade.

Observar no sentido de que os poderes públicos devem se abster de prejudicar a dignidade humana. Proteger implica em uma ação positiva por parte dos Poderes Públicos, uma defesa da dignidade contra qualquer violação material ou imaterial.

Do valor dignidade humana decorrem dois mandamentos diferentes: o primeiro é o dever estatal aplicar todo o empenho para promoção do acesso à vida digna. Ao Estado também caberá o impedimento de todo e qualquer tipo de violação da dignidade humana, do próprio ente estatal ou de particulares ${ }^{9}$.

Cabe destacar duas correntes de pensamento das quais a dignidade humana retira a sua essência: a tradição religiosa, em especial, a cristã e a filosofia de Kant.

Alguns elementos da dignidade humana foram formulados na Escola Estoicista. O estoicismo aliou a unidade moral à dignidade do ser humano.

O cristianismo vinculou a ideia de criação e da ação divina ao conceito de ser humano, feito à imagem e semelhança de Deus.

\footnotetext{
${ }^{9}$ Sobre a natureza dúplice das normas veiculadoras de direitos fundamentais, ver ALEXY, Robert. Teoria dos direitos fundamentais. Tradução de Virgílio Afonso da Silva. Malheiros Editores, São Paulo, 2008, p.141-148.
} 
Nos séculos XVII e XVIII, os pensadores racionalistas reconheceram a dignidade humana no plano abstrato. A mudança de paradigma do fundamento do Direito Natural - de direito divino para direito racional, enraizado na experiência e na razão humana - a definição de dignidade humana foi racionalizada e laicizada preservando a igualdade dos seres humanos em dignidade. O lluminismo foi um dos movimentos cruciais para essa transformação, pois colocou o ser humano no centro da organização social. Kant afirmou que o homem é fim e não meio.

\subsubsection{Direitos Humanos e Igualdade}

No que tange à igualdade, afirma-se que os direitos humanos são de titularidade de todos os indivíduos pela singela constatação de serem humanos. A chamada igualdade pode guardar a sua gênese:

- na concepção de uma criação comum, segundo as várias expressões religiosas;

- nas características humanas presentes em todas as pessoas, consoante o pensamento da corrente naturalista de direitos humanos, ou seja, direitos humanos são direitos naturais e

- na positivação e aceitação de um rol de direitos, conforme aponta a corrente historicista de direitos humanos, portanto, o direito é uma construção que se desenvolve ao lado dos acontecimentos históricos.

A igualdade nos estudos de direitos humanos está vinculada à dignidade. Sob esse vínculo o reconhecimento de diferenças de gênero e raça é permitido sob a perspectiva de que somos todos semelhantes em nossa condição humana.

Os direitos humanos assim considerados surgiram no plano internacional no século XIX, o período do fortalecimento das soberanias e das noções de 
humanidade. Outro tema relevante do século XIX que contribuiu para os primeiros debates acerca dos Direitos Humanos foi a exploração do trabalho e a redução à escravidão das pessoas negras africanas. A reificação de outros seres humanos foi considerada uma instituição incompatível com a modernidade. Contudo, há necessidade de uma contextualização, de um olhar sensível sobre o nosso passado histórico e o tratamento designado às questões das mulheres e dos negros ${ }^{10}$.

A diversidade e a multiplicidade são características da essência humana também contempladas na Declaração Universal dos Direitos Humanos de $1948^{11}$. A Declaração tem grande importância no plano internacional, pois tem um enfoque multidisciplinar e representa a mudança do paradigma da "Paz de Westfália". No lugar das normas de respeito à soberania estatal, a Declaração está preocupada com o bem estar das pessoas no plano interno das nações.

$\mathrm{Na}$ lição de Charles Taylor ${ }^{12}$ "as leis tem de ser vistas como reflexo e defesa de sua dignidade como cidadãos, ser por conseguinte, num certo sentido, extensões deles mesmos", podemos vislumbrar que não é possível existir um ser humano digno do ponto de vista da legalidade se não houver respeito à sua essência.

A temática dos direitos humanos trata dos talentos de cada pessoa humana como parte dos recursos mantidos conjuntamente em benefício da sociedade como um todo e traz em si o pressuposto de um alto grau de solidariedade entre os indivíduos.

A Declaração não é a soma de documentos oficiais ou particulares elaborados pelas autoridades nacionais. Em realidade, esse documento inaugura

\footnotetext{
${ }^{10}$ Capítulos específicos da nossa pesquisa tratarão das questões de gênero e raça/etnia com mais detalhamento.

${ }_{11}$ ONU, Declaração Universal dos Direitos Humanos. Disponível em: http://portal.mj.gov.br/sedh/ct/legis_intern/ddh_bib_inter_universal.htm

12 TAYLOR, Charles (2000). "Propósitos entrelaçados: o debate liberal-comunitário". In: Taylor, Charles. Argumentos filosóficos. São Paulo: Loyola, p.197-220.
} 
uma tutela que só pode ser compreendida no âmbito do Direito. Sua natureza jurídica é de direito costumeiro internacional consolidado. Em face de sua qualidade de vis diretiva redundou em um conjunto de textos de positivação no sentido de generalização e especialização dos direitos humanos. Generalização, pois a dignidade humana é a razão primeira de todo e qualquer ordenamento jurídico nacional.

E especialização sob o vetor de que grupos específicos sejam reconhecidos em suas peculiaridades para o exercício pleno de sua cidadania.

Para Cançado Trindade: "Os direitos fundamentais são inerentes a toda pessoa humana, são portanto, anteriores e superiores a qualquer forma de organização política e sua salvaguarda não se esgota assim na ação do Estado ${ }^{13}$.

Direitos fundamentais são dotados de historicidade. Direitos nascem, sofrem modificações e perecem ${ }^{14}$.

Inalienabilidade, assim, direitos fundamentais são inalienáveis, inegociáveis e indisponíveis. $^{15}$

Imprescritibilidade: para o exercício dos direitos fundamentais não há falar-se em prescrição, logo, exigíveis a qualquer tempo. ${ }^{16}$

\subsubsection{Direitos Humanos e Direitos Fundamentais}

Há necessidade da diferenciação entre direitos humanos e direitos fundamentais. Direitos humanos são as normas de direito internacional que fazem menção ao ser humano, válidos para todos os seres humanos, em todos os tempos

\footnotetext{
13 TRINDADE, Antonio Augusto Cançado. A Proteção Internacional dos Direitos Humanos. São Paulo: Saraiva, 1991.

${ }^{14}$ SILVA, José Afonso da. Direito Constitucional positivo, p.181.

${ }^{15}$ SILVA, José Afonso da. Direito Constitucional positivo, p.181.

${ }^{16}$ SILVA, José Afonso da. Direito Constitucional positivo, P.181.
} 
e lugares, de caráter supranacional. Os direitos fundamentais, por sua vez, são os direitos da pessoa humana reconhecidos e positivados, vigentes de modo objetivo numa ordem jurídica concreta ${ }^{17}$.

Assim, os direitos humanos podem ser entendidos como um conjunto mínimo de direitos necessários para uma determinada finalidade: a vida humana concretizada na dignidade, na liberdade e na igualdade. Os direitos humanos nascem aos poucos e ao longo do tempo, como afirma Norberto Bobbio ${ }^{18}$.

Uma das características dos direitos humanos é sua amplitude ou abertura. $\bigcirc$ rol desses direitos é indeterminado para que a dignidade humana receba novas interpretações e projeções, sempre em caráter ampliativo, jamais restritivo, para diferentes tempos e lugares.

A segunda característica dos direitos humanos é a reflexão. Direitos humanos são dotados de essencialidade, ou seja, nem todos os direitos são essenciais, fundamentais para a pessoa humana e para o exercício de outras prerrogativas.

Por fim, outra qualidade é a dignidade. É a dignidade que assegura a vida do ser humano. A dignidade tem uma recomendação negativa porque veda 0 tratamento degradante e uma indicação positiva, qual seja, a afirmação da proteção dos direitos humanos.

O tema direitos humanos qualifica o que é mais crítico em qualquer ordem jurídica. Na lição de José Afonso da Silva"19: "a dignidade humana é o epicentro axiológico da Constituição Brasileira, a lei máxima do Estado, de todo o

\footnotetext{
${ }^{17}$ CANOTILHO, J.J.Gomes. Direito Constitucional e Teoria da Constituição, $7^{\mathrm{a}}$ ed., Coimbra, Almedina.

${ }^{18}$ BOBBIO, Norberto. Era dos Direitos, tradução Carlos Nelson Coutinho, Rio de Janeiro, Campus, 1988.

${ }^{19}$ SILVA, José Afonso da. A dignidade da pessoa humana como valor supremo da democracia. Revista de Direito Administrativo. Rio de Janeiro: volume 212, abril e junho de 1998.
} 
ordenamento jurídico brasileiro, pois todas as normas tem sua base na constituição."

Falar em "geração" pode parecer que uma "onda" de direitos supera a anterior. No entanto, Flávia Piovesan pondera que

uma geração de direitos não substitui a outra, mas com ela interage. Isto é, afasta-se a equivocada ideia da sucessão 'geracional' de direitos, na medida em que se acolhe a ideia da expansão, cumulação e fortalecimento dos direitos humanos, todos essencialmente complementares e em constante dinâmica de interação. Logo, apresentando os direitos humanos uma unidade indivisível, revela-se esvaziado o direito à liberdade quando não assegurado o direito à igualdade e, por sua vez, esvaziado revela-se o direito à igualdade quando não assegurada a liberdade. ${ }^{20}$

É a ideia consagrada no artigo $5^{\circ}$ da Declaração de Viena de 1993: "todos os direitos humanos são universais, indivisíveis interdependentes e inter-relacionados".

Os direitos humanos de primeira geração limitam o poder estatal com o fito de preservar as liberdades individuais, implicando nos deveres de não ingerência, não intromissão, não repressão e não censura. Abarcam as liberdades negativas.

A segunda geração de direitos humanos ${ }^{21}$ busca a igualdade e vê o cidadão com um ser social que exige do Estado ações em defesa de sua dignidade na forma de realizações de políticas e serviços públicos. A saúde é um direito humano de segunda geração. Os direitos de segunda geração, também chamados prestacionais, são caracterizados por um caráter positivo, ao Estado cabe o dever de agir. Os poderes públicos e seus agentes devem realizar uma série de práticas positivas visando a proteção, a promoção ou a garantia das condições de fruição de determinados bens jurídicos. Essas prestações podem ser materiais ou jurídicas. Os

\footnotetext{
${ }^{20}$ PIOVESAN, Flávia. Direitos Humanos e o Direito Constitucional Internacional, Segunda Parte, Cap. V, d. São Paulo, Max Limonad.

${ }^{21}$ A Constituição mexicana de 1917 e a Constituição da República de Weimar (1919) são exemplos históricos do reconhecimento dos direitos econômicos e sociais, de segunda geração.
} 
direitos de participação asseguram a participação individual na construção da vontade política da coletividade. Ensina Carlos Weiss ${ }^{22}$ que os direitos de segunda geração exigem a intervenção do Poder Público para equilibrar as condições materiais de existência. São direitos participativos que requerem uma política pública, destinada a garantir o efetivo exercício daqueles, e que se efetivam através dos serviços públicos.

A indivisibilidade é a marca da terceira geração de direitos humanos ${ }^{23}$. Os titulares dos direitos de fraternidade são os sindicatos, os condomínios, as associações e as organizações não governamentais. Os direitos difusos ao meio ambiente ecologicamente equilibrado, à comunicação correspondente à verdade e a propriedade sobre o patrimônio comum da humanidade para a geração presente e as gerações vindouras são exemplos de direitos humanos de terceira geração. 0 fenômeno da globalização ${ }^{24}$ que caracterizou o final do século XX e está presente

\footnotetext{
${ }^{22}$ WEISS, Carlos. Direitos Humanos Contemporâneos, Cap. 2, item 1.

${ }^{23}$ Direitos de terceira geração também denominados direitos de solidariedade pois caracterizados pela heterogeneidade e titularidade de natureza coletiva.

${ }^{24} \mathrm{~A}$ globalização ampliou o contato entre a política, a economia e a cultura dos povos e redundou na criação de direitos humanos e deveres estatais que rompem as tradicionais fronteiras nacionais e a noção de soberania. Entretanto é necessária a advertência de que a dinâmica das relações internacionais remonta a tempos imemoriais e que o progresso tecnológico do final do século XX e início do século XXI exigiu uma atenção e uma nomenclatura especial por parte dos especialistas. Para esclarecimentos sobre a ordem mundial e a ordem internacional vide BULL, Hedley. $A$ sociedade anárquica Universidade de Brasilia, Instituto de Pesquisa de Relações Internacionais, São Paulo, Imprensa Oficial do Estado, 2002,p. 7-29. Sobre a sociedade em rede e o Estado global, examinar: CASTELLS, Manuel. A Crise da Democracia, Governança Global e a Emergência de uma Sociedade Civil Global. In: Por uma Governança Global Democrática (vários autores). São Paulo: Instituto Fernando Henrique Cardoso, 2005. Sobre globalização e exclusão social, Milton Santos apresenta os contrastes da globalização por todo o mundo: " $A$ fome deixa de ser um fato isolado ou ocasional e passa a ser um dado generalizado e permanente. Ela atinge 800 milhões de pessoas espalhadas por todos os continentes. Quando os progressos da medicina e da informação deviam autorizar uma redução substancial dos problemas de saúde, sabemos que 14 milhões de pessoas morrem todos os dias, antes do quinto ano de vida.

Dois bilhões de pessoas sobrevivem sem água potável (...) O fenômeno dos sem-teto, curiosamente na primeira metade do século $X X$, hoje é um fato banal, presente em todas as grandes cidades do mundo. O desemprego é algo tornado comum. (...) A pobreza também aumenta. No fim do século XX havia mais 600 milhões de pobres do que em 1960; e 1,4 bilhão de pessoas ganham menos de um dólar por dia. (...) O fato, porém, é que a pobreza, tanto quanto o desemprego, são considerados como algo "natural", inerente a seu próprio processo. Junto ao desemprego e à pobreza absoluta, registre-se o empobrecimento relativo de camadas cada vez maiores graças à deterioração do valor do trabalho." SANTOS, Milton. Por uma outra globalização: do pensamento único à consciência universal. Rio de Janeiro, Record, 2000, p.59.
} 
no XXI desenvolveu a coletivização dos conflitos e a preocupação premente em proteger a condição humana no plano individual e no contexto das coletividades de pessoas determinadas ou indeterminadas. Destinados à proteção da espécie humana são chamados direitos transindividuais ${ }^{25}$.

Os direitos humanos de quarta geração abrangem os direitos à democracia, à informação e ao pluralismo segundo Bonavides ${ }^{26}$. No magistério de Celso Lafer, "os direitos de terceira e quarta gerações transcendem a esfera dos indivíduos considerados em sua expressão singular. "27

$\mathrm{Na}$ forma proposta por Comparato eis o fundamento dos direitos humanos: “...) a dignidade de cada homem consiste em ser, essencialmente, uma pessoa, isto é, um ser cujo valor ético é superior a todos os demais no mundo."28

Para Comparato, o ser humano é dotado de algumas características particulares, definidoras da sua especificidade e basilares da sua dignidade: a liberdade, a autoconsciência, a sociabilidade, a historicidade e a unicidade existencial humana.

Liberdade, pois o ser humano é singular em possuir a capacidade de agir sem a condução dos instintos. É no âmbito da liberdade que observamos a ética, as opções valorativas. A autonomia do ser humano guarda o seu nascedouro na liberdade, uma vez que é a capacidade de estabelecer as suas próprias normas de conduta ${ }^{29}$

\footnotetext{
${ }^{25}$ Direitos fundamentais de quarta dimensão para Paulo Bonavides tem relação com a "globalização política neoliberal”. BONAVIDES, Paulo. Curso de Direito Constitucional. 19a Edição, São Paulo : Editora Malheiros, 2006, p. 571-572.

${ }^{26}$ BONAVIDES, Paulo. Op.cit.

${ }^{27}$ apud, Alexandre de Moraes, Direitos Humanos Fundamentais, Parte I, n. 11.São Paulo, Editora Atlas.

${ }_{28}$ COMPARATO, Fábio Konder. Fundamento dos Direitos Humanos. Texto disponível em: http://iea.usp.br/artigos.p.28.

${ }^{29}$ COMPARATO, Fábio Konder. Op.cit. p.22.
} 
Autoconsciência, oposta à alienação, uma vez que o ser humano além de possuir memória, tem consciência de ser sujeito no tempo e no espaço e além, de sua mortalidade. Comparato apresenta dois conceitos de alienação. O primeiro de Feuerbach, "negativa da especificidade" e o de Marx que aplicou o conceito para a classe operária que, liberta da alienação, humanizaria as relações de trabalho e produção.

O indivíduo humano desenvolve a sua porção pessoa em sociedade, daí decorre a característica da sociabilidade. As capacidades de produzir cultura e de autoaperfeiçoamento são apreendidas e desenvolvidas no meio social.

O ser humano vive em contínua transformação, entre lembranças do passado e planejamento dos eventos futuros. A experiência humana é construída no desenrolar histórico, passando por diversas épocas e sociedades, daí decorre a historicidade.

Todos os seres humanos e cada um de nós é um ser único e impassível de substituições. Essa característica de unicidade, originária do cristianismo, foi confirmada pela Biologia que afirmou a singular combinação genética recebida de nossos genitores. O ser humano é impassível de troca, é insubstituível. Sob outro prisma, a dignidade reside na habilidade de formular as suas próprias normas (autonomia).

Para o nosso estudo em particular, significativas as ponderações de Eunice Aparecida de Jesus Prudente, que em sua Dissertação de Mestrado "Preconceito Racial e Igualdade Jurídica no Brasil”, apresenta a problemática do negro brasileiro e a contraditória lógica da História: pseudo-humanidade no período escravagista e liberdade marginal após a "Abolição" inconclusa. Em paráfrase: o Estado Brasileiro desenvolveu-se na temática dos Direitos Humanos, no entanto, as violações da 
dignidade humana de homens e mulheres negros continuam. Assim vejamos, no regime da escravatura não havia a previsão e o reconhecimento de direitos, uma vez que pessoas escravizadas não eram cidadãs. O Direito Civil considerava a mulher negra e o homem negro na categoria de semoventes, o que redundava na vedação de constituição de entidade familiar negra, quadro bem diverso dos grupos imigrantes de origem europeia e asiática. A legislação penal para o negro escravizado destoava dos ares liberais da época e previa pena capital sem a possibilidade de recurso judicial.

Série considerável de restrições cívicas foram impostas aos negros libertos, além da marginalização imposta pelo sufrágio censitário, havia também a vedação expressa ao exercício de voto nas eleições dos deputados, senadores e membros dos Conselhos de Província ${ }^{30}$.

A desigualdade racial consolidou-se no Brasil, formando uma sociedade segmentada e estratificada em função do tom de pele. Sob o manto da "democracia racial", havia a valorização da igualdade jurídica em uma nação desigual. O termo "democracia racial" ganha força na obra de Gilberto Freyre na década de 1950. Baseada em uma visão amenizada do passado de escravização de mulheres e homens negros, a democracia racial apresentou um cenário de paz e tolerância. Em outras palavras, uma convivência pacífica pela proximidade física, cultural e geográfica. As teses da democracia racial foram alvo de questionamento por pesquisadores ligados a Florestan Fernandes. E a partir dos anos 1980, estudos publicados por instâncias governamentais e organizações da sociedade civil

\footnotetext{
30 PRUDENTE, Eunice Aparecida de Jesus. Preconceito racial e igualdade jurídica no Brasil. (Dissertação/Mestrado), Faculdade de Direito da Universidade de São Paulo. p. 243-244.
} 
demonstrando a pobreza e as oportunidades reduzidas da população negra, obrigaram o Estado brasileiro a reconhecer o racismo existente ${ }^{31}$.

Conclui Eunice Prudente que o Estado Brasileiro encampou o bem comum, portanto, deve lançar mão dos instrumentos jurídicos (em nosso sentir, políticas públicas) para a prevalência do interesse social e do respeito à dignidade humana, enfim, a promoção da real imagem e contribuição das mulheres e dos homens negros à nossa sociedade.

\subsection{DIREITOS E GARANTIAS FUNDAMENTAIS}

Os direitos humanos diferem dos direitos fundamentais, os últimos estão positivados no corpo da Constituição. Um dos fundamentos do Estado brasileiro é a dignidade da pessoa humana (artigo 1ํ, inciso III, CF). É valor-fonte e suas irradiações são os direitos humanos constitucionalmente insculpidos. A dignidade não pode ser confundida com um direito fundamental, em realidade é um atributo inerente à essência humana. Entretanto, vislumbramos uma relação de dependência recíproca entre o valor/atributo dignidade e os direitos fundamentais. Os valores mais importantes da convivência humana são identificados nos direitos humanos; sem eles as sociedades recaem em um processo desagregador irreversível ${ }^{32}$.

Os direitos fundamentais são uma decorrência da dignidade porque promovem o pleno desenvolvimento da pessoa humana e a previsão legislativa e o

\footnotetext{
${ }^{31}$ As políticas públicas e a desigualdade racial no Brasil: 120 anos após a abolição / Mário Theodoro (org.), Luciana Jaccoud, Rafael Osório, Sergei Soares . - Brasília: Ipea, 2008.176 p. : gráfs., tabs.

${ }^{32}$ COMPARATO, Fábio Konder. A afirmação histórica dos direitos humanos. $3^{a}$ ed.São Paulo: Saraiva, 2004 , p.26.
} 
cumprimento desses direitos constituem a materialização do valor dignidade humana.

As garantias fundamentais são instrumentos de proteção dos direitos fundamentais. Munidos das garantias os cidadãos tem afirmam os seus direitos fundamentais em face de ameaças e violações do Estado e/ou terceiros.

Nosso direito constitucional brasileiro adota como critérios de classificação dos direitos fundamentais o conteúdo, a natureza do bem tutelado e o objeto de proteção. O legislador constituinte afirma que os direitos e garantias fundamentais podem ser expressos ou consequências dos tratados e convenções internacionais ratificados pelo Brasil (artigo $5^{\circ}, \S 2^{\circ}$ ).

Segundo José Afonso da Silva, os direitos fundamentais decorrentes dos tratados e convenções internacionais são extraídos do regime democrático, da participação popular direta e do pluralismo político. ${ }^{33}$

Os direitos fundamentais da população negra, em especial a feminina, estão formalmente previstos em nosso texto constitucional. Neste trabalho analisaremos com mais cuidado a questão do direito fundamental à saúde da mulher negra no município de São Paulo. Em um primeiro momento, será apresentado o conceito de direito à saúde e traçado o seu panorama jurídico no Brasil. Posteriormente, cuidaremos especificamente da política pública de saúde nacional, do Estado de São Paulo e de sua capital.

${ }^{33}$ SILVA, José Afonso. Curso de Direito Constitucional positivo. p.182-184 


\section{CAPÍTULO II - O DIREITO FUNDAMENTAL À SAÚDE NO BRASIL}

\section{1. $O$ direito à saúde e o direito sanitário}

As políticas públicas de saúde ${ }^{34}$ dependem dos valores éticos de cada civilização em seu momento histórico, do valor ético da definição de ser humano e do próprio significado do conceito de saúde.

A política pública de saúde tem como princípio a proteção de um bem relevante para o conjunto social. $\mathrm{O}$ conceito de saúde pública remonta à consolidação do Estado Moderno no período da Renascença. As cidades europeias, preocupadas com os cuidados aos doentes pobres, aumentaram as medidas de higiene após as lições das doenças epidêmicas da Idade Média. O período iluminista amplificou a ideia do dever do Estado de controle do exercício da medicina e da farmácia e a repressão às práticas de charlatanismo.

O lluminismo ao utilizar o método científico para descrever enfermidades e aplicar tratamentos, atribuiu à medicina uma relevância ímpar, fato que explica a regulamentação e o controle do Estado sobre o exercício da ciência médica.

O pensamento iluminista ao defender a necessidade de planejamento das atividades estatais, aliada à crescente afirmação dos direitos naturais do homem, ensejou a realização de medidas de saneamento básico, por exemplo, drenagens de áreas pantanosas e abertura de canais, impedindo a proliferação de doenças. $\mathrm{O}$ conceito contemporâneo de saúde pública adquire contornos definidos no Estado

\footnotetext{
${ }^{34}$ Os temas política pública e política pública de saúde serão contemplados em momentos específicos em nosso trabalho.
} 
liberal da segunda metade do século dezoito. O envolvimento do Estado na assistência social e no atendimento à saúde era considerado subsidiário do espírito solidário da comunidade. Essa atuação secundária da organização estatal viria a ser a gênese do serviço público de saúde. Sueli Gandolfi Dallari faz referência à França que instaura a assistência à saúde como serviço público no período da Restauração ${ }^{35}$.

O Estado liberal concede proteção constitucional à saúde. Durante a Restauração francesa surgiu a primeira legislação sobre a higiene urbana, o conceito legal de insalubridade e o controle sanitário nas regiões fronteiriças. A atuação do Estado liberal burguês veiculou os interesses da classe social ascendente: controle das atividades profissionais e de ensino médico e farmacêutico, organização e administração hospitalar pelas comunas, ambas sob os signos do antropocentrismo e do individualismo.

A saúde pública como prioridade política é fenômeno da segunda metade do século dezenove. Pesquisas científicas atestam a ligação direta entre a saúde e as condições de vida datam dessa época. A proteção da saúde dos grupos sociais mais carentes passou a ser uma finalidade estatal e uma arma contra a pobreza, fator de ameaça à organização do Estado e à ordem pública. O conceito de prevenção, antes restrito às associações, é propagado nesse ambiente favorável como uma finalidade dúplice: política e social. A procura dos primeiros sinais de doença e posteriormente a vacinação proporcionam uma revolução na prevenção das enfermidades, uma vez que evitar a contaminação é medida preventiva por natureza. Comitês de Vacinação são criados e do ponto de vista das autoridades políticas a ameaça das doenças prepondera aos riscos da enfermidade em si,

${ }^{35}$ GANDOLFI, Sueli Dallari. Direito Sanitário. Curso de Especialização a Distância em Direito Sanitário para membros do Ministério Público e da Magistratura Federal.p.43. 
ocorre a superação da perspectiva individual para uma preocupação coletiva, primordialmente através da publicidade das ferramentas estatísticas na avaliação da saúde.

As primeiras décadas do século vinte instauram a proteção sanitária como política de Estado. E é criada a hierarquia de três formas de prevenção em saúde ${ }^{36}$ : a prevenção primária, que objetiva a eliminação das causas e condições de surgimento de moléstias, atuando sobre o ambiente (exemplos: segurança nas ruas e estradas e programas de saneamento básico) ou sobre os comportamentos dos indivíduos ( exemplos: promoção de exercícios físicos e alimentação saudável) e a secundária ou prevenção específica, que almeja evitar o aparecimento de determinada doença, fazendo uso da vacinação, dos controles de saúde, da despistagem ${ }^{37}$; e a prevenção terciária, que procura reduzir os prejuízos das incapacidades crônicas e as reincidências.

O Estado do Bem-Estar Social da segunda metade do século vinte incentivou a lógica da Economia, principalmente em face da interdependência óbvia entre as condições de saúde e de trabalho, e implementou medidas de prevenção sanitária. Os sistemas de previdência social são estruturados e ao lado do cuidado das pessoas enfermas instituem a prevenção sanitária. De início, esses sistemas estabeleciam a priori uma distinção entre a assistência social (dirigida às classes mais carentes, calcada no princípio da solidariedade e suportada por recursos públicos estatais - e a previdência social, um instrumento de segurança financeira restrito aos trabalhadores).

A prevenção em saúde era uma das finalidades do Estado e de seu desenvolvimento, portanto, se consolida o conceito de seguridade social, que

${ }^{36}$ DALLARI, Sueli Gandolfi. Direito Sanitário. Curso de Especialização a Distância em Direito Sanitário para membros do Ministério Público e da Magistratura Federal.p.44.

${ }^{37}$ Despistagem é a realização de testes para encontrar sinais de doença ainda não detectada. 
engloba as áreas de assistência social, previdência social e saúde pública. As últimas décadas do século vinte, não obstante, descortinam uma nova visão da saúde pública, muito impactada pela insatisfação com os impactos sociais das políticas públicas preventivas que não eliminaram a exclusão social nem obtiveram êxito no campo da saúde pois desconsideraram o papel das atitudes individuais na prevenção e tratamento de doenças ${ }^{38}$. Concomitantemente, a ideologia neoliberal gerou a diminuição do papel do Estado na sociedade e o crescimento dos grupos, associações e da responsabilidade pessoal. A organização e a evolução dos cuidados relativos à AIDS (síndrome da imunodeficiência adquirida) em boa parte das nações ocidentais - é amostra dessa nova concepção de saúde. Dessa maneira, preponderou a disciplina de que a prevenção de doenças é um dever individual e que os grupos - de doentes ou de portadores do vírus HIV (vírus da imunodeficiência humana) ou de familiares ou amigos - são capazes e habilitados para orientar a prestação do serviço público de saúde. De modo subsidiário, o Poder Executivo é o responsável por controlar a qualidade do sangue e seus derivados, fator importante na prevenção da síndrome da imunodeficiência adquirida. Há uma supervalorização das ações e omissões individuais em detrimento do exame das estruturas econômicas e sociais.

Assim, o quadro apresentado é de estruturas estatais de prevenção e cuidado da saúde que fazem suas escolhas após o exame da relação econômica custo/benefício e não mais em razão dos fatores epidemiológicos. Essa priorização do aspecto econômico explica o pouco ou nenhum investimento nas etapas de prevenção em saúde.

\footnotetext{
${ }^{38}$ DALLARI, Sueli Gandolfi. Direito Sanitário. Curso de Especialização a Distância em Direito Sanitário para membros do Ministério Público e da Magistratura Federal.p.44
} 
No Brasil merece destaque o arrojo de pesquisadores do direito sanitário que implantaram a disciplina na Universidade de São Paulo (USP) a partir do final dos anos 1980. Um curso de especialização em direito sanitário foi criado no ano de 1989. A Universidade de São Paulo, por ocasião da reforma de seus Estatutos criou um Núcleo de Pesquisas em Direito Sanitário (NAP-DISA) para a reunião de profissionais especialistas de um ou mais órgãos e Unidades em torno de programas de pesquisa ou pós-graduação interdisciplinares em Direito e Saúde Pública ${ }^{39}$.

\subsection{A constitucionalização do Direito Sanitário}

O reconhecimento do direito sanitário na atual Constituição Brasileira apresenta duas características principais: o direito à saúde configurado como direito fundamental e os princípios regentes da política pública da saúde ${ }^{40}$.

A definição da saúde como direito fundamental se dá pela primeira vez na história constitucional brasileira em $1988^{41}$. A saúde integra um dos direitos sociais reconhecidos no artigo $6^{\circ}$, que abre o Capítulo II (Dos Direitos Sociais) do Título II (Dos Direitos Fundamentais) da Constituição de 1988. O caput do art. 196 define a saúde como - direito de todos e dever do Estado. A Constituição de 1988 adota explicitamente essa natureza do direito à saúde no artigo 196 que estabelece que esse direito será garantido através de políticas sociais e econômicas que objetivam à redução do risco de doenças, de outros gravames à saúde e ao acesso universal

\footnotetext{
39 DALLARI, Sueli Gandolfi. Direito Sanitário. Curso de Especialização a Distância em Direito Sanitário para membros do Ministério Público e da Magistratura Federal.p.45.

${ }^{40}$ DALLARI, Sueli Gandolfi. Direito Sanitário. Curso de Especialização a Distância em Direito Sanitário para membros do Ministério Público e da Magistratura Federal.p.52.

${ }_{41}$ MAUÉS, Antonio G. Moreira e SIMÕES, Sandro Alex de. Direito Público Sanitário Constitucional.Curso de Especialização a Distância em Direito Sanitário para membros do Ministério Público e da Magistratura Federal,p. 422.
} 
e igualitário às ações e serviços para sua promoção, proteção e recuperação. Outras normas constitucionais também exigem obrigações ao Estado na área da saúde , por exemplo o artigo 23, inciso II, estabelece como competência comum dos entes federativos o cuidado e a atenção à saúde e o artigo 24, no inciso XII, prevê a inclusão da proteção e defesa da saúde na competência concorrente a legislação sobre - proteção e defesa da saúde.

Por conseguinte, o direito à saúde ganhou status constitucional em 1988 com caráter de direito público subjetivo a prestações do Estado, a tal direito emerge o correspondente dever dos Poderes Públicos no desenvolvimento de políticas garantidoras desse direito humano fundamental. A constitucionalização é gênese para compreender a eficácia e aplicabilidade do direito à saúde.

De modo similar aos demais direitos prestacionais, o direito à saúde impõe especificidades para sua adequada efetivação.

A primeira dimensão da eficácia das normas constitucionais referentes à saúde reside em vincular o legislador nacional a elaborar as leis fundamentais para a regulamentação do tema. Logo, o legislador não possui discricionariedade no exercício dessa competência, a contrario sensu, o dever de criar a lei é enfatizado pela arquitetura constitucional de garantias, por exemplo, a ação de inconstitucionalidade por omissão e o mandado de injunção.

O direito à saúde tem força vinculante em relação aos demais Poderes Públicos que devem respeito e promoção deste direito no desempenho de suas atribuições constitucionais. São consideradas não recepcionadas as normas anteriores à Constituição contrárias à ordem constitucional sobre a saúde. A Constituição de 1988 é por si mesma o parâmetro de interpretação das outras normas jurídicas. 
Por derradeiro, o direito à saúde deve ser usado pelo Poder Judiciário no juízo de ponderação de bens e interesses para examinar a constitucionalidade da vedação ou restrição de outros direitos fundamentais. $O$ direito da saúde pública ${ }^{42}$ é parte integrante do tradicional direito administrativo ou é identificado como uma especialidade deste ramo jurídico.

É face do direito administrativo porque faz referências à atividade estatal orientada pela própria sociedade, por meio dos seus representantes nos Poderes Legislativo e Executivo. Na prática, o direito da saúde pública pode ser identificado como direito administrativo pois é disciplina jurídica caracterizada pelos princípios básicos da supremacia do interesse público sobre o privado e da indisponibilidade do interesse público.

No entanto, a associação ao direito administrativo é insuficiente, vez que no plano da aplicação o direito da saúde pública é pautado ora pelo poder de polícia, ora sob o prisma da prestação de um serviço público, e outras vezes é um híbrido dos anteriores, por exemplo, na vacinação obrigatória para proteger ou recuperar a saúde da população.

O direito sanitário tem seu foco tanto no direito à saúde, que é uma reivindicação de um direito humano, quanto no direito da saúde pública, um sistema de normas jurídicas que tem por objeto a promoção, prevenção e recuperação da saúde de todas as pessoas formadoras do povo de determinado Estado nacional. Tal direito abrange, dessa maneira, os dois os ramos tradicionais da ciência do direito: o público e o privado. Contempla também a sistematização dos debates entre ética e saúde e, com destaque, o direito internacional sanitário, a disciplina que estuda a atuação de organismos internacionais, fontes de normas de saúde

42 MAUÉS, Antonio G. Moreira e SIMÕES, Sandro Alex de. Direito Público Sanitário Constitucional.Curso de Especialização a Distância em Direito Sanitário para membros do Ministério Público e da Magistratura Federal,p. 423-425. 
pública e das muitas organizações supranacionais dedicadas à promoção e defesa dos direitos humanos.

O direito sanitário é uma disciplina de sistematização recente, contudo, a existência de leis veiculadoras da atenção à saúde são perceptíveis desde os primórdios da história humana bem como a noção de saúde como atributo humano fundamental.

Segue o conceito de direito à saúde desenvolvido por Sueli Gandolfi Dallari ${ }^{43}$, a saber: "Observado como direito individual, o direito à saúde privilegia a liberdade em sua mais ampla acepção." E sob o aspecto social do direito à saúde: "As limitações aos comportamentos humanos são postas exatamente para que todos possam usufruir igualmente as vantagens da vida em sociedade. “

O direito à saúde apresenta o equilíbrio estável entre os valores da igualdade e da liberdade ${ }^{44}$.

A Declaração Universal dos Direitos Humanos (1948) em seu artigo 25 consigna o direito de toda pessoa à saúde e ao bem estar:

1. Toda pessoa tem direito a um padrão de vida capaz de assegurar a si e a sua família saúde e bem estar, inclusive alimentação, vestuário, habitação, cuidados médicos e os serviços sociais indispensáveis, e direito à segurança em caso de desemprego, doença, invalidez, viuvez, velhice ou outros casos de perda dos meios de subsistência fora de seu controle. ${ }^{45}$

Pelo Pacto Internacional de Direitos Econômicos, Sociais e Culturais (1966) verificamos no artigo 12 o compromisso dos Estados signatários no reconhecimento do direito humano à fruição de adequado nível de saúde física e mental, abarcando ações concretas para o exercício desse direito:

\footnotetext{
${ }^{43}$ DALLARI, S. G. O direito à saúde. Rev. Saúde públ., S. Paulo, 22:57-63, 1988.

${ }^{44}$ DALLARI, S.G. O direito à saúde.Rev. Saúde púbI. S. Paulo, 22: 59, 1988.

45 Declaração Universal dos Humanos http://portal.mj.gov.br/sedh/ct/legis_intern/ddh_bib_inter_universal.htm
} 
1. Os Estados Partes do presente Pacto reconhecem o direito de toda pessoa desfrutar o mais elevado nível possível de saúde física e mental.

2. As medidas que os Estados partes do presente Pacto deverão adotar com o fim de assegurar o pleno exercício desse direito incluirão as medidas que se façam necessárias para assegurar:

a) a diminuição da mortalidade infantil, bem como o desenvolvimento são das crianças;

b) a melhoria de todos os aspectos de higiene do trabalho e do meio ambiente;

c) a prevenção e tratamento das doenças epidêmicas, endêmicas, profissionais e outras, bem como a luta contra essas doenças;

d) a criação de condições que assegurem a todos assistência médica e serviços médicos em caso de enfermidade. ${ }^{46}$

O legislador constituinte afirma que a saúde é um direito social no artigo 6ํ․ Já no artigo 7ํㅡㄹ dois incisos falam do tema: o IV (salário mínimo e necessidades básicas do trabalhador) e o XXII que determina a criação de disciplina normativa de prevenção, proteção e segurança. Isso significa que o direito à saúde foi constitucionalmente consagrado em nosso ordenamento jurídico e que para o adequado controle social é necessário o conhecimento do SUS e da legislação da saúde.

A saúde, direito fundamental brasileiro, vem assegurada na Constituição Federal de 1988 como direito de todos e dever do Estado, a ser garantido mediante a adoção de políticas públicas, com a garantia do acesso universal igualitário às ações e aos serviços em seu artigo 196:

A saúde é direito de todos e dever do Estado, garantido mediante políticas sociais e econômicas que visem à redução do risco de doença e de outros agravos e ao acesso universal igualitário às ações e serviços para sua promoção, proteção e recuperação.

No artigo 23, inciso II, a competência comum para a saúde é da União, dos Estados, do Distrito Federal e dos Municípios. Mais adiante no inciso XII do artigo 24, temos a competência concorrente para a criação de leis para a saúde. Aos

\footnotetext{
46 Pacto Internacional de Direitos Econômicos, Sociais e Culturais http://portal.mj.gov.br/sedh/ct/legis_intern/pacto_dir_economicos.htm
} 
Municípios cabe a prestação de serviços de atendimento à saúde da população, cooperando técnica e financeiramente com a União e o Estado, uma vez que a gestão da saúde no Brasil é municipalizada. Para Dallari: "A municipalização do sistema sanitário é a forma ideal de organização do setor saúde no Brasil."^7

A regulamentação, fiscalização e controle dos serviços de saúde são de execução do Estado de forma direta ou indiretamente por pessoas físicas e/ou pessoas jurídicas, conforme a disciplina do artigo 197 e as Leis n. 8080/90 e 8142/1990, regulamentadoras do Sistema Único de Saúde (SUS).

O Sistema Único de Saúde (SUS) é a política pública de saúde do país ${ }^{48}$. 0 Brasil apresenta um sistema de saúde misto, ou seja, abrange atividades estatais com financiamento público e parcerias privadas com o poder público ao lado de um sistema de assistência suplementar à saúde (Lei n 9656/1998). O SUS constitui o conjunto de ações e serviços de saúde prestados por órgãos e instituições públicas federais, estaduais e municipais. Prevê a obrigatoriedade do atendimento público a todo e qualquer cidadão. Apresenta princípios fundamentais, a saber: a universalidade, a integralidade, a descentralização, a equidade e a participação social. (artigo $7^{\circ}$ da Lei 8.80/1990).

\subsection{Princípios constitucionais do Direito Sanitário}

Observamos o crescimento da relevância dos princípios no estudo e na aplicação do Direito. Os princípios são classificados como normas jurídicas autênticas e suas prescrições vinculam os agentes estatais e os particulares. Os

\footnotetext{
${ }^{47}$ DALLARI, S.G. O direito à saúde.Rev. Saúde públ. S. Paulo, 22: 59, 1988.

${ }^{48}$ Curso de capacitação de conselheiros gestores/Secretaria Municipal de Saúde. Coordenação de Gestão de Pessoas. Diretoria de Gestão de Desenvolvimento de Pessoas. Escola Municipal de Saúde/CEFOR/ETSUS-SP. São Paulo: Secretaria da Saúde, 2011.
} 
princípios, singularmente no direito constitucional, também oferecem ordens hermenêuticas para os profissionais do Direito.

Devemos recordar a aplicabilidade de outros princípios constitucionais no âmbito do direito sanitário, tais como os relativos à administração pública (artigo 37) e os princípios gerais da ordem social (artigo 193), os princípios constitucionais da seguridade social (artigo 194) e da saúde (artigos 196 e 198)..$^{49}$

A interpretação desses artigos denota o estabelecimento de diretrizes que devem ser obedecidas pelo Poder Público na realização de seus deveres. Nesse sentido, os princípios exigem do Estado uma série de objetivos norteadores da implementação das políticas públicas, restringindo a discricionariedade. Aos profissionais do Direito, os princípios são instrumentos de verificação da constitucionalidade e legalidade materiais das políticas públicas no plano das atividades-meio e atividades-fim. O estudo dos artigos 194, 196 e 198 associado ao da Lei 8.080/90 (Lei Orgânica da Saúde - LOS), em seu artigo $7^{\circ}$, realça os seguintes princípios da política pública de saúde:

a) universalidade (artigos 194, inciso I e 196, caput): essa norma encerra a cisão que precipuamente existia entre os trabalhadores segurados do sistema de previdência social e os demais setores da população. Como direito de todas e todos, a saúde dispensa qualquer requisito para seu exercício, o acesso a equipamentos e serviços de saúde deve ser universal e igualitário - em todos os planos de assistência (artigo 7ํㅡ, I, da Lei Orgânica da Saúde- LOS). A política pública de assistência à saúde é inspirada pela igualdade, despida de preconceitos ou privilégios de qualquer natureza (artigo $7^{\circ}$, IV , da LOS). Ou seja, a garantia de atenção à saúde por parte do sistema, a todo e qualquer cidadão, sem quaisquer

49 MAUÉS, Antonio G. Moreira e SIMÕES, Sandro Alex de. Direito Público Sanitário Constitucional.Curso de Especialização a Distância em Direito Sanitário para membros do Ministério Público e da Magistratura Federal,p. 427. 
distinções. É importante reforçar que, em determinadas situações, a realização do princípio da igualdade (nesse ponto a igualdade está mais próxima da noção de equidade) pode exprimir a prestação de um atendimento prioritário de crianças, adolescentes, gestantes e pessoas com deficiências; portanto, os serviços de atenção à saúde devem adaptar-se às necessidades presentes, de maneira diferenciada conforme cada uma delas;

b) natureza democrática e descentralizada da administração, com participação comunitária (artigos 194, inciso VII e 198, incisos I e III): a descentralização é assim definida: a redistribuição das responsabilidades pelas ações e serviços de saúde entre os vários níveis governamentais, a partir da concepção de que, quanto mais próximo do fato a decisão for tomada, mais chance haverá de êxito, há um incremento do poder dos municípios na política pública de saúde. O caráter democrático e descentralizado norteia a regulamentação dos serviços de saúde ao lado da municipalização, ou seja, a maior responsabilidade dos Municípios na feitura das ações de saúde, conforme anuncia o artigo 7º, inciso IX, alínea "a", da Lei Orgânica da Saúde (LOS). Essa participação popular ocorrerá nos conselhos e nas conferências de saúde. Usuários, governo, profissionais de saúde e prestadores de serviços terão representação paritária. Todo gestor, em qualquer nível governamental, deve participar desses foros de debate em obediência à Lei ${ }^{50}$.

A composição das Conferências e dos Conselhos precisa ser ampla, de maneira a garantir às suas deliberações o grau máximo de legitimidade e representatividade. Os usuários devem ser representados paritariamente ao lado

\footnotetext{
${ }^{50}$ BARROS, Elizabeth. O controle social e o processo de descentralização dos serviços de saúde. In: BRASIL. Ministério da Saúde. Coordenação de Informação, Educação e Comunicação. Incentivos à participação popular e controle social do SUS: textos técnicos para conselheiros de saúde. Brasília, 1998, p.19
} 
dos demais segmentos (administração pública, prestadores de serviços e profissionais da saúde). O número de vagas para as entidades e organizações representativas dos usuários deve corresponder obrigatoriamente à metade do total de participantes das Conferências e dos Conselhos ${ }^{51}$.

As Conferências de Saúde são arenas com representação dos segmentos sociais que se reúnem a cada quatro anos para a avaliação da saúde e a propositura de diretrizes da política de saúde, conforme o artigo $1^{\circ}$, parágrafo $1^{\circ}$ da Lei $\mathrm{n}^{\circ}$ 8.142/90. Sua realização é responsabilidade do governo, convocadas pelo Poder Executivo ou de pelo Conselho de Saúde, excepcionalmente. Nas Conferências há a oportunidade de discussão de problemas e suas possíveis soluções. As resoluções das Conferências de Saúde servem de parâmetro para as decisões dos gestores e dos Conselhos de Saúde.

Por sua vez, os Conselhos de Saúde (Lei nํㅗ 8.142/90, artigo 1ํㅜㄹ parágrafo $2^{\circ}$ ) são órgãos colegiados, de natureza permanente e deliberativa, incumbidos de formular estratégias, controlar e fiscalizar a execução da política de saúde abarcando os aspectos econômicos e financeiros. As decisões dos Conselhos exigem homologação do Chefe do Poder Executivo. Para o correto exercício da atividade fiscalizatória os conselheiros de saúde devem ter à sua disposição recursos humanos, materiais e informações acerca dos problemas que afetam a saúde da população e o montante e a alocação de receitas.

c) integralidade no atendimento, priorizando as atividades preventivas, sem desprezo dos serviços assistenciais (artigo 198, inciso II): o princípio prescreve a articulação e continuidade do plano das ações e serviços preventivos e assistenciais ou curativos, em todos os níveis do sistema de saúde (artigo 7º, inciso II, da Lei

${ }^{51}$ BARROS, Elizabeth. Op. Cit., p. 20. 
Orgânica da Saúde - LOS). A integralidade envolve o atendimento das pessoas em sua totalidade, considerando as diversas condições de vida e de trabalho, que podem acarretar doenças e morte. O ser humano deve ser compreendido em sua dimensão social, cidadã, biológica, psicológica e vulnerável às adversidades da vida. Assim, o atendimento é de atenção à saúde, diferente do foco para a doença. Esse olhar para a saúde demanda que o atendimento seja meio de erradicação de causas e diminuição de riscos, ao lado do tratamento dos males. O Sistema Único de Saúde (SUS) deve garantir o acesso a ações preventivas, que eliminem ou controlem as causas das doenças e agravos e englobam outros direitos sociais como moradia digna, meio ambiente saudável, educação de qualidade; ações protetivas, que previnem riscos e exposições às enfermidades, condutas de manutenção das condições de saúde pública ( saneamento básico, imunizações e vigilância sanitária) e recuperação, para evitar a morte de pessoas doentes, a incidência de sequelas, agindo sobre os danos (atendimento médico, tratamento e reabilitação dos doentes). Em resumo, o ser humano é um ser integral, biopsicossocial e deverá ser tratado de forma global para que sua saúde seja promovida, protegida e recuperada;

d) regionalização e hierarquização (artigo 198, caput): estes princípios favorecem ações de vigilância epidemiológica, sanitária, controle de vetores, educação em saúde e a atenção ambulatorial e hospitalar em todos os graus de complexidade. $\mathrm{O}$ acesso das pessoas à rede de atenção à saúde deve ter seu início nos estabelecimentos e serviços de nível primário, qualificados para o atendimento e resolução das principais queixas. O que não puder ser solucionado nesse nível deverá ser referenciado para os serviços de saúde de maior complexidade tecnológica. A regionalização, por conseguinte, não é a simples distribuição espacial 
de estabelecimentos e serviços, é, em verdade, o ato de organizar as estruturas citadas com os recursos humanos e materiais indispensáveis.

Os serviços e as ações de saúde são organizados segundo níveis de complexidade em grau crescente, numa área territorial definida e população delimitada. Ao lado desses princípios, o artigo $7^{\circ}$ apresenta outros, quais sejam:

a) preservação da autonomia pessoal na proteção e defesa de suas integridades física e moral, o que explicita o respeito à capacidade individual na tomada de decisões, abarcando a eleição do procedimento médico a ser implementado, desde que eficaz para a preservação da saúde ou da comunidade (artigo $7^{\circ}$, inciso III);

b) direito à informação das pessoas assistidas sobre o seu estado de saúde (artigo $7^{\circ}$, inciso $\left.\mathrm{V}\right)$;

c) divulgação de informações aos usuários acerca do potencial dos serviços de saúde e sua utilização (artigo 7ํㅜ, inciso VI);

d) uso da epidemiologia para a fixação de prioridades, a alocação de recursos e a orientação dos programas de atenção à saúde (art. 7º, inciso VII);

e) integração no plano executivo das ações de saúde, meio ambiente e saneamento básico (artigo $7^{\circ}$, inciso X);

f) reunião dos recursos financeiros, tecnológicos, materiais e humanos da União, dos Estados, do Distrito Federal e dos Municípios na prestação de serviços de assistência à saúde da população (artigo 7º, inciso XI);

g) capacidade de resolução dos estabelecimentos e serviços em todos os níveis de assistência à saúde (artigo 7ํㅜ, inciso XII) e

h) organização dos serviços públicos para impedir meios dúplices para finalidades iguais (artigo $\left.7^{\circ}, \mathrm{XIII}\right)$. 
Podemos afirmar que esses princípios regulam tanto a prestação de serviços de saúde quanto a singular organização do Sistema Único de Saúde (SUS), o qual adota a mesma diretriz e os mesmos princípios em todo o território nacional, sob a responsabilidade das três instâncias autônomas do Estado Brasileiro: governo federal, estadual e municipal. Logo, o SUS não é um serviço ou uma instituição, mas um sistema, que representa um conjunto de unidades, serviços e ações que interagem para um escopo comum.

Por sua vez, o artigo 200 da Constituição Federal elenca as atribuições do Sistema Único de Saúde de modo não exauriente:

a) controle e fiscalização de produtos, procedimentos e substâncias para a saúde ( inciso I);

b) participação na produção de medicamentos, equipamentos, imunobiológicos, hemoderivados e demais insumos ( ainda no inciso I);

c) execução da vigilância sanitária e epidemiológica ( inciso II);

d) atenção à saúde dos trabalhadores ( também no inciso II);

e) formação de recursos humanos na área da saúde ( inciso III);

f) participação na formulação da política e da execução do saneamento básico ( inciso IV);

g) desenvolvimento científico e tecnológico em saúde ( inciso $\mathrm{V})$; 
h) fiscalização e inspeção de produtos alimentícios, bebidas e águas para o consumo humano conforme o seu teor nutricional ( inciso VI);

i) participação no controle e fiscalização da produção, transporte, guarda e utilização de substâncias e produtos radioativos, psicoativos e tóxicos ( inciso VII) e

j) colaboração na proteção do meio ambiente natural e do trabalho ( inciso VIII).

O legislador constituinte apresenta no artigo 208, inciso VII, a assistência à saúde entre os programas suplementares à política pública de educação no ensino fundamental.

Mais adiante no artigo 220, parágrafo $3^{\circ}$, inciso II, temos a possibilidade da edição de uma lei federal restritiva da propaganda de produtos, práticas e serviços nocivos à saúde e ao meio ambiente.

No artigo 227 há a determinação do dever da família, da sociedade e do Estado de assegurar à criança e ao adolescente, pessoas em peculiar desenvolvimento o direito à saúde. O parágrafo 1ํ desse artigo traz a participação de organizações não governamentais na promoção de programas de assistência integral à saúde da criança e do adolescente e determina ainda a aplicação de percentual dos recursos públicos destinados à saúde na assistência materno-infantil (inciso I).

Assim, há um grande número de dispositivos constitucionais e infraconstitucionais que tratam, diretamente, da saúde, o que mostra a atenção do Poder Constituinte, inclusive o derivado, em conceder efetividade plena a esse direito humano: as Leis que representam a Lei Orgânica da Saúde (Leis 8.080 e 
8.142, ambas de 1990); os diversos Códigos Sanitários Estaduais e Municipais; as Leis de criação das Agências Nacionais de Vigilância Sanitária (Lei n. 9.782/1999) e de Saúde Suplementar (Lei n. 9.656/1998); a Lei que criou a Hemobrás e também a Lei de Bioética (Lei n. 11.105/2005), entre outras diversas que tratam privativamente de assuntos relacionados com a promoção, proteção e recuperação da saúde no Brasil. Isso sem falar dos inúmeros regulamentos administrativos (Decretos, Portarias, Resoluções etc.). O Direito Sanitário ${ }^{52}$ merece um estudo especial dada a sua complexidade e o seu sentido na sociedade brasileira: apresentar subsídios para a correta organização das ações e serviços de saúde, proteger os valores juridicamente relevantes e contribuir para o desenvolvimento integral dessa mesma sociedade.

Especificamente para a nossa pesquisa, consignamos que as mulheres são a maioria da população brasileira e as principais usuárias do Sistema Único de Saúde (SUS). Utilizam os serviços públicos de saúde para o próprio atendimento, de suas famílias e comunidades. Já observamos que o direito fundamental à saúde envolve diferentes aspectos da vida: alimentação, meio ambiente, educação, moradia, emprego e renda. Para a mulher negra a vulnerabilidade é acentuada pela discriminação de raça/etnia e de gênero. Essa vulnerabilidade diante de certas enfermidades e causas de morte está relacionada às violações de direitos humanos bem mais do que a condições biológicas. Ou seja, para a concretização do direito fundamental à saúde da mulher negra devemos considerar a negação do acesso ou o acesso precarizado às ações de prevenção, promoção e recuperação em saúde.

Segundo dados apresentados pelo IBGE-Instituto Brasileiro de Geografia e Estatística, em 2010, a população brasileira chegava a 191 milhões de habitantes.

\footnotetext{
52 AITH, Fernando Mussa Abujamra Consolidação do Direito Sanitário no Brasil In: O Direito achado na rua : Introdução crítica ao direito à saúde. / Alexandre Bernardino Costa ... [et al.](organizadores) - Brasília: CEAD/ UnB, 2009.p. 67-75.
} 
Pela primeira vez em nosso país, a população negra é majoritária, contabilizando 97 milhões de pessoas, sendo 49 milhões o número de mulheres negras no Brasil ${ }^{53}$.

Vale destacar que a efetividade dos direitos fundamentais e, por conseguinte, do direito fundamental à saúde da mulher negra depende de políticas públicas de reconhecimento de realidades e promotoras da real igualdade ${ }^{54}$.

\subsection{A reforma sanitária e o direito fundamental à saúde}

A saúde deve ser compreendida como um estado de equilíbrio físico, intelectual e emocional do ser humano. O processo saúde-doença implica na análise da relação humana com os ambientes naturais e culturais, suas condições materiais de vida e do modo de produção e distribuição de riqueza em determinados espaço/tempo.

Até à Constituição de 1988 a saúde não era um direito universal consagrado. A Constituição de 1934 em seu artigo 10 atribuía competência concorrente da União e dos Estados no cuidado da saúde. Os documentos constitucionais seguintes conferiram exclusividade da União no planejamento e organização de sistemas de saúde $^{55}$ e apenas a assistência médica era oferecida a quem fosse trabalhador assalariado, com carteira assinada e contribuinte da Previdência Social.

O sistema de saúde brasileiro transformou-se de centralizado e contributivo para o panorama de universalização e municipalização, afirma Falleti ${ }^{56}$. Antes da

\footnotetext{
${ }^{53}$ Saúde da mulher negra: guia para a defesa dos direitos das mulheres negras / Articulação de Organizações de Mulheres Negras Brasileiras. - Porto Alegre, 2012.p.7.

${ }_{54}^{5}$ PRUDENTE, Eunice Aparecida de Jesus. Educação em Direitos- um caminho para a Igualdade Racial.p.24.

${ }^{55}$ DALLARI, Sueli Gandolfi. A construção do direito à saúde no Brasil. Revista de Direito Sanitário, São Paulo, v. 9, n.3, p.10.

${ }^{56}$ FALLETI, T." INFILTRANDO O ESTADO: A EVOLUÇÃO DA REFORMA DA SAÚDE NO BRASIL, 1964 - 1988" Tradução: Alan César Belo ANGELUCI Estud. sociol., Araraquara, v.15, n.29, p.345368,2010
} 
Constituição de 1988, a administração do sistema de saúde era centralizada no Governo Federal. Estados e municípios desempenhavam papel mínimo na gestão e na distribuição de cuidados de saúde; havia o financiamento público para os contratos de prestação de serviços com o setor privado e grande parte da população não tinha acesso aos cuidados de saúde. Os cidadãos brasileiros não tinham acesso aos cuidados de saúde pois: a) não tinham direito à previdência social; b) não tinham seguro-saúde e/ou c) não existiam serviços de saúde em seu bairro ou cidade. Os serviços de saúde eram organizados em três subsistemas: o setor privado, o público e de previdência social. No setor público: os serviços de saúde eram uma responsabilidade compartilhada dos governos federal, estadual e municipal.

As atribuições do Governo Federal eram a vacinação e o controle de surto de epidemias. Os Governos estaduais e municipais cooperavam com o plano federal.

No governo de Getúlio Vargas, o sistema de saúde brasileiro estruturou o sistema de previdência social como um dos pilares da organização do Estado corporativista (demais elementos: Justiça do Trabalho e estrutura sindical).

No regime militar houve a instalação de um único organismo, o Instituto Nacional de Previdência Social (INPS) e a substituição de presidentes e conselhos comprometidos com as causas sociais e políticas por tecnocratas. O INAMPS (Instituto Nacional de Assistência Médica da Previdência Social) foi criado para coordenar os serviços de saúde do sistema de previdência social. Institucionalizou um sistema de saúde de alto custo, especializado, curativo e hospitalar, concentrado nas regiões lucrativas do país.

O FUNRURAL (Fundo de Assistência ao Trabalhador Rural do Governo Militar em sua fase mais repressiva - Presidente Médici, de 1969 a 1974) 
intensificou a concessão de cobertura de previdência social e saúde à população rural, extensão do alcance do Estado ao Norte e Nordeste, penetração e cooptação das organizações de trabalhadores rurais e privilégio para o setor privado de saúde.

O Movimento Sanitário dos profissionais de saúde surgiu no período desenvolvimentista do início dos anos 1960 (Presidente Jango). Teve a sua origem no meio acadêmico e associou a luta política a uma proposta técnica composta por vários elementos: produção e divulgação de conhecimentos, ocupação de espaços institucionais e trabalho com parlamentares, com enfoque no suprapartidarismo.

Inicialmente adotou um discurso de prevenção, voltado para a prática e educação médica, o movimento passou para as reflexões sobre os sistemas e políticas de saúde.

Os três pilares do Movimento Sanitário:

- ênfase nos cuidados preventivos, visão de saúde: direito humano universal aliado à condição socioeconômica dos cidadãos, vinculado ao acesso à moradia, à educação e ao emprego (CEBES, 1980; Conferência Nacional de Saúde, 1986);

- prática de grande variedade de modelos de medicina preventiva e medicina social e orientação ideológica à reforma da saúde;

- produção e disseminação de propostas de uma reforma progressista da saúde; ocupação de posições de poder, leia-se "infiltração do Estado" como uma influência do Congresso Nacional e Ministério da Saúde mais "permeáveis" a novas ideias e atores: estratégias do movimento sanitarista na análise de Falleti. A organização político-administrativa do país na forma federativa colaborou para a infiltração no aparelho do Estado de líderes reformistas. Os chefes do Executivo eleitos abriram as portas das secretarias municipais de saúde para membros do movimento sanitário reformista. 
O Programa de Interiorização das Ações de Saúde e Saneamento (PIASS 1976): implantação de rede de pequenas unidades de saúde em localidades de baixa densidade populacional. Integração dos serviços de saúde local, sob a coordenação das secretariais estaduais de saúde. Desempenhou importante papel na universalização e municipalização de saúde. Sua vigência teve como princípios: a cobertura universal, a igualdade de atenção, a descentralização, a regionalização, a articulação entre os níveis de governo e a participação comunitária. Ocorreu importante transferência de recursos e colaboradores da burocracia da previdência social para as secretarias estaduais e municipais de saúde

Em 1979 no I Simpósio Nacional de Política de Saúde, realizado pela Comissão de Saúde da Câmara de Deputados, o movimento com a representação do CEBES - Centro Brasileiro de Estudos de Saúde debateu publicamente e de forma inédita a sua plataforma de nova orientação do sistema de saúde.

As Ações Integradas de Saúde (AIS) foram mais efetivas do que o programa anterior. Permitiu a integração dos serviços de saúde do Ministério da Saúde e do Ministério da Educação e Cultura. A Coordenação de diferentes níveis de governo foi uma experiência de administração descentralizada sob a liderança de Eleutério Rodriguez Neto, primeira indicação de médico sanitarista para posição estratégica na gestão dos serviços de saúde. A adoção da proposta da Autorização de Internação Hospitalar (AIH) reorientou a política de assistência médica, alterou a forma de remuneração do setor privado e introduziu a celebração de convênios com Estados e Municípios para a utilização dos equipamentos públicos ociosos.

A 8a Conferência Nacional de Saúde em Brasília (março de 1986) foi convocada para debater a nova proposta de estrutura e política de saúde. A Conferência apresentou a proposta de criação do Sistema Único de Saúde baseada 
em três grandes questões: a) saúde como direito; b) reformulação do sistema nacional de saúde e c) financiamento do setor saúde. O relatório formulado por vários segmentos sociais foi encaminhado à Assembleia Nacional Constituinte.

A reforma sanitária ${ }^{57}$ é a proposta para a democratização da saúde no país. Compreende a saúde como resultado das condições de vida dos seres humanos. A saúde integral não se resume à assistência médica. Depende do acesso das pessoas à educação de qualidade, à moradia digna, ao saneamento básico, ao mercado de trabalho, à cultura e ao lazer.

Saúde direito de todas e todos e dever do Estado são os princípios da Reforma Sanitária. Para a realização desses princípios as políticas públicas devem ser estruturadas e organizadas de maneira que a saúde das pessoas seja impactada positivamente na promoção do bem-estar, na prevenção e atendimento adequado de doenças e acidentes ${ }^{58}$.

Etapa necessária após a apresentação do histórico da política de saúde pública no Brasil é o exame das reflexões dos pesquisadores de política e gestão em saúde. Madel Therezinha Luz sustenta que o sistema de atenção à saúde reflete a concentração de poder social característica da sociedade brasileira. É válida a transcrição:

\begin{abstract}
É importante assinalar aqui que a intensa movimentação da sociedade civil teve um papel muito importante para a aceitação, na política oficial, das propostas da VIII Conferência Nacional de Saúde, em grande parte consubstanciadas no SUS (Luz, 1994). O Congresso Nacional tomou em consideração e aprovou em 1988 essas propostas, não apenas, porque os antigos atores de mudanças nas políticas de saúde - profissionais de saúde, burocracia do Ministério da Saúde e da Previdência - estavam presentes e atuando ativamente neste sentido, inclusive como deputados. Mas porque havia uma efetiva participação popular na
\end{abstract}

\footnotetext{
${ }^{57}$ RODRIGUEZ NETO, Eleutério. A Reforma Sanitária e o Sistema Único de Saúde: suas origens, suas propostas, sua implantação, suas dificuldades e suas perspectivas. In: Brasil. Ministério da Saúde. Coordenação de Informação, Educação e Comunicação. Incentivos à participação popular e controle social no SUS: textos técnicos para conselheiros de saúde. Brasília, 1998, p. 7-17.

${ }^{58}$ RODRIGUEZ NETO, Eleutério. Idem.
} 
busca dessas mudanças. Pela primeira vez uma política pública se oficializou no país, que buscava, ao menos no seu discurso, a descentralização e a desconcentração em proveito de instâncias intermediárias de poder institucional. O controle social do cidadão ficou garantido através de participação em Conselhos (estaduais, municipais) destinados a este fim. A saúde tornou-se a vanguarda das políticas públicas nessa questão. Entretanto, grande parte desse instrumento de descentralização política que é o SUS ficou sem regulamentação até o fim dos anos oitenta ${ }^{59}$.

A timidez no planejamento em saúde no Brasil aliada à já mencionada concentração de poder são objetos de estudo de Cristiani Vieira Machado, Tatiana Wargas de Faria Baptista e Luciana Dias de Lima ${ }^{60}$.

Em que pesem os avanços observados, o planejamento em saúde no período expressa fragilidades. Algumas delas se relacionam à complexidade do campo e da condução nacional de uma política de implementação descentralizada: as limitações na realização de uma adequada análise situacional, a escassez de mecanismos de coordenação, diante de uma grande variedade de ações e metas, as dificuldades na definição de atribuições positivas para o gestor federal $e$ os conflitos federativos relacionados à centralização/descentralização. Porém, as maiores fragilidades remetem a fatores de ordem geral, que sinalizam um lugar modesto da política de saúde no modelo de desenvolvimento. Um deles é a não regulamentação do financiamento da saúde, que tem comprometido as propostas delineadas nos instrumentos setoriais de planejamento. Outro é o caráter delimitado das prioridades governamentais para o setor e o pouco enfrentamento de problemas estruturais do sistema de saúde, como as distorções nas relações público-privadas e as imensas desigualdades em saúde. Por fim, ressalte-se a fragilidade da lógica territorial no planejamento em saúde, que reflete um fenômeno mais geral de limitada apropriação da dimensão territorial no planejamento nacional. É premente a retomada da abordagem territorial com vistas à formulação de políticas diferenciadas segundo necessidades regionais e a realização de investimentos para a redução das desigualdades em saúde. Em um país imenso, heterogêneo e desigual, essas são questões críticas a serem enfrentadas para que o planejamento seja uma prática transformadora da realidade social.

\footnotetext{
59 LUZ, Madel Therezinha. Duas questões permanentes em um século de políticas de saúde no Brasil republicano. Ciência \& Saúde Coletiva, 5(2):293-312, 2000.

${ }_{60}$ MACHADO, Cristiani Vieira, BAPTISTA,Tatiana Wargas de Faria, LIMA, Luciana Dias de. $O$ planejamento nacional da política de saúde no Brasil: estratégias e instrumentos nos anos 2000. Ciência \& Saúde Coletiva, 15(5):2367-2382, 2010.
} 


\subsection{Direito Sanitário no Brasil}

O Direito Sanitário ${ }^{61}$ é o ramo do direito que estuda o conhecimento, interpretação e aplicação das normas jurídicas protetivas do direito à saúde. Suas maiores finalidades são a redução dos riscos de doenças e outros gravames à saúde e a garantia do acesso universal e igualitário às ações e serviços públicos de saúde. Por ações e serviços de interesse à saúde compreende-se não só as ações e serviços de saúde especificamente considerados (vigilância em saúde, hospitais, atendimentos médicos etc.) como também ações e serviços que possam representar riscos à saúde (produção, distribuição e comercialização de bens, produtos e serviços, pesquisas de bioética etc.).

\subsubsection{O direito à saúde no plano internacional}

No plano internacional, muitos documentos direta ou indiretamente tratam do direito fundamental à saúde ${ }^{62}$.

O artigo 1ํㅜㄹ item 3, da Carta das Nações Unidas veicula os objetivos da ONU:

[...] conseguir uma cooperação internacional para resolver os problemas internacionais de caráter econômico, social, cultural ou humanitário, e para promover e estimular o respeito aos direitos humanos e às liberdades fundamentais para todos, sem distinção de raça, sexo, língua ou religião.

${ }^{61}$ É o que se extrai do trabalho de Sueli Dallari, que esclarece que o direito da saúde pública é parte do direito administrativo ou uma aplicação especializada desse ramo jurídico, contudo, após a Constituição de 1988 em que a saúde integra o conceito de seguridade social ( artigo 194), a referência ao direito administrativo é insuficiente. DALLARI, Sueli Gandolfi. Uma nova disciplina: o direito sanitário. Revista de Saúde Pública, São Paulo, v.22, n.4, ago.1988.

${ }^{62}$ AITH, Fernando Mussa Abujamra. Consolidação do Direito Sanitário no Brasil. In: O Direito achado na rua : Introdução crítica ao direito à saúde. / Alexandre Bernardino Costa ... [et al.](organizadores) - Brasília: CEAD/UnB, 2009. 
A Declaração Universal dos Direitos Humanos de 1948 e a disposição do preâmbulo:

[...] o desprezo e o desrespeito pelos direitos da pessoa resultaram em atos bárbaros que ultrajaram a consciência da Humanidade e que o advento de um mundo em que as pessoas gozem de liberdade de palavra, de crença e liberdade de viverem a salvo do temor e da necessidade foi proclamado como a mais alta aspiração do homem comum.

E mais adiante o art. 25, item 1versa sobre os cuidados indispensáveis para a vida humana com dignidade.

O Pacto dos Direitos Sociais, Culturais e Econômicos, de 1966, representa um marco na proteção da saúde e estabelece que "os Estados-partes reconhecem o direito de toda pessoa de desfrutar o mais elevado nível de saúde física e mental", em seguida (art. 12-2) dispõe que sobre as providências que os Estados devem adotar para a promoção e proteção do direito à saúde.

O sistema global de proteção do direito à saúde ganha destaque com a Organização Mundial de Saúde (OMS), organismo que entrou em funcionamento no dia 7 de abril 1948. O artigo $1^{\circ}$ de sua Constituição traz a previsão de que o papel da OMS é o de possibilitar para todos os povos o melhor nível de saúde possível. No preâmbulo da Constituição, os Estados-partes declaram que, em conformidade com a Carta das Nações Unidas, os seguintes princípios são básicos para a felicidade e relação harmoniosa e segurança de todos os povos:

a) saúde é o estado de completo bem-estar físico, mental e social, e não somente a ausência de doenças ou enfermidades;

b) o gozo do maior padrão de saúde desejado é um direito fundamental de todos os seres humanos, sem distinção de raça, religião, opção política e condição econômica e social; 
c) a saúde de todos os povos é fundamental para a consecução da paz e segurança e depende da cooperação dos indivíduos e dos Estados;

d) o sucesso de um país na promoção e proteção da saúde é bom para todos os países;

e) o desenvolvimento iníquo em diferentes países para a promoção da saúde e controle de doenças, especialmente as contagiosas, é um perigo comum;

f) o desenvolvimento da saúde da criança é de importância básica;

g) a extensão para todos os povos dos benefícios advindos dos conhecimentos médicos, psicológicos e afins é essencial para atingir a saúde;

h) opinião informada e cooperação ativa do público são de importância crucial na melhoria da saúde da população;

i) governos têm a responsabilidade pela saúde de seus povos, que pode ser garantida apenas através da adoção de medidas sociais e de saúde adequadas.

Os princípios são os grandes regentes do Direito Internacional na promoção e proteção da saúde. É o Direito Internacional Sanitário que disciplina a regulação das ações e serviços de interesse à saúde em nível global, seus grandes propósitos são a redução dos riscos de doenças e outros gravames à saúde e a garantia do acesso universal e igualitário às ações e serviços públicos. O Direito é um dos principais instrumentos colocados à disposição das cidadãs e cidadãos para o alcance dos 
valores Justiça e Saúde, independentemente de diferenças culturais, sociais, econômicas, morais etc.

Ao lado do sistema global, temos os sistemas regionais de proteção dos direitos humanos. No continente americano, destaca-se a Organização dos Estados Americanos (OEA), constituída a partir da Carta da Organização dos Estados Americanos, assinada em 30 de abril de 1948, durante a IX Conferência Interamericana, realizada na cidade de Bogotá na Colômbia.

Um dos principais documentos da OEA para a proteção da saúde é a Convenção Americana de Direitos Humanos, aprovada em 22 de novembro de 1969, na Conferência de São José da Costa Rica.

No âmbito regional americano, destaca-se também a Organização PanAmericana de Saúde (OPAS). As atividades da OPAS são "dirigidas à busca da equidade nas ações que beneficiem grupos mais vulneráveis."

\section{6. O papel do Poder Executivo nacional na construção do direito à}

\section{saúde}

Com a previsão constitucional do direito à saúde e da consequente criação de um sistema de saúde, as ações e serviços passam a ser responsabilidade precípua do Poder Executivo. Cabe ao Executivo em parceria com a sociedade civil, elaborar, implementar e executar as políticas públicas sanitárias ${ }^{63}$. A Reforma Sanitária está institucionalizada no Poder Executivo e atualmente o Ministério da Saúde (MS) é a principal autoridade em nível federal que cumpre o dever do Estado brasileiro de garantir o direito à saúde a todos. Ao lado da primazia do Ministério da

${ }^{63}$ DELDUQUE, Maria Célia; OLIVEIRA, Mariana S. de Carvalho. Tijolo por tijolo: a construção permanente do direito à saúde. In: O Direito achado na rua: Introdução crítica ao direito à saúde. I Alexandre Bernardino Costa. [et al.](organizadores) - Brasília: CEAD/UnB, 2009. 
Saúde temos os princípios da descentralização que confere autonomia maior aos estados e aos municípios nas ações e serviços de saúde locais e da gestão participativa.

\subsection{O papel do Poder Legislativo na construção do direito à saúde}

As normas oriundas do Parlamento é que disciplinadora e definidora das atividades estatais de promoção da saúde. Nossos representantes no Legislativo também explicitam a forma e os critérios subsidiários da formulação e implementação das políticas públicas de saúde, as normas específicas de bens e serviços de saúde e a regulamentação de profissões do setor. Esse sistema normativo exarado pelo Estado legislador que traz a disciplina da saúde, a organização e o funcionamento das instituições destinadas à sua promoção e defesa do direito fundamental à saúde.

\subsection{O papel do Poder Judiciário na construção do direito à saúde}

Nossa Constituição Federal apresenta a universalidade da cobertura e do atendimento das ações e serviços de saúde conforme citação anterior. Ao mesmo tempo prevê o direito de acesso à justiça e a garantia da inafastabilidade do Poder Judiciário nas hipóteses de lesão e ameaça a direitos (artigo 5ํㅡ, inciso XXXV). As cidadãs e os cidadãos brasileiros estão autorizados pela nossa ordem jurídica de

postular o direito fundamental à saúde em face do Poder Judiciário, requerendo a tutela do Poder Público para a efetividade desse direito, em contraponto às ações e omissões violadoras oriundas do próprio Estado. 
A atuação do Judiciário é carregada de subsidiariedade e excepcionalidade, melhor dizendo, diante das omissões e atuações insuficientes dos demais poderes estatais e apenas sob provocação individual ou coletiva, ocorre a intervenção judicial. Nosso Estado Social pressupõe, diferentemente do Estado Liberal, que o Poder Judiciário é destinatário dos deveres constitucionais de zelo e garantia do valor dignidade humana. Para garantir a dignidade humana devemos assegurar as condições materiais mínimas para o próprio exercício do "direito à personalidade integral-cidadania plena" ${ }^{\prime \prime}$.

\subsection{0 direito à equidade racial na atenção à saúde}

Para as populações negras africanas, a diáspora resultante do processo de escravização a que foram submetidas ao longo dos séculos XVII a XIX consistiu também numa trajetória de genocídio. Os afrodescendentes chegaram ao século XXI como um segmento expressivo da população brasileira $-45 \%$, segundo 0 Censo 2000 do Instituto Brasileiro de Geografia e Estatísticas (IBGE) - porém detentor dos piores indicadores socioeconômicos.

Tal quadro resulta de uma ideologia racista que define os campos políticos, sociais e econômicos da população negra brasileira. Ainda na atualidade, a questão racial no Brasil é considerada por muitos como simples consequência das desigualdades sociais e econômicas, o que deságua na omissão do olhar do recorte de raça/etnia nas políticas públicas e materialização da dignidade humana.

Após a abolição oficial da escravatura, foram muitos os anos de luta envolvendo denúncias sobre a fragilidade do modelo brasileiro de democracia racial, até a fundação da Frente Negra Brasileira, em 1931. A partir de então, as questões e demandas de classe e raça

\footnotetext{
${ }^{64}$ Como bem explica e sintetiza Eunice Aparecida de Jesus Prudente em sua Tese de Doutoramento : "Direito à personalidade integral-cidadania plena", Faculdade de Direito, Universidade de São Paulo.
} 
ganharam projeção na arena política brasileira, fortalecidas, posteriormente, pelo Movimento Social Negro, que atua organizadamente desde a década de $1970 .^{65}$

O movimento negro desde a década de 1970 trabalhou na visibilidade do racismo institucional e dos seus efeitos perversos sobre os diferentes aspectos da vida da população negra, entre eles, o tratamento desigual no direito fundamental à saúde. A relevância do princípio da equidade ganha destaque, ou seja, a população negra brasileira precisa de condições especiais de tratamento nas ações e serviços de saúde. ${ }^{66}$ Nesse sentido, a Declaração Política sobre Determinantes Sociais da Saúde do Rio de Janeiro:

Desigualdades na saúde surgem das condições sociais em que as pessoas nascem, crescem, vivem, trabalham e envelhecem, as quais recebem a denominação de determinantes sociais da saúde. Estas incluem experiências dos primeiros anos, educação, status econômico, emprego e trabalho digno, habitação e meio ambiente, e sistemas eficazes de prevenção e tratamento de problemas de saúde. Estamos convencidos de que a ação sobre esses determinantes, tanto para grupos vulneráveis e toda a população, é essencial para criar inclusiva, equitativa, sociedades economicamente produtiva e saudável.

Surge a urgência das ações afirmativas, inclusive o incentivo ao processo de empoderamento da população de mulheres e homens afrodescendentes.

Nossa atenção para a equidade no direito fundamental à saúde da população negra guarda fundamento na Constituição Federal de 1988, que apresentou novas diretrizes para as relações étnico-raciais no país. O legislador constituinte de 1988 estabeleceu entre os objetivos fundamentais da República a "promoção do bem de todos sem preconceitos", inclusive de raça (artigo $3^{\circ}$, incisos I, III e IV). Escolheu no rol dos princípios no plano internacional o repúdio ao racismo (artigo $4^{\circ}$, inciso

\footnotetext{
65 Política Nacional de Saúde Integral da População Negra. Ministério da Saúde. Secretaria de Gestão Estratégica e Participativa. Brasília, DF . Fevereiro de 2007 .p.17.

${ }^{66}$ Declaração Política sobre Determinantes Sociais da Saúde do Rio de Janeiro In: Saúde da população negra / Luís Eduardo Batista, Jurema Werneck e Fernanda Lopes, (orgs.). --2. ed. rev. e ampl., 1. reimpr. -- Brasília, DF ABPN - Associação Brasileira de Pesquisadores Negros, 2012. -- (Coleção negras e negros :pesquisas e debates / coordenação Tânia MaraPedroso Müller)
} 
VIII),aliás tal prática recebe o tratamento jurídico de "crime inafiançável e

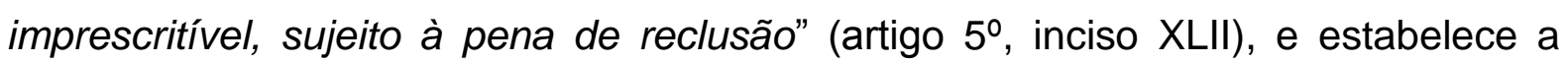
proteção das culturas afrobrasileiras (art. 215, parágrafo $1^{\circ}$ ), além de prever 0 reconhecimento no artigo 69 do Ato das Disposições Constitucionais Transitórias (ADCT) da propriedade rural das comunidades remanescentes de quilombos .

O debate da $12^{\text {a }}$ Conferência Nacional de Saúde (CNS) de 2003 determinou entre as diretrizes específicas, a garantia e ampliação do acesso da população negra (parágrafo 62), e o estabelecimento de políticas públicas relativas à anemia falciforme e às hemoglobinopatias, em que se destacam o diagnóstico precoce, o aconselhamento genético e "o registro adequado das ocorrências de óbitos" na segunda enfermidade ( parágrafo 63).

O Plano Nacional de Saúde contemplou a saúde integral da população negra (2004 / 2010), foi instituído pela Portaria MS n. 2.607, de 10 de dezembro de 2004, e apresentou diretrizes destinadas à "promoção da equidade na atenção à saúde da população negra". Essas ações de caráter afirmativo abrangem a capacitação de profissionais do SUS, o aperfeiçoamento do acesso das comunidades quilombolas às ações e serviços de saúde, a participação no planejamento e monitoramento das políticas em saúde e a inserção do quesito raça/cor nos instrumentos de coleta de informação e na análise dos dados em saúde. Na esteira das recomendações da $12^{\text {a }}$ CNS, foi criado no âmbito do Ministério da Saúde o Comitê Técnico de Saúde da População Negra, pela Portaria n. 1.678/GM, de 13 de agosto de 2004. O comitê é composto por pesquisadores de todas as áreas do Ministério e tem como atribuição estudar e formular propostas de programas de equidade na atenção à saúde da população negra. Outra conquista relevante foi a questão da produção de conhecimento científico para o embasamento de decisões em políticas públicas. $O$ 
Programa Nacional de Doenças Sexualmente Transmissíveis ( DST) e AIDS incluiu a saúde da população negra em suas linhas de pesquisa.

É importante consignar que o papel da Secretaria Especial de Políticas de Promoção da Igualdade Racial (Seppir) é o de articulação e formulação de políticas de promoção do direito à igualdade racial, não é de gestão da política pública de saúde, que é dever do Ministério da Saúde. Esse quadro de separação entre o direito à saúde e o direito à igualdade racial reflete a desvinculação entre a política universal do SUS e a atenção às peculiaridades da temática dos direitos humanos para a efetivação da dignidade da mulher negra, sub-representada política e institucionalmente ${ }^{67}$.

Acertado é o entendimento de Gislene Aparecida dos Santos, baseado nas contribuições de Axel Honneth, Charles Taylor e Will Kymlicka ao pugnar pelo reconhecimento das identidades para a formulação de políticas multiculturais para a efetivação dos direitos humanos ${ }^{68}$.

A negação do reconhecimento das diferenças torna impossível a construção de um sentido de comunidade cívico humanista. Por isso, a ausência do reconhecimento das diferenças também aparece como um "problema" ou obstáculo para a construção de uma sociedade na qual a fragmentação não seja ampliada de modo que cada grupo corresponda a uma unidade fechada sobre si mesma, impossibilitando qualquer forma de convívio.

Para Gislene Santos, Honneth ${ }^{69}$ tem sua análise calcada no sentimento de injustiça aliado à negação de direitos. Podemos facilmente aplicar esse sentimento

\footnotetext{
${ }^{67}$ Articulação de Organizações de Mulheres Negras Brasileiras Saúde da mulher negra: guia para a defesa dos direitos das mulheres negras / Articulação de Organizações de Mulheres Negras Brasileiras. - Porto Alegre, 2012.p.51

${ }^{68}$ SANTOS, Gislene Aparecida dos. As políticas multiculturais e o reconhecimento de identidades como novas formas de contrato social e efetivação da justiça. CCJUR em Revista , 2010, ISSN 1679-4206 [no prelo]

${ }^{69}$ HONNETH, Axel. Reconhecimento ou redistribuição? A mudança de perspectivas na ordem moral da sociedade. In: SOUZA, Jessé; MATTOS, Patrícia (orgs.). Teoria Crítica no século XXI. São Paulo: Annablume, 2007.
} 
de injustiça nas práticas discriminatórias que atingem as mulheres negras nas ações e serviços de saúde. E assim:

Não havendo reconhecimento, os conflitos sociais eclodiriam como um grande sentimento de injustiça e pela percepção de que o pacto social, formulado em torno da liberdade, da propriedade e da dignidade igual para todos os cidadãos, não teria sido cumprido em sua totalidade. A busca por reconhecimento evidenciaria que o pacto $e$ as normas jurídicas e institucionais, que inicialmente $o$ assegurariam, foram somente o ponto de partida e a chegada não teria se efetivado.

O direito à identidade do ser mulher, ser negra, dotada de dignidade, constituir um valor em si mesma, acreditar ser pessoa única e insubstituível, sujeito histórico e autônomo passa pela superação material das injustiças no campo da saúde pública brasileira. Mais adiante Gislene Santos, com base em Honneth, assevera que:

É a identidade do sujeito que dever ser reconhecida para que ele se sinta em condições de participar da sociedade como igual. Sua identidade, por meio do respeito a seu corpo e cultura, sua identidade, por meio da não exclusão de seus direitos e sua identidade como pessoa portadora e executora de habilidades e talentos que podem ser estimados socialmente.

Com fulcro nas reflexões de Taylor $^{70}$, é o valor solidariedade que afirma e garante a vida em condições dignas de todos os seres humanos. Convém alertar que para o referido autor o reconhecimento é tema central no cenário político contemporâneo. Desse modo, o não reconhecimento da mulher negra, do seu direito à saúde e de suas diferenças resulta sim em ponto de fragmentação do todo social.

Citando Kymlicka, Gislene Santos aproxima as políticas multiculturais com as políticas de reconhecimento, que ultrapassam as fronteiras dos direitos tradicionalmente compreendidos porque oferecem uma atenção adicional de determinados grupos vulneráveis. A adoção de políticas que contemplem a

\footnotetext{
${ }^{70}$ TAYLOR, Charles. Argumentos Filosóficos. São Paulo: Loyola, 2000.
} 
diversidade étnica e de gênero impactam em maior ou menor grau a efetivação dos direitos fundamentais. 


\section{CAPÍTULO III - A POLÍTICA PÚBLICA DE PROMOÇÃO DO DIREITO À SAÚDE DA MULHER BRASILEIRA}

Para a finalidade de nossa pesquisa adotamos a concepção de que a Política Pública designa um conjunto de programas, ações, bens e recursos públicos destinados à garantia de direitos, sejam eles a liberdade e a igualdade ou a satisfação de necessidades básicas como emprego, educação, saúde, habitação, acesso à Justiça ou à terra.

A Política Pública é definida como um programa ou quadro de ação governamental, porque consiste num conjunto de medidas articuladas (coordenadas), cujo escopo é dar impulso, isto é, movimentar a máquina do governo, no sentido de realizar algum objetivo de ordem pública ou, na ótica dos juristas, concretizar um direito.

O tema das Políticas Públicas tem muitas interfaces. A primeira forma de visão abrange as análises para a formulação das políticas em si. A segunda, por sua vez, trata da produção de informação para os estudiosos de Ciência Política e a terceira é a própria aplicação dos modelos de Políticas Públicas. "Política pública" é um instituto presente na Ciência Política e na Administração. Faz menção a um conjunto de programas destinados à garantia de direitos.Maria Paula Dallari Bucci explicita a dificuldade de apropriação do conceito de políticas públicas no campo do direito: "definir as políticas públicas como campo de estudo jurídico é um movimento que faz parte de uma abertura do direito para a interdisciplinaridade. ${ }^{\prime 71}$ Apresentaremos dois modelos teóricos para a compreensão da formulação das políticas públicas segundo a eleição de Ana Cláudia N. Capella no artigo:

\footnotetext{
${ }^{71}$ BUCCI, Maria Paula Dallari. O conceito de política pública em direito.In: BUCCI, Maria Paula Dallari ( org.).Políticas públicas: reflexões sobre o conceito jurídico. São Paulo: Saraiva, 2006, p.2.
} 
"Perspectivas Teóricas sobre o Processo de Formulação de Políticas Públicas"72. O primeiro modelo é de Múltiplos Fluxos ((Multiple Streams Model) concebido por John Kingdon e o segundo é o Equilíbrio Pontuado (Punctuated Equilibrium Model) de Frank Baumgartner e Brian Jones. Na página 25, in verbis:

Kingdon considera as políticas públicas como um conjunto formado
por quatro processos: o estabelecimento de uma agenda de políticas
públicas; a consideração das alternativas para a formulação de
políticas públicas, a partir das quais as escolhas serão realizadas; a
escolha dominante entre o conjunto de alternativas disponíveis e,
finalmente, a implementação da decisão. Em seu modelo de multiple
streams, o autor preocupa-se especificamente com os dois primeiros
processos, chamados estágios pré-decisórios: a formação da
agenda (agenda-setting) e as alternativas para a formulação das
políticas (policy formulation). O conjunto de temas que recebe a atenção do governo e dos cidadãos é chamado de "agenda governamental" por Kingdon. Uma vez que os assuntos de interesse social são múltiplos e complexos, apenas alguns deles são contemplados pelos formuladores e gestores de políticas públicas. Esses temas são identificados na "agenda decisional", uma divisão da agenda governamental, e estão prontos para se transformarem em "políticas" (policies). A distinção é necessária porque as duas agendas são submetidas a diferentes influências e existem ainda agendas especializadas. Aplicando o modelo de Kingdon à nossa pesquisa, vislumbramos as agendas das políticas do direito à saúde, do direito à saúde da mulher e do direito à saúde da mulher negra. A mudança na agenda das políticas públicas é o resultado de três fluxos convergentes: os problemas (problems), soluções ou alternativas (policies) e política. (politics). Kingdon, segundo Capella, distingue "problemas" de "questões" (conditions). As questões transformam-se em problemas quando são percebidos pelos formuladores das políticas públicas que procuram agir

\footnotetext{
${ }^{72}$ CAPElla, Ana Cláudia N., Perspectivas Teóricas sobre o Processo de Formulação de Políticas Públicas In:

BIB, São Paulo, $n^{\circ} 61,1^{\circ}$ semestre de 2006, pp. 25-52
} 
a respeito. $\mathrm{Na}$ integração entre os direitos humanos e as políticas públicas a apresentação de pesquisas estatísticas e indicadores numéricos é mecanismo insuficiente para o reconhecimento da existência de violações. São as interpretações desses dados que demonstram um problema social concreto que exige atenção. Eventos, crises e símbolos podem prender a atenção dos formuladores de políticas públicas.

À guisa de exemplo desses mecanismos citados, o compromisso do Estado brasileiro na promoção de políticas de ações afirmativas destinadas à população negra e o reconhecimento no plano nacional e internacional do racismo vigente em nosso país por ocasião da 3a Conferência Mundial de Combate ao Racismo, Discriminação Racial, Xenofobia e Formas Correlatas de Intolerância ( Durban, 2001). Esse evento raramente eleva um assunto para o plano da agenda, entretanto, reforça a sensibilidade sobre um problema existente. O monitoramento das políticas públicas constitui o último desses mecanismos.

A observação dos investimentos, as atividades de implementação das políticas públicas e cumprimento integral ou parcial das metas, as denúncias de ações e omissões por parte das cidadãs e cidadãos destinatários podem monopolizar as atenções dos formuladores de políticas públicas.

Do ponto de vista de estratégia política, a definição do direito à saúde da mulher negra no município de São Paulo como um problema de política pública é de fundamental relevância. A maneira como esse problema é conceituado, articulado e concentrado pelos agentes formuladores de políticas públicas pode redundar no sucesso dessa questão no processo muito competitivo da formação da agenda.

No segundo fluxo (policy stream) verificamos um conjunto de alternativas e soluções disponíveis para determinado problema. Porém, Capella parafraseando 
Kingdon, alerta que os problemas e as soluções não emergem aos pares, simultaneamente. Nessa compreensão, as soluções nascidas no interior das comunidades (policy communities) "flutuam" em um "caldo primitivo de políticas" (policy primeval soup). As soluções dotadas de maior viabilidade técnica e de custo social mais tolerável remanescem para o exame efetivo dos participantes do processo decisório das políticas públicas. Os pesquisadores, os agentes públicos e os representantes políticos compõem as comunidades geradoras de alternativas (policy communities) e partilham de uma preocupação de área (policy area). A proposta de solução classificada como viável é difundida tanto para sensibilizar os destinatários das políticas públicas quanto a população em geral. O processo de sensibilização (soften up) decorre da percepção de que as propostas só serão seriamente consideradas se toda a sociedade for persuadida de sua importância.

A difusão sofre um efeito multiplicador (bandwagon), as ideias são disseminadas e ganham apoiadores. A comunidade interessada na política pública não prescinde, obrigatoriamente, de um consenso sobre a seleção das propostas. Em verdade, é o bastante o reconhecimento de que algumas propostas apresentadas ganham em relevância em comparação às demais.

O terceiro fluxo das políticas públicas é o da "política propriamente dita" (politics stream). Esse fluxo, na lição de Kingdon, apresenta dinâmica particular composta por três elementos: o primeiro é o "clima" ou "humor" nacional (national moodino), que é identificado com uma situação em que diferentes pessoas compartilham de idêntica questão durante um determinado período de tempo. No contexto das lutas do Movimento de Mulheres Negras, do Movimento Negro e do Movimento de Reforma da Saúde anteriores à Constituição de 1988, observamos o 
"clima" para a criação de ações e políticas de garantia do direito à saúde da população negra e das mulheres negras.

O segundo elemento do fluxo político é formado pelas forças organizadas politicamente, os "grupos de pressão". O apoio ou a oposição dessas forças políticas pode resultar na defesa ou no abandono da política pública. Derradeiramente, o último fator que incide sobre a agenda das políticas públicas é a mudança no interior da própria estrutura governamental: mudança no Poder Executivo, renovação das casas legislativas, alterações nos postos diretivos de órgãos e empresas públicas.

Um novo governo é a oportunidade mais favorável para as mudanças na agenda. A mudança na atribuição de competências entre ministérios, secretarias e comitês pode acrescentar ou excluir questões. Em casos específicos, os três fluxos: o "humor" nacional, as soluções e a dinâmica política são reunidos para a realização da mudança de agenda das políticas públicas. As janelas de políticas públicas (policy windows) são as circunstâncias que viabilizam a convergência dos fluxos. Os fluxos de problemas (problems stream) e o fluxo político (politics stream) influenciam tais janelas. Conforme esse modelo, o fluxo de soluções (policy stream) não causa impacto direto na agenda pública. Em realidade, as propostas de soluções e alternativas formuladas pelas comunidades (policy communities) aparecem na agenda somente quando os problemas são percebidos ou as demandas sociais criam o ambiente para o diálogo.

Mudanças na agenda de políticas públicas acontecem na convergência ou junção dos três fluxos (coupling). O coupling (nomenclatura de Kingdon), por seu turno, ocorre nos momentos de abertura das janelas de políticas públicas (policy windows). A convergência ou junção é pontuada pela transitoriedade. As 
oportunidades de mudança na agenda pública podem findar em curto lapso temporal em razão de eventos desejados ou não pelos especialistas e/ou destinatários das políticas públicas. Há outro componente essencial : a atividade dos empreendedores de políticas (policy entrepeneurs). Essas pessoas podem ocupar postos estratégicos no Poder Executivo, podem ser parlamentares ou fora do aparelho do Estado, membros da comunidade acadêmica ou do movimento social organizado. Um(a) empreendedora de políticas públicas liga as soluções aos problemas, as propostas aos momentos políticos e os eventos da política aos problemas sociais $^{73}$.

$\mathrm{Na}$ proposta de Kingdon, alguns atores sociais influenciam a definição das políticas públicas, outros, por outro turno, trabalham na definição das alternativas (decision agenda). Os primeiros são denominados "atores visíveis" posto que considerados pela imprensa e pela sociedade os responsáveis pelo manejo dos recursos institucionais, organizacionais e de comando. No outro extremo temos os "participantes invisíveis", componentes das comunidades geradoras de políticas. Os agentes políticos do Poder Executivo, os parlamentares, os grupos de interesse, os veículos de comunicação social e a opinião pública recebem a designação de "atores visíveis" pois são contemplados em maior ou menor grau na agenda governamental. O Chefe do Poder Executivo federal recebe destaque nesse modelo, no entanto, o Presidente não possui condições de controlar o resultado final de uma política pública. Os titulares de Ministérios e de Secretarias Executivas auxiliam na focalização de questões sociais já existentes. À semelhança da ação presidencial, os agentes políticos da alta burocracia do governo exercem pouco ou

\footnotetext{
${ }^{73}$ CAPELLA, Ana Cláudia N., op. cit. p.31.
} 
nenhum controle sobre a seleção e implementação das soluções em políticas públicas.

No Poder Legislativo, as/os parlamentares tem o dever de criar dispositivos legais para a viabilização de mudanças. Suas atuações nas casas legislativas, a publicidade de suas falas nas tribunas e participações em grupos e comissões temáticas explicitam o seu interesse na agenda pública. Outro fator apontado por Kingdon é a estabilidade das/dos parlamentares em comparação com as/os ocupantes de postos na administração pública direta ou indireta. Essa estabilidade deve ser relativizada pois as/os legisladoras/es almejam a satisfação de seu eleitorado, posições de destaque e prestígio em detrimento de outros/as parlamentares e a defesa das suas posições partidárias.

Os partidos políticos podem levar uma questão para a agenda explicitada em seu programa de governo. Porém, a plataforma de governo da campanha políticoeleitoral pode não ser reproduzida quando um grupo político assume e exercita o poder. A liderança na casa legislativa e a coalização de forças políticas da campanha eleitoral influenciam a agenda definida na esfera de governo. As peças e promessas em tempos de disputa eleitoral não garantem a ocorrência de mudança de agenda.

Ao lado dos participantes do processo político-eleitoral, consideramos os grupos de interesses centrados no setor industrial, no setor de serviços, categorias profissionais e lobistas. Alguns desses grupos atuam de forma positiva nas ações governamentais, em contrapartida, outros obstruem a implementação das políticas e até mesmo o agir de outros atores. Finalmente, o último ator visível é a imprensa. A importância da imprensa varia conforme o tipo de participante na formulação da agenda de políticas públicas. Quanto maior o poder decisório no âmbito do Estado, 
menor será o círculo de influência dos veículos de comunicação social. A despeito do seu papel indireto, a imprensa amplifica questões relativas à agenda já positivada. Os meios de comunicação não criam questões, no entanto, aceleram o desenvolvimento de políticas públicas ou aumentam o seu poderio.

O grupo dos "participantes invisíveis" influenciam o processo de criação e implementação de alternativas. A organização hierárquica favorece a centralização da agenda. Os servidores públicos estão concentrados na administração das políticas públicas existentes e auxiliam nos aspectos técnico-burocráticos os agentes políticos.

A comunidade acadêmica constitui o segundo grupo de "participantes invisíveis", age na criação de soluções alternativas. Ideias oriundas de pesquisas científicas são apresentadas aos demais atores para modificar a política pública vigente. Esse grupo de acadêmicas/os, pesquisadoras/es e consultores/as é convidado a participar e opinar nas instâncias dos Poderes Executivo e Legislativo, espaços de decisão.

Um outro modelo de agenda-setting desenvolvido para o exame das políticas públicas, o modelo do equilíbrio pontuado (Punctuated Equilibrium Model), de autoria de Baumgartner e Jones é complementar às ideias de Kingdon anteriormente apresentadas.

Nos dizeres de Baumgartner e Jones, períodos longos de estabilidade em que as transformações sociais são lentas e lineares sofrem interrupções bruscas (punctuations). Isso se aplica perfeitamente às agendas públicas que mudam rapidamente após um feedback positivo. Novos pontos da agenda ganham popularidade e ocupam o espaço das antigas demandas políticas. Os governos delegam parcelas de autoridade na formulação e implementação de políticas 
públicas para determinados agentes burocráticos inseridos em subsistemas. Nessa divisão, as lideranças governamentais cuidam de questões proeminentes e os agentes especialistas, das paralelas.

No interior dos subsistemas pode ocorrer o monopólio de políticas voltadas para um único interesse (policy monopoly). No monopólio as/os detentores/as do poder de decisão compartilham as mesmas ideias sobre uma questão específica. Dois fatores definem e constituem o monopólio de políticas: a estrutura definida institucionalmente que permite ou proíbe o acesso ao processo decisório e uma ideia densamente associada com a instituição e com os valores políticos comunitários. Para melhor compreensão dos momentos de estabilidade e mudança das políticas públicas os autores conceberam o conceito de policy image.

$\mathrm{Na}$ imagem da política pública temos as ideias que permitem o entendimento desse arranjo por parte dos membros da comunidade e contribuem para a difusão das questões. A imagem da política pública tem dois componentes: informações empíricas e apelos emotivos (tone). Baumgartner e Jones afirmam que "apelos emocionais" podem atrair ou repelir a mobilização social em torno de uma questão. A exemplo de Kingdon, os autores compreendem que um problema político e/ou social é incapaz de, sozinho, se transformar em solução em matéria de política pública.

A criação de uma boa imagem é elemento estratégico para a atenção dos agentes governamentais, competentes para transformar as questões em problemas presentes na agenda. Os formuladores das políticas públicas aplicam considerável empenho na construção da policy image mesmo sem exercerem qualquer controle sobre a percepção dessa imagem na sociedade. 
No nosso estudo, a imagem da política pública de direito à saúde da mulher negra exerce dupla função: assegura o entendimento comum sobre a questão ao mesmo tempo que procura influenciar as instituições e indivíduos que possuem autoridade sobre o tema. O direito à saúde da mulher negra no município de São Paulo está associada às competências de várias instâncias: Ministério da Saúde, Secretária da Saúde do Estado de São Paulo e Secretária Municipal de Saúde, para citar as principais. Esses locais institucionais recebem o nome de policy venue (arenas políticas em que as decisões são oficializadas).

Uma das instituições responsáveis pela formulação e execução da política pública de direito à saúde da mulher negra pode ser refratária à policy image, já outra pode aceitar a imagem sem qualquer óbice. As mudanças são lentas e graduais nos subsistemas das políticas públicas constituindo um panorama de equilíbrio, apoiada por um monopólio de políticas, uma imagem partilhada e questões limitadas ao subsistema (feedback negativo). Algumas decisões no âmbito dos subsistemas derivam de um número reduzido de atores que possuem um único entendimento sobre uma questão específica, constroem monopólios, limitam o ingresso de novos participantes e vedam o surgimento de novas ideias. Esses subsistemas são estáveis e as propostas de mudanças são pouco estimuladas. Nos momentos mais críticos, o equilíbrio pode ser marcado por períodos de mudanças velozes. Tal fenômeno ocorre na ruptura dos limites do subsistema por parte de uma questão até o seu estabelecimento no macrossistema político/agenda governamental (Kingdon). Os macrossistemas políticos mudam rápida e intensamente, abarcam diferentes concepções sobre a mesma política pública e feedback positivo. A mudança no macrossistema leva à introdução de novas ideias e novos atores no subsistema. Essas ideias e atores novos permanecem por certo 
período de tempo (policy legacy), geram um diferente estado de equilíbrio no subsistema que regressa à condição de estabilidade.

Os dois modelos de estudo das políticas públicas aqui apresentados consideram o processo decisório sob a ótica do pós-positivismo. Ambos os modelos analisam as ações individuais das/dos empreendedores de políticas públicas quanto a própria organização político-administrativa do Estado, auxiliando na percepção de oportunidades e restrições para a concretização de mudanças sociais.

A Política Pública, em resumo, designa um conjunto de programas, ações, bens e recursos públicos destinados à garantia de direitos e a satisfação de necessidades. Há uma semelhança entre Política Pública e Serviço Público. A expressão "serviço público" pode ter várias acepções. Pode designar todos os serviços públicos prestados pelo Estado, inclusive os diretos e exclusivos (exemplos: segurança pública, poder de polícia etc.); os serviços públicos delegáveis (exemplos: fornecimento de água energia elétrica etc.) e os serviços prestados na exploração de atividade econômica ( exemplos: serviços prestados por bancos estatais).

As políticas públicas são demarcadas em três modalidades básicas:

a) distributivas: caracterizadas pelos recursos dispensados sem limitações e a facilidade com que podem ser desagregadas, sem obediência a critério geral e universalista;

b) regulatórias: apresentam impactos específicos e individualizados, elevam custos ou reduzem a atuação de agentes privados, embora as decisões sobre a alocação de recursos seja baseada em leis e regulamentos gerais e

c) redistributivas: são aquelas que abrangem relações entre categorias sociais e envolvem grandes contingentes de pessoas. 
O Monitoramento e a avaliação de políticas públicas são as duas dimensões fulcrais para a efetividade dos direitos humanos. "A execução (da política pública) deverá ser sempre transversal, democrática e descentralizada"74. O Monitoramento exige a capacidade de acompanhamento das ações perpetuadas pelas instituições executoras. Os executores terão o dever de disponibilizar as informações pertinentes às conquistas e dificuldades no exercício das políticas. Essa dimensão é atribuída às cidadãs e aos cidadãos, seja intermediada por organizações da sociedade civil, seja pela ampla divulgação das informações nos meios de comunicação social.

A avaliação considerará a investigação do impacto da política, entendido como o efeito integrado de todas as ações, por meio de indicadores sociais: educação, trabalho, saúde, segurança etc. A definição da metodologia de cálculo, das fontes e da periodicidade desses indicadores é o desafio inicial para o sucesso desse empreendimento. Os indicadores eleitos precisam ser hábeis para medir o impacto da política pública sobre a realidade social. É obrigatória a periodicidade da avaliação para que os resultados auxiliem os gestores no aperfeiçoamento da política e potencializem a participação da sociedade civil.

\footnotetext{
${ }^{74}$ SILVA JR, Hédio. A gestão e o controle social de políticas públicas In: Políticas Públicas de Promoção da Igualdade Racial. Organização Hédio Silva Júnior, Maria Aparecida da Silva Bento, Rogério Silva; vários autores. São Paulo, SP: CEERT, 2010. p.189.
} 


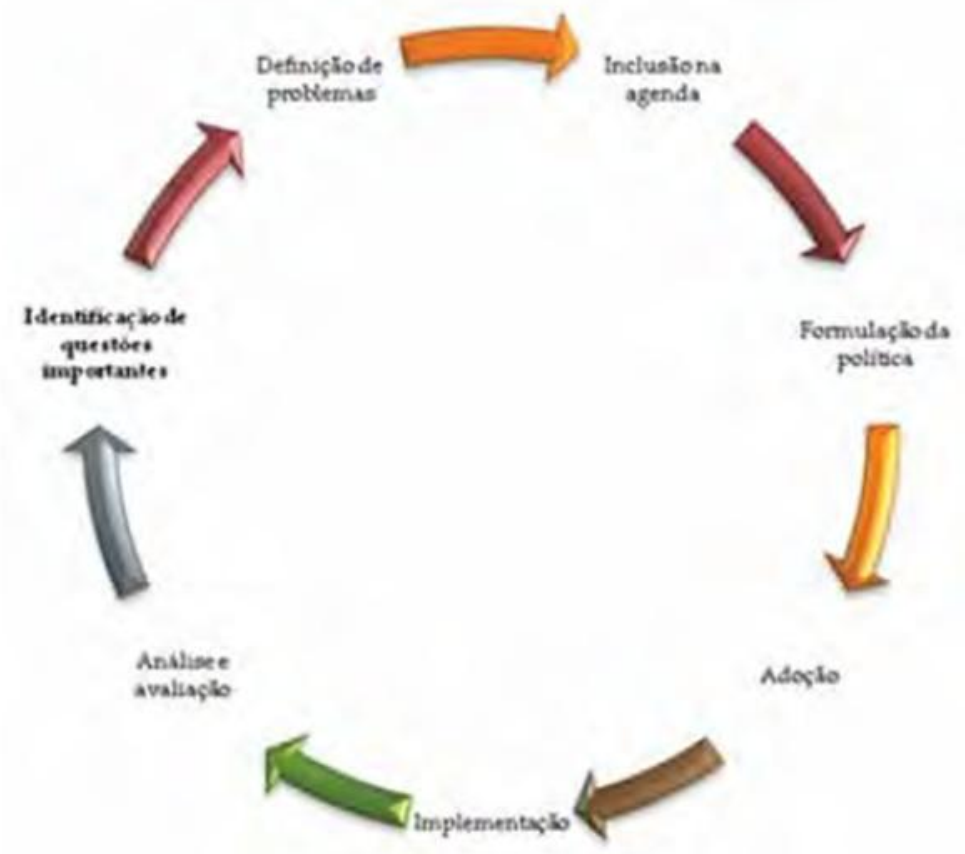

Figura 1:Processo de formulação e desenvolvimento de políticas públicas

Fonte: PATROCLO, Maria Aparecida de Assis. As múltiplas facetas da interação entre pesquisa e o processo de formulação de política pública e ou intervenção em saúde pública, tese (doutorado)Escola Nacional de Saúde Pública Sérgio Arouca. Rio de Janeiro, 2011. 222f.:il.graf. In: Saúde da mulher negra: guia para a defesa dos direitos das mulheres negras / Articulação de Organizações de Mulheres Negras Brasileiras. - Porto Alegre, 2012.

Antes do estudo dos direitos humanos das mulheres e a política pública para as mulheres, devemos compreender a noção de gênero para a afirmação e proteção desses direitos. Joan Scott esclarece a historicidade do gênero e a sua matiz relacional entre homens e mulheres ${ }^{75}$. Em tempos da Revolução Francesa, Olympe de Gouges, no ano de 1791, um texto intitulado "Os Direitos da Mulher e da Cidadã", abordando a situação da mulher, esquecida no ideário de liberdade e igualdade pautado no universo masculino ${ }^{76}$. Adotaremos a concepção de que gênero é elemento constitutivo das relações sociais, uma construção fruto da História e da Sociedade. O gênero é construído e alimentado por símbolos, normas e instituições (família, escola, organizações religiosas, Estado e mercado de

\footnotetext{
${ }^{75}$ SCOTT, Joan. Gênero, uma categoria útil de análise histórica. Educação e Realidade. Porto Alegre, v. 16, n.2, jul-dez, 1990.

${ }^{76}$ Declaração dos direitos da mulher e da cidadã.
} 
trabalho) que determina modelos comportamentais adequados (ou não) para mulheres e homens. O gênero é categoria social que se baseia em características biológicas dos seres humanos.

O conceito de gênero faz menção à construção social do sexo biológico. $O$ gênero diz respeito às maneiras diversas em que homens e mulheres exercem seus papeis sociais em inúmeros contextos. O uso do conceito de gênero abandona a explicação biológica como a responsável pelos comportamentos e lugares das mulheres e dos homens na vida em sociedade. Além disso, gênero enfatiza os aspectos social, e cultural das distinções baseadas no sexo, afastando a naturalização das diferenças entre mulheres e homens, naturalização que propaga a falsa impressão de assimetria e de hierarquia entre os sexos. A categoria gênero abarca a dimensão das relações e disputas de poder; realça o aspecto relacional entre as mulheres e os homens, ou seja, a existência e a concepção de mulher e de homem são intrínsecas e indissociáveis ${ }^{77}$.

A Convenção sobre a eliminação de todas as formas de discriminação contra a mulher adotada pela ONU em 18 de dezembro de 1979 (CEDAW) e ratificada pelo Brasil em fevereiro de 1984, é fundamentada na consciência de que a discriminação contra a mulher é uma violação dos princípios da dignidade humana e da igualdade de direitos dentre outros temas e a necessidade de revisão das legislações nacionais no sentido de promover os direitos humanos de meninas e mulheres. A discriminação contra a mulher constitui um óbice ao integral desenvolvimento das suas potencialidades e um obstáculo ao bem-estar de seu país e da humanidade. Consoante o artigo $1^{\circ}$ da CEDAW, discriminação contra a mulher é:

\footnotetext{
${ }^{77}$ SOIHET, Rachel e PEDRO, Joana Maria. A emergência da pesquisa da História das Mulheres e das Relações de Gênero. In: Revista Brasileira de História. São Paulo, v. 27, no 54, p. 281-300 - 2007.
} 
Toda e qualquer distinção, exclusão ou restrição baseada no sexo e que tenha por objeto ou resultado prejudicar ou anular $o$ reconhecimento, gozo, exercício pela mulher, independentemente de seu estado civil, com base na igualdade do homem e da mulher, dos direitos humanos e das liberdades fundamentais nos campos político, econômico, social, cultural e civil ou em qualquer outro campo.

O Brasil na qualidade de estado signatário tem o dever de eliminar de maneira progressiva a discriminação e promover a igualdade de gênero.

Mais adiante a CEDAW em seu artigo 4ํำ prevê a adoção de ações afirmativas para a aceleração da igualdade material entre homens e mulheres e tais medidas não serão consideradas discriminação nos termos da Convenção. No rol de direitos humanos das mulheres é importante realçar os direitos sexuais e reprodutivos e a questão da violência doméstica e familiar. A Conferência Internacional sobre População e Desenvolvimento da cidade do Cairo (1994) elevou os direitos sexuais e reprodutivos à categoria de direitos humanos. No ano de 1995, em Beijing, houve a IV Conferência Mundial sobre a Mulher, o Desenvolvimento e a Paz. Nessa oportunidade houve a renovação do caráter de direitos humanos das questões de maternidade, gestação, contracepção, aborto. Para tratarmos da política pública de promoção do direito à saúde da mulher brasileira há necessidade de apresentarmos os diferentes sistemas de gênero - masculino e feminino - e as relações sociais de poder entre homens e mulheres resultantes da cultura, em especial a brasileira.

\subsection{O direito das mulheres nas constituições brasileiras}


O movimento de mulheres no $\mathrm{Brasil}^{78}$ mudou a exemplo do feminismo mundial: de sufragista e emancipacionista do século $X X^{79}$ até o ressurgimento ${ }^{80}$ nos anos 1960 ao lado de outros movimentos sociais: o movimento estudantil da França (maio de 1968), a luta pelos direitos civis nos Estados Unidos da América (EUA), a bandeira pacifista contra a Guerra do Vietnã e o movimento hippie. Iniciamos este tópico com o exame do tratamento constitucional destinado às mulheres brasileiras desde os tempos imperiais.

A Constituição imperial de 1824 não considerava nem as mulheres e nem a população negra escravizada no corpo da cidadania, os dois grupos sociais eram vítimas de exclusão política.

A primeira constituição republicana (1821) foi fortemente influenciada pela Constituição dos Estados Unidos da América. A mulher brasileira não era considerada titular de direitos.

A Constituição da República Nova foi promulgada após o chefe do Governo Provisório, Getúlio Vargas, que governou o país por decreto desde a Revolução de 1930 até 1933, após a derrota da Revolução Constitucionalista de 1932. O aumento do campo da matéria constitucional foi ambicioso ao introduzir a ordem econômica e social, a família, a educação e a cultura. Tinha como principais inovações a introdução do voto secreto e o sufrágio feminino, a criação da Justiça do Trabalho, definição dos direitos constitucionais do trabalhador (jornada de 8 horas diárias, repouso semanal e férias remuneradas) e previdência social. Porém, os embates

\footnotetext{
${ }^{78}$ As primeiras ideias feministas são trazidas ao Brasil por Nísia Floresta Brasileira Augusta. Pioneira da primeira onda feminista em nosso país, conviveu com as feministas europeias em viagem de estudos e no regresso ao país defendeu a emancipação feminina pela educação.

${ }^{79}$ No Brasil, destaca-se a liderança de Bertha Lutz, principal responsável pela manutenção da luta sufragista $\mathrm{O}$ voto feminino é conquistado no Brasil em 1932 e é incorporado à Constituição de 1934.

${ }^{80} \mathrm{O}$ movimento feminista brasileiro ressurgido nos anos 1970 recuperou uma antiga prática do movimento: a realização de encontros e debates. Inicialmente sob a forma de seminários restritos ou encontros paralelos dentro das reuniões anuais da Sociedade Brasileira para o Progresso da Ciência (SBPC).
} 
ideológicos, rixas regionais, obstáculos à sucessão presidencial e outros fatores fulminaram o diploma constitucional perante o golpe de Estado.

$\mathrm{Na}$ constituinte de 1934, dois anos após autorização do governo federal, houve uma representante do sexo feminino, a primeira deputada do Brasil: Carlota Pereira de Queirós.

Entretanto, no mesmo plano federal, as mulheres foram excluídas, pois houve uma postura legal de viés patriarcal nas Constituições de 1937 e 1967, bem como na Emenda Constitucional de 1969.

O reconhecimento dos trabalhadores da zona urbana e a inclusão do eleitorado feminino como cidadãos plenos e destinatários de prerrogativas legítimas eram objetos de articulação, organização e patrocínio estatal, ou seja, o autoritarismo promoveria a integração de mulheres e trabalhadores no Brasil moderno. No cenário de insatisfação nacional com o incremento das desigualdades sociais, o governo da época aplicou medidas satisfatórias de interesses da classe trabalhadora (a histórica política do pão e circo), mas retirou-lhes a total autonomia.

As mulheres brasileiras, apesar da exclusão constitucional citada engajaramse em lutas em prol de sua cidadania nos anos 1950. Cabe ressaltar a campanha em prol da modificação dos dispositivos do Código Civil de 1916, que positivaram a condição de inferioridade feminina.

O Estatuto da Mulher Casada (1962) foi o fruto dessa luta específica, neste diploma legal a mulher casada teria plena capacidade aos 21 anos e seria tratada como colaboradora do marido nos encargos da família.

A Lei do Divórcio foi promulgada em 1977, outra conquista do movimento organizado de mulheres. Nas décadas de 1960 e 1970, o movimento feminista foi consolidado na Europa e nos Estados Unidos, muito estimulado pela agitação 
política e cultural que essas regiões passavam no período, que questionavam o conservadorismo estrutural da sociedade. O ano de 1975 é crucial para o debate da discussão da condição feminina no plano internacional com a Declaração do Ano Internacional da Mulher pela Organização das Nações Unidas (ONU).

Em terras brasileiras, o quadro era bem peculiar, pois nosso país vivia sob um regime de exceção/repressão assim como as demais nações latino-americanas. O feminismo militante no Brasil aparece como consequência da resistência das mulheres à ditadura militar, depois da derrota das que escolheram as armas.

A participação feminina na luta armada, segundo Cynthia Andersen Sarti ${ }^{81}$, representou a quebra do modelo esperado e destinado às mulheres nos anos 1960 e 1970. Mesmo sem uma proposta feminista propositalmente criada, as militantes desprezavam o lugar tradicional da mulher ao adotarem um comportamento questionador do matrimônio e uma postura "masculina" de "pegar em armas" e obter êxito nesse empreendimento. A igualdade de gêneros na militância era reconhecida apenas teoricamente. Já no período democrático o espaço acadêmico apresentou a mulher como protagonista da resistência à ditadura e ao mesmo tempo vítima de uma modalidade específica de violência baseada na concepção do "ser mulher" na sociedade brasileira. $O$ corpo feminino foi ferido, torturado, mães e filhos manipulados por sua vulnerabilidade e dor. A divulgação e o exame dos depoimentos das vítimas da ditadura militar em eventos, artigos científicos e matérias jornalísticas fundamenta uma leitura própria do feminismo brasileiro a partir dos anos 1970.

Após o reconhecimento oficial da ONU da questão feminina como uma questão de toda a sociedade permitiu a formação e exposição pública de grupos

\footnotetext{
${ }^{81}$ SARTI, Cynthia Andersen. O feminismo brasileiro desde os anos 1970: revisitando uma trajetória. Estudos Feministas, Florianópolis, 12(2): 35-50, maio-agosto/2004.
} 
políticos de mulheres que atuavam de modo clandestino. O feminismo brasileiro da época era próprio das classes médias e ampliou-se com a aliança com os setores populares da sociedade e as organizações de bairro. Essa articulação de feministas com as camadas mais simples passou por um laço delicado com a Igreja Católica, também ator de resistência ao regime de exceção.

As feministas organizadas nos bairros participavam dos trabalhos pastorais calcados na Teologia da Libertação. Houve uma aliança entre o feminismo, os grupos políticos de esquerda e a Igreja Católica para o enfrentamento do regime autoritário. Os pontos divergentes sobre os direitos sexuais e reprodutivos das mulheres: exercício da sexualidade, casamento, planejamento familiar e aborto foram relegados aos espaços privados, sem acesso ao grande público.

Outra característica do movimento feminista brasileiro é o seu relacionamento com o Estado. Ao lado dos movimentos sociais das periferias pobres as organizações feministas pleiteavam direitos sociais (fornecimento de água, energia elétrica, calçadas e saneamento básico) tendo como norte o círculo social da mulher e suas condições de vida em família e no bairro. Essas reivindicações femininas nos movimentos de bairro constituíram mais um elemento para o debate da condição da mulher brasileira.

O movimento feminista expandiu as suas ideias para o movimento de mulheres em geral, sobrepujando as primeiras impressões de cunho pejorativo. Para os setores conservadores, o feminismo era um movimento de moral duvidosa e um perigo em si mesmo. Por outro lado, os setores de esquerda associavam a luta feminista aos valores burgueses. Houve até um conflito de denominações: "feminismo x feminino" entre as próprias militantes, provocando divisões. 
A identificação "feminista" sinaliza a percepção de que os problemas específicos de meninas e mulheres exigem tratamento diferenciado, muito além das mudanças socioeconômicas.

A unidade do movimento de mulheres perdurou até a redemocratização. $\mathrm{Na}$ abertura política duas correntes foram identificadas: a primeira, centrada na atuação feminina no espaço público e no debate sobre o direito, a saúde, a educação e o mercado de trabalho. Essa tendência influenciou a formulação de políticas públicas para a construção e garantia dos direitos humanos das mulheres. A segunda concentrou-se nos estudos da subjetividade feminina. No começo dos anos 1980 , com a anistia política e o retorno das militantes exiladas, o feminismo brasileiro recebe as contribuições do movimento na Europa. As ideias feministas (gênero e opressão sobre a mulher) espalharam-se por todas as regiões do nosso país e por muitos segmentos sociais (sindicatos, partidos políticos etc.). Paralelamente à difusão da bandeira feminista, Sarti observa o surgimento de grupos de perfil técnico e especializado em políticas públicas. Muitas organizações de mulheres adotaram o regime jurídico de Organizações Não Governamentais (ONGs).

A especialização feminista também foi verificada no espaço acadêmico com a criação e manutenção de linhas de pesquisa, agências financiadoras e o interesse do mercado editorial sobre a temática da mulher.

A Convenção sobre a Eliminação de todas as formas de Discriminação contra a Mulher (CEDAW), adotada pela ONU em 18 de dezembro de 1979 e ratificada pelo Brasil em 1984, tem seu fundamento nos princípios da igualdade de direitos, no respeito da dignidade humana e na consciência de que qualquer obstáculo à participação da mulher na vida política, social econômica e social é um obstáculo ao bem estar e ao desenvolvimento de um país e da Humanidade. Anotamos aqui 
algumas medidas tomadas pelo Estado brasileiro anteriores à Constituição de 1988 para eliminar a discriminação contra a mulher: conselhos da condição feminina criados em todos os níveis da administração pública e delegacias próprias para as ocorrências de violência contra a mulher. Cabe lembrar que a igualdade entre mulheres e homens foi trazida no texto constitucional apenas em 1988.

A Constituição de 1988 garantiu às mulheres, expressamente, o direito à igualdade, nos termos do artigo $5^{\circ}$, inciso I, assegurando a cidadania plena do ponto de vista formal. O sucesso do movimento de mulheres na esfera constitucional é expresso claramente nas normas que asseguram além da igualdade entre homens e mulheres mencionada; a igualdade entre mulheres e homens na família (artigo 226, parágrafo 5ำ); o reconhecimento da união estável como entidade familiar (artigo 226, parágrafo $3^{\circ}$, regulamentado pelas Leis 8.971 , de 29 de dezembro de 1994 e 9.278, de 10 de maio de 1996); a vedação da discriminação no mercado de trabalho, por motivo de sexo ou estado civil (artigo $7^{\circ}$, inciso $\mathrm{XXX}$, regulamentado pela Lei 9.029, de 13 de abril de 1995, que impede a exigência de atestados de gravidez e esterilização e outras práticas discriminatórias para admissão ou permanência no mercado de trabalho); a proteção especial da mulher via incentivos específicos (artigo 7ำ, inciso XX, regulamentado pela Lei 9.799, de 26 de maio de 1999, que encarta na Consolidação das Leis do Trabalho regras sobre o acesso da mulher ao mercado de trabalho); o planejamento familiar de livre decisão do casal, reverberando no dever estatal de propiciar recursos educacionais e científicos para o exercício desse direito (artigo 226, parágrafo 7ํㅡ, regulamentado pela Lei 9.263, de 12 de janeiro de 1996, que versa sobre o planejamento familiar no Sistema Único de Saúde; o dever do Estado de prevenir e punir a violência doméstica e familiar (artigo 226, parágrafo 8ํㅜㄹ prevendo a notificação compulsória em todo o território 
nacional, de episódios de violência contra a mulher que receber atendimento nos estabelecimentos de saúde públicos ou privados, conforme a Lei 10.778, de 24 de novembro de 2003.

Ressalte-se que o ordenamento jurídico brasileiro não respondia satisfatoriamente à realidade porque não oferecia proteção às mulheres e nem previa punição adequada aos agressores. As hipóteses de violação da integridade física e psicológica da mulher nas relações interpessoais eram classificadas como lesão corporal leve, ameaça e injúria. O Código Penal trazia como circunstância agravante de pena a condição pessoal de pai, filho, irmão ou cônjuge. Entretanto, o Poder Judiciário não aplicava o artigo para conter a complexidade da violência doméstica em seus diversos aspectos e tipos de relações sociais e afetivas. Com a Lei no 9099/1995 que criou os Juizados Especiais Cíveis e Criminais (JECRIMs) a situação se agravou, pois a maior parte dos crimes contra a mulher passou a ser encaminhada para os JECRIMs e tratado da mesma forma que as demais infrações de menor potencial ofensivo. Grande parcela dos processos eram arquivados ou os agressores recebiam como "punição" penas alternativas, cenário que contribuiu para um sentimento de impunidade. Em 7 de agosto de2006, foi adotada a Lei 11.340 - a Lei "Maria da Penha" -, que de modo pioneiro inédita criou mecanismos para a prevenir e punir a violência doméstica e familiar contra a mulher, assegurando medidas para a prevenção, assistência e proteção às mulheres em situação de violência. O panorama nacional aliado aos compromissos internacionais assumidos pelo Estado Brasileiro evidenciaram a urgência da efetivação dos direitos humanos das mulheres.

A CEDAW é o documento internacional mais importante para a defesa dos direitos das mulheres. Conforme o artigo 5ํㅜ o parágrafo $2^{\circ}$ tem status constitucional 
no Brasil. Em 1999, a Assembleia Geral da ONU adotou o Protocolo Facultativo à Convenção sobre a Eliminação de Todas as Formas de Discriminação Contra a Mulher, ratificado pelo Congresso Nacional em 2002. Esse Protocolo é uma garantia internacional dos direitos das mulheres nas hipóteses de falhas ou omissões no plano doméstico.

A Convenção Interamericana para Prevenir, Punir e Erradicar a Violência contra a Mulher, conhecida como "Convenção de Belém do Pará", foi adotada pela Assembleia Geral da Organização dos Estados Americanos (OEA) no ano de 1994 e ratificada pelo Brasil em 1995. A Convenção de Belém do Pará define a violência contra a mulher como toda ação baseada no gênero que resulte em morte, dano ou sofrimento físico, sexual ou psicológico à mulher no espaço público ou no âmbito de suas relações interpessoais.

No mesmo ano de 1995, o Brasil firmou compromisso com a Declaração e a Plataforma de Ação da IV Conferência Mundial sobre a Mulher em Beijing, documento político que preceitua o direito à igualdade das mulheres de todas as idades e classes sociais. A Plataforma traz o reconhecimento da atuação das mulheres no desenvolvimento econômico e a necessidade de ações de combate à pobreza, valorização do trabalho remunerado feminino e especial proteção à mulher no ambiente doméstico. Merece destaque a previsão de ações de assistência social das mulheres vítimas de violência e a reabilitação dos agressores.

A Conferência Internacional sobre População e Desenvolvimento realizada na cidade do Cairo adotou um Programa de Ação da Conferência. A Conferência do Cairo consagra os direitos sexuais e reprodutivos na categoria dos direitos individuais de mulheres e homens. 
Na leitura de Flávia Piovesan os direitos reprodutivos ${ }^{82}$ abrangem:

a) o direito decidir sobre a reprodução sem padecer discriminação, coerção ou violência; b) o direito de decidir de maneira livre $e$ responsável sobre o número de filhos e o intervalo entre seus nascimentos; c) o direito a ter acesso a informações e meios seguros, disponíveis e acessíveis de contracepção e d) o direito de acessar o padrão mais elevado de saúde reprodutiva.

E os direitos sexuais significam:

a) o direito a decidir responsável e livremente sobre o exercício de sua sexualidade; b) o direito controlar o próprio corpo; c) o direito de viver de modo livre a sua orientação sexual, sem represálias na forma de discriminação, coação ou violência; d) o direito à educação sexual; e) o direito à privacidade; f) o direito de acesso às informações e aos meios para fruir do mais alto padrão de saúde sexual e g) o direito a ter o benefício dos avanços da ciência e a consentir livremente à experimentos, com os devidos cuidados e ética recomendados pelos instrumentos internacionais

Em síntese, os direitos reprodutivos são direitos humanos das mulheres, pois dotados dos atributos da indivisibilidade, da imprescritibilidade e da universalidade. O direito à saúde reprodutiva além do aspecto corpóreo, diz respeito ao direito ao desenvolvimento e ao valor dignidade humana. Por sua vez, os direitos sexuais versam sobre a livre expressão da sexualidade humana, incluindo o direito à assistência à saúde e educação sexual.

Lucila Scavone ${ }^{83}$ sustenta que a noção dos direitos reprodutivos sofreu grande expansão no movimento feminista mundial na metade da década de 1980, após o Congresso Internacional de Saúde e Direitos Reprodutivos (Amsterdã, 1984). Para o movimento feminista os direitos reprodutivos possuíam uma dupla face: questionadora das relações de gênero no âmbito privado e orientadora das políticas de planejamento familiar vigentes. No Brasil o debate dos direitos

\footnotetext{
${ }^{82}$ PIOVESAN, Flávia. "Os direitos humanos da mulher na ordem internacional". In: Temas de Direitos Humanos. São Paulo: Max Limonad, 2003.

${ }^{83}$ SCAVONE, Lucila. Dar a vida e cuidar da vida: feminismo e ciências sociais. São Paulo: Editora UNESP, 2004.
} 
reprodutivos começou no final dos anos 1970, início dos anos 1980, no contexto da construção de uma sociedade democrática e igualitária após a ditadura militar. $\mathrm{Na}$ transição para o Estado democrático o movimento feminista brasileiro influenciou a criação do Programa de Assistência Integral à Saúde da Mulher (PAISM). O PAISM compreendia a integralidade corporal feminina em todas as fases da vida e primou pelo ineditismo e viés progressista. Representou o rompimento com o modelo assistencial materno-infantil realizado até então.

No período democrático a mobilização feminista utilizou a noção de direitos reprodutivos para o debate público sobre os temas de contracepção, aborto legalizado e assistência à saúde da mulher.

A Convenção Internacional sobre a Eliminação de Todas as Formas de Discriminação Contra Mulher de 1979 (CEDAW), prescreve em seu artigo 12, a eliminação da discriminação contra mulher na assistência à saúde, à gravidez, no parto e no pós-parto.

A Constituição Federal no seu artigo 226, parágrafo $7^{\circ}$, prevê que: "o planejamento familiar é livre decisão do casal, competindo ao Estado propiciar recursos (...)". Logo, o planejamento familiar engloba o direito à informação, à assistência especializada e acesso a recursos que fundamentem a decisão de ter ou não filhos. Esse dispositivo constitucional foi regulamentado pela Lei $n^{\circ}$ 9263/1996. A definição legal do planejamento familiar compreende o "conjunto de ações de regulação da fecundidade que garanta direitos iguais de constituição, limitação ou aumento da prole pela mulher, pelo homem ou pelo casal." É atribuição do Sistema Único de Saúde promover condições e recursos garantidores do livre exercício do direito ao planejamento familiar. O Estado deve oferecer métodos e técnicas de concepção e contracepção aceitos no campo da ciência e que não 
representem ameaça ou lesão à saúde e à vida das pessoas. Mulheres e homens devem ser avaliados e acompanhados clinicamente antes de qualquer prescrição de métodos, técnicas, benefícios, efeitos colaterais e graus de eficácia.

No plano nacional verificamos a Política Nacional de Atenção Integral à Saúde da Mulher - Princípios e Diretrizes (2003). E no ano seguinte, o Ministério da Saúde lançou a Política Nacional de Atenção Integral à Saúde da Mulher Princípios e Diretrizes.

A Secretaria de Políticas para as Mulheres da Presidência da República (SPM) possui o status de ministério, dispõe de maior estrutura burocrática composta por secretarias, secretarias executivas e cargos de direção e assessoramento superior. A SPM ocupa um assento no Conselho de Desenvolvimento Econômico e Social (CDES). O Conselho Nacional dos Direitos da Mulher (CNDM) é composto por 40 representantes distribuídos entre membros de organizações da sociedade civil, representantes do governo e representantes de notório conhecimento. $O$ Conselho tem poderes consultivo e deliberativo e as Conselheiras atuais exercem o mandato do período 2010-2013. Houve um aumento do aporte de recursos no período de 2008-2009 e além dos investimentos, a SPM incrementou a sua execução orçamentária em programas de promoção da cidadania das mulheres e enfrentamento da violência em prol da igualdade de gênero ${ }^{84}$.

A Secretaria de Políticas para as Mulheres da Presidência da República baseada nos resultados da $3^{\text {a }}$ Conferência Nacional de Políticas para as Mulheres 3a CNPM, ocorrida em 2011, iniciou o processo de formulação do Plano Nacional de Políticas para as Mulheres (PNPM-2012-2015). Campanhas para o enfrentamento da violência familiar e doméstica contra a mulher: "Compromisso e Atitude pela Lei

\footnotetext{
${ }^{84}$ A Secretaria de Estado dos Direitos da Mulher ( SEDIM) foi transformada em 2003 em Secretaria de Políticas para as Mulheres (SPM).
} 
Maria da Penha - A Lei é mais forte", a questão ambiental e o desenvolvimento sustentável na Rio +20 e na Cúpula dos Povos e os direitos das trabalhadoras domésticas (PEC das trabalhadoras domésticas" № 478/10) são apresentados como ações do Estado Brasileiro para a promoção dos direitos das mulheres e das políticas públicas para a igualdade de gênero. Para os fins da nossa pesquisa acreditamos que efetividade do direito à saúde da mulher negra precisa desse exame da trajetória dos direitos das mulheres brasileiras. A satisfação dos direitos das mulheres exige a construção da mulher como sujeito específico de direito e o reconhecimento de sua identidade e condição social.

"Enegrecendo o feminismo" é a expressão utilizada por Sueli Carneiro para denominar a História das mulheres negras no cerne do movimento feminista brasileiro. O movimento social das mulheres negras aparece nas lideranças religiosas do Candomblé e das Irmandades, passa pelas Rosas Negras (pertencentes à Frente Negra Brasileira), chegando à constituição de Organizações Não Governamentais ( ONGs) nos anos 1990 e 2000.

A fórmula clássica do movimento feminista de cor branca e ocidental é insuficiente na teoria e na prática política para a integração dos diferentes seres femininos em nossa sociedade multirracial e pluricultural. Conforme a lição de Sueli Carneiro, militante negra feminista, filósofa, fundadora do Geledés- Instituto da Mulher Negra:

Enegrecer o movimento feminista brasileiro tem significado, concretamente, demarcar e instituir na agenda do movimento de mulheres o peso que a questão racial tem na configuração, por exemplo, das políticas demográficas, na caracterização da questão da violência contra a mulher pela introdução do conceito de violência racial como aspecto determinante das formas de violência sofridas por metade da população feminina do país que não é branca; introduzir a discussão sobre as doenças étnicas/raciais ou as doenças com maior incidência sobre a população negra como questões fundamentais na formulação de políticas públicas na área de saúde; instituir a crítica aos mecanismos de seleção no mercado 
de trabalho como a "boa aparência", que mantém as desigualdades e os privilégios entre as mulheres brancas e negras. ${ }^{85}$

E neste trilhar de ideias, complementa:

A utopia que hoje perseguimos consiste em buscar um atalho entre uma negritude redutora da dimensão humana e a universalidade ocidental hegemônica que anula a diversidade. Ser negro sem ser somente negro, ser mulher sem ser somente mulher, ser mulher negra sem ser somente mulher negra. Alcançar a igualdade de direitos é converter-se em um ser humano pleno e cheio de possibilidades e oportunidades para além de sua condição de raça e de gênero ${ }^{86}$.

A tentativa de um feminismo negro é uma reação das mulheres negras à homogeneidade do movimento de mulheres. Segundo Jurema Werneck: "No feminismo original não havia diferenças palpáveis, de classe social ou de raça. Só existia a questão de gênero. ${ }^{, 87}$ Lélia González verifica que as questões levantadas por mulheres negras e brancas eram diferentes. As feministas brancas exigiam o ingresso no mercado de trabalho, mas a mão de obra das mulheres negras era explorada desde os tempos da escravização de pessoas. O feminismo tradicional tratava todas as mulheres como se fossem iguais. No entanto não podemos esquecer o papel desse movimento na conquista de espaços de poder para as mulheres negras. González afirma:

as representações sociais manipuladas pelo racismo cultural também estão internalizadas por um setor que, também discriminado, não se apercebe que, no seu próprio discurso, estão presentes mecanismos da ideologia do branqueamento e do mito da democracia racial. ${ }^{\circ 8}$

\footnotetext{
${ }^{85}$ CARNEIRO, Sueli. Enegrecer o feminismo: a situação da mulher negra na América Latina a partir de uma perspectiva de gênero. Este artigo foi apresentado no Seminário Internacional sobre Racismo, Xenofobia e Gênero, organizado por Lolapress em Durban, África do Sul, em 27 - 28 de agosto 2001.Publicado em espanhol na revista LOLA Press $n^{\circ} 16$, novembro 2001

${ }^{86}$ Idem, ibidem.

${ }^{87}$ LEMOS, Rosália de Oliveira. A face negra do feminismo: problemas e perspectivas. In: O livro da saúde das mulheres negras: nossos passos vem de longe/ (organização) Jurema Werneck, Maisa Mendonça, Evelyn C. White; ( tradução) Maisa Mendonça, Marilena Agostini e Maria Cecília MacDowell dos Santos.- Rio de Janeiro: Pallas: Criola, 2000.

${ }^{88}$ LEMOS, Rosália de Oliveira. Idem, p. 64.
} 
O processo de amadurecimento do feminismo negro trouxe consigo novas perguntas: igualdade de gênero e raça no direito à saúde, acesso à educação e ao mercado de trabalho, exercício da sexualidade etc. A pluralidade interna do feminismo negro pode ser observada no movimento negro, na luta feminista, nas demandas por moradia, nos cultos religiosos etc. Agora, as feministas negras devem agir para a consolidação de um mundo menos desigual. É este compromisso com os Direitos Humanos e a dignidade humana que Pedrina de Deus reforça ao recordar que :

A luta pela emancipação da mulher negra não tem por finalidade apenas formar mulheres seguras, capazes $e$ brilhantes, que visem com isto adquirir privilégios individuais. Essas conquistas são como veículos para gerar transformações na vida da população negra. ${ }^{89}$

${ }^{89}$ Idem, ibidem. p. 66-67. 


\title{
CAPÍTULO IV- A POLÍTICA PÚBLICA DE DIREITO À SAÚDE DA POPULAÇÃO NEGRA
}

A violenta captura, o tráfico transatlântico e regime escravista exigiram o planejamento e o manejo de ações mitigadoras de seus reflexos no campo do direito à saúde da população negra. Naquele período histórico, mulheres e homens negros recorriam apenas às práticas culturais e religiosas adaptadas ao continente americano e às suas condições precárias de vida.

No trabalho nas monoculturas de exportação, nas primeiras localidades urbanas ou nos quilombos, os negros e negras africanos e seus descendentes adaptaram seus costumes e práticas de tratamento e cura aos cenários locais, o que executavam calcados na memória ritualística, de seus símbolos e na luta por dignidade e liberdade. Desse modo, baseados nos rituais modificados e no uso de novos recursos da América, foram estabelecidos novos padrões de saúde.

\begin{abstract}
Novas folhas, novos animais, novas formas de sentir e traduzir os elementos da natureza e as reações do corpo e suas novas necessidades geraram novos rituais, novas religióes, novos remédios e formas de cuidado corporal e espiritual, unindo passado e presente..$^{90}$
\end{abstract}

Adaptações e inovações para o cuidado da saúde eram criadas e aprimoradas a partir dos cenários que a escravidão e a liberdade reconquistada apresentavam. Essas criações desempenharam papel fundamental na manutenção da integridade corpórea nos processos de empoderamento individual e coletivo para a conquista e garantia de direitos. $\mathrm{Na}$ atualidade, tais iniciativas são preservadas tanto por meio da medicina popular praticada em várias regiões do país, quanto das

\footnotetext{
${ }^{90}$ WERNECK, Jurema (Org.), Mulheres Negras: um olhar sobre as lutas sociais e as políticas públicas no Brasil. Publicação da Organização Não Governamental CRIOLA, p.7.
} 
práticas religiosas de tratamento e cura promovidas nas religiões de matrizes africanas ou mesmo nas orientações religiosas de origem cristã.

A História dos sistemas de atenção ao direito à saúde da população brasileira é identificada com as lutas empreendidas pela população marginalizada, onde sempre esteve a população negra, destituída de cuidado e participação. No exame dos diferentes modelos implementados pelo Estado brasileiro: Santas Casas de Misericórdia (a partir de 1582), Caixas de Aposentadorias e Pensões/ CAPs (1923), Institutos de Aposentadorias e Pensões/ IAPs (1926), Serviço de Assistência Médica Domiciliar/ SAMDU (1949), Instituto Nacional de Previdência Social/INPS (1966), Plano de Pronta Ação/ PPA (1968), Instituto Nacional de Assistência Médica da Previdência Social/ INAMPS (1974), Sistema Nacional de Saúde (1975), Programa de Interiorização de Ações de Saúde e Saneamento/ PIASS (1976), Programa de Desenvolvimento de Sistemas Unificados e Descentralizados de Saúde nos Estados/ SUDS (1987), verificamos a exclusão da população negra.

Negras e negros formavam o grupo minoritário de trabalhadoras/es formais e compunham a maior parcela dentre os habitantes das regiões mais carentes da atuação do Estado. A mudança constante de modelos de política pública de saúde, as tentativas diferentes de se estruturar a assistência à saúde da população, mesmo parcial, explicitam sinais da mobilização constante exercida pelos grupos excluídos.

O conceito de saúde da população negra, definido pelo movimento negro na década de 1980 e aprimorado pelo movimento de mulheres negras na década de 1990, está calcado na análise sistemática das desigualdades raciais do direito fundamental à saúde.

É a partir da compreensão da influência do racismo (estrutura de dominação que parte da crença de que há um grupo étnico/racial superior) sobre o processo de 
saúde/doença que ativistas, pesquisadores, profissionais de saúde, gestores negros (em sua maioria mulheres negras) e outros atores sociais, norteiam suas ações em busca da equidade, considerando o racismo e a discriminação racial como fatores determinantes das condições de exercício do direito à saúde ${ }^{91}$.

O direito à saúde da população negra deve ser construído e lapidado na compreensão e intervenção nos efeitos deletérios do racismo sobre a dignidade das pessoas, em particular de negras e negros, no confronto e superação das desigualdades materiais como requisito para a realização de uma sociedade efetivamente democrática, mais equânime e justa.

\subsection{Raça e Racismo}

As diferenças entre os povos é o ponto de partida para a criação da categoria "raça" como algo de determinação biológica e permitiu a divisão de toda a humanidade em grupos raciais, estabelecendo hierarquias entre eles e associando valores diferentes para cada um. A discriminação pode redundar em uma série de ações individuais, coletivas e políticas, tais como a segregação, a exclusão e a eliminação de indivíduos e grupos humanos inteiros.

Discursos cuidadosamente elaborados justificavam a perseguição do outro e a sua posterior eliminação. A construção teórica que explica a superioridade de uma "raça" em relação a outra é denominada "racismo".

Já foi cientificamente comprovado que inexistem "raças biológicas". Também já se demonstrou a desvinculação entre biologia ou genética e a prática de injustiças ou desigualdades. Os diversos tons de pele ou outras características atribuídas à

\footnotetext{
${ }^{91}$ Conquistando Direitos- a Experiência do Projeto Piloto Direito à Saúde da Mulher Negra. Coordenado por Bruna Angotti e Nathalie Nunes. São Paulo: Conectas Direitos Humanos, 2010.p. 26-27
} 
"raça" não são suficientes para fundamentar as condições de dominação e subordinação a que os grupos de mulheres e homens negros estão submetidos no Brasil e em outras regiões do mundo. "Raça" e sua definição são construções sociais e revelam a existência e a prática de um sistema sofisticado de hierarquização social que lança mão das características biológicas para estabelecer desigualdades entre grupos humanos.

Em nosso país a inferioridade das mulheres e homens negros foi legitimada socialmente e os descendentes dos diferentes povos africanos submetidos à escravização foram relegados ao estrato inferior das hierarquias social, econômica, cultural etc.

Como elucida Eunice Prudente:

A violação à dignidade com as violências suportadas e as revoltas pela liberdade marcaram os afro-descendentes. $\mathrm{Na}$ mesma proporção a classe proprietária escravista violadora de direitos também permanecerá delineada pelo próprio atraso e pela incapacidade de forjar uma sociedade firmada na liberdade, igualdade e na responsabilidade social, o que implicaria, no mínimo, numa melhor distribuição das rendas. ${ }^{92}$

É o conceito social de raça que alimenta o sistema racista naturalizado, estabelecido e propagado. Não é fruto da simples escolha, vontade ou opinião das pessoas. É um fenômeno ideológico que atinge a todas e todos, negros, negras, brancos, amarelos, indígenas, sem qualquer distinção. O racismo brasileiro também é construção histórica e serve aos interesses dos grupos dominantes. Afeta a dignidade, a qualidade de vida e a saúde da população negra em todas as fases do ciclo vital, de todos os extratos sociais, nos centros urbanos e na área rural. Reafirmado no cotidiano, na linguagem, nos meios de comunicação etc. Enfrentar o racismo envolve a interação de vários atores políticos e suas intervenções no

\footnotetext{
${ }^{92}$ PRUDENTE, Eunice Aparecida de Jesus. Educação em Direitos- Um caminho para a Igualdade Racial. p. 7
} 
funcionamento das instituições públicas, nas organizações sociais e também nas relações pessoais.

\subsection{Racismo Institucional}

O racismo institucional, também chamado de racismo sistêmico ou estrutural, é um conceito criado pelo ativismo negro para assinalar a incapacidade coletiva na prestação de um serviço adequado às pessoas em razão de sua cor/etnia, cultura ou origem. O racismo penetra a organização do Estado, o sistema educacional, o competitivo mercado de trabalho e influencia o direito à saúde da população negra. O racismo institucional na saúde é nocivo, uma vez que suas práticas são veladas e ocultas, fenômeno raramente explícito. Resulta na reprodução dos interesses, ações e mecanismos de exclusão dos grupos dominados e para o controle, manutenção e expansão de privilégios dos grupos dominantes ${ }^{93}$.

\subsection{Interseccionalidade}

O exame das desigualdades apresentadas na representação política, no plano educacional e no exercício do direito à saúde deve articular todos esses elementos, a análise isolada não fornece subsídios para perceber a violação dos direitos humanos das mulheres negras de modo eficaz.

\footnotetext{
${ }^{93}$ Segundo Fernanda Lopes e Rachel Quintiliano, estudiosas que trabalham com o tema da desigualdade racial em saúde, racismo institucional define-se como: "Normas, práticas e comportamentos discriminatórios adotados no cotidiano de trabalho, resultantes da ignorância, da falta de atenção, do preconceito ou da incorporação e da naturalização de estereótipos racistas. Em qualquer caso, o racismo institucional sempre impõe a pessoas de grupos raciais ou étnicos discriminados situação de desvantagem no acesso a benefícios gerados pelo Estado, por instituições e organizações públicas e privadas.” In: Conquistando Direitos- a Experiência do Projeto Piloto Direito à Saúde da Mulher Negra.p.26
} 
A interseccionalidade ${ }^{94}$ é conceito elaborado no final da década de 1980 pela professora de direito constitucional Kimberlé W. Crenshaw da Universidade de Columbia (Nova lorque) e Universidade da Califórnia (Los Angeles). Graças à aplicação da interseccionalidade ${ }^{95}$ é descabido isolar qualquer um dos fatores atuantes na vida de indivíduos e grupos marginalizados socialmente, seja raça/cor/etnia, gênero, classe social, condições de saúde, escolaridade, posto de trabalho para a humana e justa percepção da complexidade e interação entre eles. Para a efetivação dos direitos humanos das mulheres negras, as afirmações de Crenshaw se aplicam perfeitamente:

\begin{abstract}
A discriminação interseccional é particularmente difícil de ser identificada em contextos onde forças econômicas, culturais e sociais silenciosamente moldam o pano de fundo, de forma a colocar as mulheres em uma posição onde acabam sendo afetadas por outros sistemas de subordinação. Por ser tão comum, a ponto de parecer um fato da vida, natural ou pelo menos imutável, esse pano de fundo estrutural é, muitas vezes, invisível. O efeito disso é que somente o aspecto mais imediato da discriminação é percebido, enquanto que a estrutura que coloca as mulheres na posição de "receber" tal subordinação permanece obscurecida. Como resultado, a discriminação em questão poderia ser vista simplesmente como sexista (se existir uma estrutura racial como pano de fundo) ou racista (se existir uma estrutura de gênero como pano de fundo). Para apreender a discriminação como um problema interseccional, as dimensões raciais ou de gênero, que são parte da estrutura, teriam de ser colocadas em primeiro plano, como fatores que contribuem para a produção da subordinação.
\end{abstract}

Nossa apropriação do conceito de interseccionalidade permite a visibilidade das diferenças (desigualdades e privilégios) no interior da nossa população brasileira. Dessa forma, subsidia a formulação de políticas públicas orientadas pelas vivências e necessidades de cada grupo social. A adequação das políticas públicas permite também maior efetividade aos direitos fundamentais universais, inalienáveis e indivisíveis.

\footnotetext{
${ }^{94}$ Kimberly W. Crenshaw é uma das líderes da "Critical Race Theory", teoria que ressalta a realidade do conceito social de raça e promove a luta contra as diversas formas de subordinação, especialmente as discriminações de raça/etnia e gênero.

${ }^{95}$ CRENSHAW, Kimberlé. Documento para o encontro de especialistas em aspectos de discriminação racial relativos ao gênero. Revista Estudos Feministas. Vol.10. nº1. Florianópolis. Jan. 2002.
} 


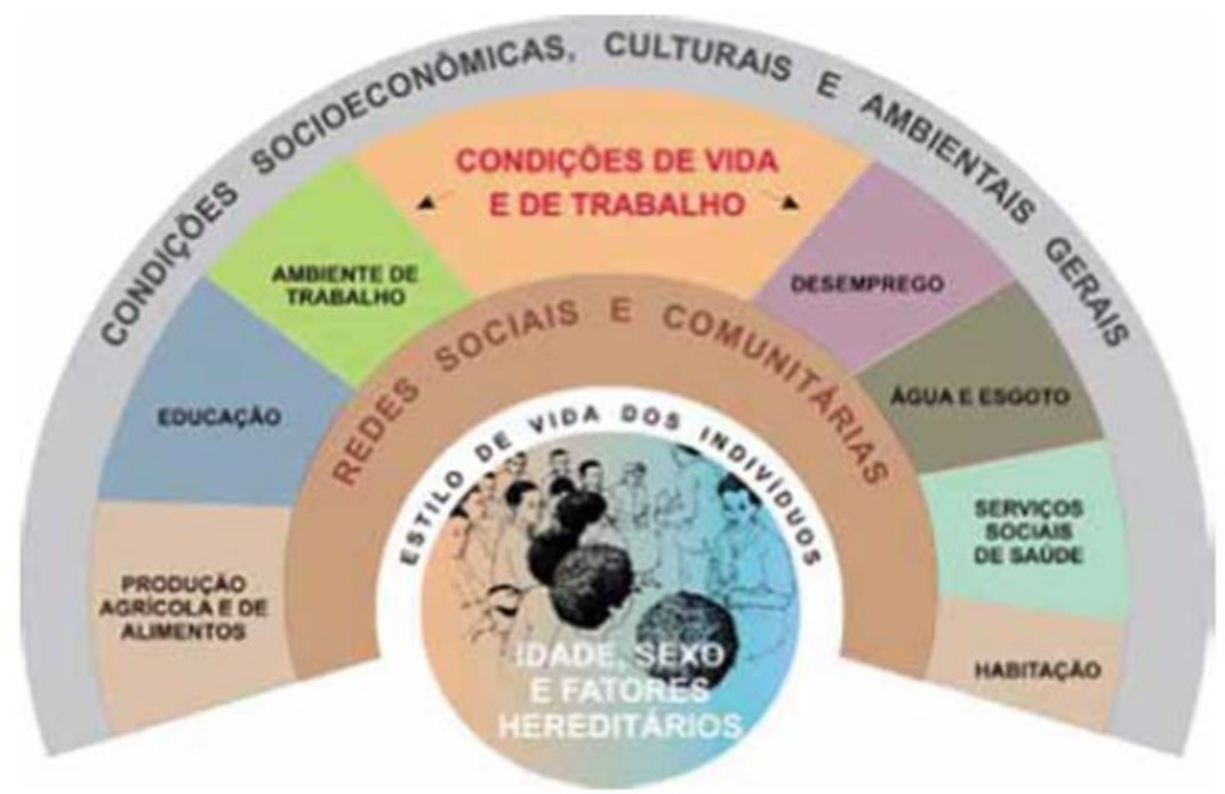

Figura 2: Modelo de determinação social da saúde por Dahlgren e Whitehead

Fonte: Saúde da mulher negra: guia para a defesa dos direitos das mulheres negras / Articulação de Organizações de Mulheres Negras Brasileiras. - Porto Alegre, 2012.

Os conceitos de direitos humanos, igualdade de gênero e igualdade racial no campo da saúde da população negra dependeu e ainda depende da participação das organizações de mulheres negras, do movimento negro, da luta feminista de modo a arregimentar forças e novos atores para a diminuição das iniquidades.

Apresentamos a seguir algumas sugestões de estratégias para a identificação, intervenção e enfrentamento do racismo na saúde da população negra:

- o incentivo para a realização de pesquisas acadêmicas sobre o direito à saúde da população negra em nível nacional e no plano local, com a apresentação de propostas do que se almeja e a descrição das etapas para o alcance da política pública teorizada; 
- a participação de diversos atores políticos nos debates acadêmico, comunitário e político dos problemas prioritários às condições de saúde da população negra;

- a seleção dos problemas para a agenda pública, a tomada de decisões e a atribuição de competências para a execução da política pública de saúde conforme as etapas do ciclo de vida, o gênero, a categoria profissional etc.;

- a construção de indicadores quantitativos e qualitativos para o monitoramento das ações, programas e políticas. As etapas de monitoramento e avaliação das políticas públicas permitem que os gestores, profissionais da saúde e a sociedade como um todo, possam verificar se as ações e serviços públicos foram sinônimo de justiça e adequação às necessidades de todos e todas, se os resultados obtidos foram satisfatórios e equitativos e, em última instância, se houve ou não alterações no quadro de desrespeito aos direitos humanos.

Sob a égide perversa do racismo, outras formas de inferiorização social têm as suas ações e efeitos intensificados. Na intersecção de vários fatores de discriminação e marginalização, os impactos negativos podem ser ainda mais nocivos à saúde de negras e negros. Logo, é suma importância que os profissionais do direito, os ativistas de direitos humanos, os profissionais de saúde e os agentes políticos tomadores de decisão em matéria de políticas públicas, estejam bem formados e habilitados para que as ações e os serviços de saúde pública tenham qualidade técnica, equidade e a inspiração do valor ético da dignidade humana. Sob o aspecto da ética ${ }^{96}$ na execução da política pública de saúde da população negra destacamos a importância do compromisso dos gestores das organizações de

\footnotetext{
96 Sustentamos neste trabalho a dignidade humana como fundamento ético dos direitos fundamentais, logo, podemos concluir a estreita relação entre ética da saúde pública e direito à saúde.
} 
saúde ${ }^{97}$. A Ética da Saúde ${ }^{98}$, segundo o apurado entendimento de Dalmo de Abreu

Dallari da obra homônima de Giovanni Berlinguer, consiste em uma série de princípios que possuem um pressuposto comum (a dignidade da pessoa humana) na formulação e execução de ações de prevenção, promoção e tratamento em saúde. A obediência à Ética da Saúde implica em reflexões permanentes sobre a prioridade da dignidade humana em relação dos demais interesses políticos, econômicos etc.

Em nosso sentir e diante dos temas apresentados até aqui o maior dos desafios para a materialização do direito fundamental à saúde da população mulher negra brasileira (e por conseguinte da mulher negra do município de São Paulo) é assegurar o Sistema Único de Saúde (SUS) como Política Pública. No mesmo sentido, reproduzimos as recomendações de Jurema Werneck em artigo publicado no Jornal Irohin ${ }^{99}$ :

A defesa do SUS se coloca então como fundamental neste momento. Pois quando falamos de saúde da população nega em seus diferentes aspectos, temos que ter no horizonte a constatação de que sem o SUS muito pouco poderá ser feito. $E$ isto não é uma questão de técnicos, é sim política. As organizações negras e sua mobilização devem explicitar cada vez mais suas pautas e ações de defesa das políticas públicas e do SUS como questão de princípio e de sobrevivência. É preciso pressionar, denunciar, não permitir recuos nas políticas municipais, estaduais e federais. É preciso ter em mente o que já foi feito e já foi dito: "Como alguém que tenha vivido entre camponeses ou favelados sabe muito bem, a saúde do povo é influenciada muito mais por políticos, grupos de poder e pela distribuição da terra e da riqueza do que é pela prevenção e tratamento de doenças.

\footnotetext{
${ }^{97}$ Para maior aprofundamento sobre a influência da estrutura social de poder sobre as decisões dos gestores dos serviços de saúde, ver JERICÓ, Marli de Carvalho, PERES, Aida Maris e KURCGANT, Paulina. Estrutura Organizacional do serviço de enfermagem: reflexões sobre a influência do poder $e$ da cultura organizacional.In: Revista da Escola de Enfermagem da Universidade de São Paulo, 2008; 42(3): 569-77.

98 DALLARI, Dalmo de Abreu. Ética Sanitária. In: Curso de Especialização a Distância em Direito Sanitário para membros do Ministério Público e da Magistratura Federal.

99 LOPES, Fernanda, WERNECK, Jurema. Saúde da população negra. Da conceituação às políticas públicas de direito. In: Mulheres Negras :um Olhar sobre as Lutas Sociais e as Políticas Públicas no Brasil. Organizadora Jurema Werneck. Rio de Janeiro: Criola, 2012.
} 


\subsection{Política Nacional de Saúde Integral da População Negra - PNSIPN}

A política pública de direito à saúde da população negra recebe o nome de "Política Nacional de Saúde Integral da População Negra - PNSIPN". Sua criação e aprovação são resultados da atuação do Movimento de Mulheres Negras e do Movimento Negro na dinâmica das políticas públicas com recorte multicultural, dois temas já mencionados em nosso trabalho. A participação de um ator visível na política pública, a AMNB (Articulação de Organizações de Mulheres Negras) no órgão tomador de decisões no plano federal, qual seja, o Conselho Nacional de Saúde, constituiu janela de oportunidade para a mudança da agenda na saúde pública e a aprovação da PNSIPN no ano de 2006. A imagem pública dessa política passa pelo reconhecimento do racismo como determinante da saúde e a necessidade de sua erradicação. A PNSIPN foi incorporada ao Estatuto da Igualdade Racial (Lei no 12.288/2010) em 2011.

\subsection{O Estatuto da Igualdade Racial e a Saúde}

Em 20 de julho de 2010 entrou em vigor a Lei Federal nำ12.288, o Estatuto da Igualdade Racial, após muitos debates legislativos. Referido diploma legal contém uma série de direitos, deveres do Estado, objetivos e metas para brasileiras e brasileiros sem distinção de qualquer natureza.

O Estatuto da Igualdade Racial não é fruto de geração espontânea.

Ele não surgiu de um vácuo sociopolítico, ou seja, sem história de luta dos movimentos negros e/ou de seus aliados dentro e fora do parlamento brasileiro, por meio de políticas de promoção da igualdade racial, menos ainda de um vácuo de propostas relativas aos marcos normativos que dizem respeito à questão racial brasileira. A proposta formal do Estatuto foi, em realidade, um agregado de várias outras proposições que 
objetivavam a igualdade racial por meio da legislação. Proposições apresentadas também e anteriormente por vários outros parlamentares negros e não negros.

Mas a formalização de uma proposta de Estatuto da Igualdade Racial por parte do deputado federal e depois senador Paulo Paim (PT/RS) levou 10 anos para ser definitivamente aprovada no Congresso Nacional. A sua primeira apresentação formal no parlamento brasileiro ocorreu em 7 de junho de 2000. Já a sua aprovação se deu em 16 de junho de 2010. Por fim, sua sanção pelo presidente da República e, consequentemente, sua transformação na Lei n. ${ }^{\circ} 12.288$ ocorreram em 20 de julho de $2010^{100}$.

O Estatuto da Igualdade Racial apresenta também um sistema de garantias para a fruição de direitos: cabe ao Estado brasileiro um papel proativo na questão da igualdade racial. A repressão da discriminação racial na esfera penal ${ }^{101}$ continua relevante, mas os mecanismos repressivos apresentam ao menos duas limitações: a) postura passiva dos Poderes Públicos, que interferem após a violência do ato de discriminação e b) o foco nos efeitos mas não nos fatores determinantes da desigualdade racial, óbvia violação de direitos humanos.

A promoção da igualdade racial do Estatuto significa ações preventivas e positivas para que a igualdade jurídica se faça presente nas oportunidades e no tratamento de negras e negros nos bancos escolares, no mercado de trabalho e nos bens e serviços de saúde pública.

A política pública de igualdade racial presente no Estatuto prevê a alocação de recursos da União, Estados, Distrito Federal e Municípios para os programas e ações de promoção dos direitos fundamentais da população negra. Os gestores na etapa de formulação e planejamento das políticas de qualquer área (saúde, educação, mercado de trabalho etc.) tem a incumbência de destinar parte dos

\footnotetext{
${ }^{100}$ SANTOS, Sales Augusto dos; SANTOS, João Vitor Moreno dos; e BERTÚLIO, Dora Lúcia. O processo de aprovação do Estatuto da Igualdade Racial, Lei n. ${ }^{\circ}$ 12.288, de 20 de julho de 2010. Brasília: INESC, 2011.

${ }^{101}$ Eunice Aparecida de Jesus Prudente em sua Dissertação de Mestrado: Preconceito racial e igualdade jurídica no Brasil, defendida na Faculdade de Direito da Universidade de São Paulo em 1980 sustentou brilhantemente a reforma da legislação penal brasileira no sentido de caracterizar e punir a discriminação racial como crime contra a pessoa. Tal proposta, a despeito de positiva para a dignidade humana de parcela majoritária da população brasileira, até o presente não foi acolhida em nosso ordenamento jurídico.
} 
recursos para a execução de programas e ações de promoção da igualdade racial, sob pena da política pública ficar reduzida ao papel e à tinta de declarações e leis.

$\mathrm{Na}$ fase de monitoramento da política pública de igualdade racial, as organizações sociais devem acompanhar as discussões sobre planos plurianuais, leis de diretrizes orçamentárias e leis orçamentárias anuais para que a peça orçamentária contemple a dignidade humana, fundamento do nosso Estado Democrático de Direito. Sem a previsão de recursos financeiros, materiais e humanos dirigidos à política pública, os direitos fundamentais ficam reduzidos às boas intenções e o segmento social interessado dependerá da "boa vontade" dos agentes políticos.

Derradeiramente, na avaliação da política pública, as contribuições coletivas e individuais na ciência e divulgação das metas e objetivos do Estatuto da Igualdade Racial permitirão a inclusão social da população negra, o acesso adequado à saúde e à educação, a valorização da cultura e do lazer, a liberdade de crença, o direito à terra e à moradia, oportunidades de trabalho digno e participação igualitária nos meios de comunicação social.

O Estatuto da Igualdade Racial trata da saúde (artigos 11 a 17) ao reconhecer que o exercício pleno desse direito fundamental está subordinado a fatores condicionantes como a raça/cor/etnia, o meio ambiente, os hábitos alimentares, o segmento profissional e a maior ou menor incidência de determinadas enfermidades. Há doenças que atingem mais diretamente a população negra. São as denominadas doenças prevalentes, que afetam frequentemente determinado grupo étnico-racial. Pesquisas demonstram as patologias mais comuns na população negra brasileira, embora não exclusivas desse grupo. As doenças prevalentes na população negra são a hipertensão 
arterial, a anemia falciforme, a doença hipertensiva específica da gravidez e o diabetes mellitus.

O Estatuto determina para a garantia do tratamento igualitário e a promoção da saúde integral da população negra as seguintes medidas: o financiamento de pesquisas e produção científica em saúde; a coleta de dados para o controle das doenças prevalentes; a formação profissional de saúde com enfoque étnico-racial e a presença de lideranças do movimento negro nos espaços de participação e controle social do Sistema Único de Saúde (SUS).

Ao lado das doenças prevalentes na população negra, há uma lista de patologias que acometem apenas as mulheres negras, tais como câncer de colo de útero, câncer de mama, doença inflamatória pélvica etc. A detecção precoce dessas doenças e a realização de exames/tratamentos adequados aumentam as chances de cura. A gravidez também expõe a mulher negra à riscos para a saúde quando há negação do acesso aos cuidados específicos durante e após a gestação. A prevenção da mortalidade materna passa pelo acesso à igualdade e justiça nos programas de planejamento familiar e serviços de atenção à saúde no pré-natal, parto e puerpério.

À guisa de exemplo,apresentamos alguns dados de mortalidade materna no Brasil e a desigualdade racial que atinge as mulheres negras na política pública de saúde: 
Figura 3: Óbitos maternos de mulheres em idade fértil, segundo raça/cor, 2010.

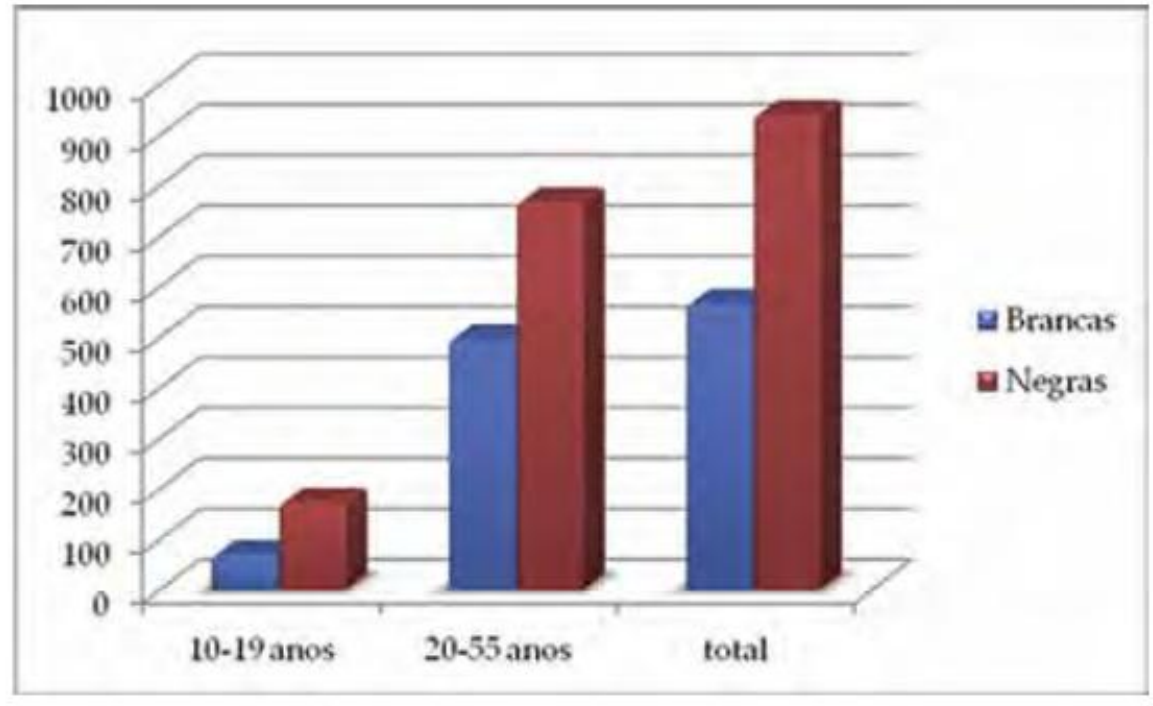

Fonte: SVS/ MS, 2012

Figura 4: Mortes maternas na faixa etária de 10 a 19 anos por raça/cor segundo causas.Brasil, 2010

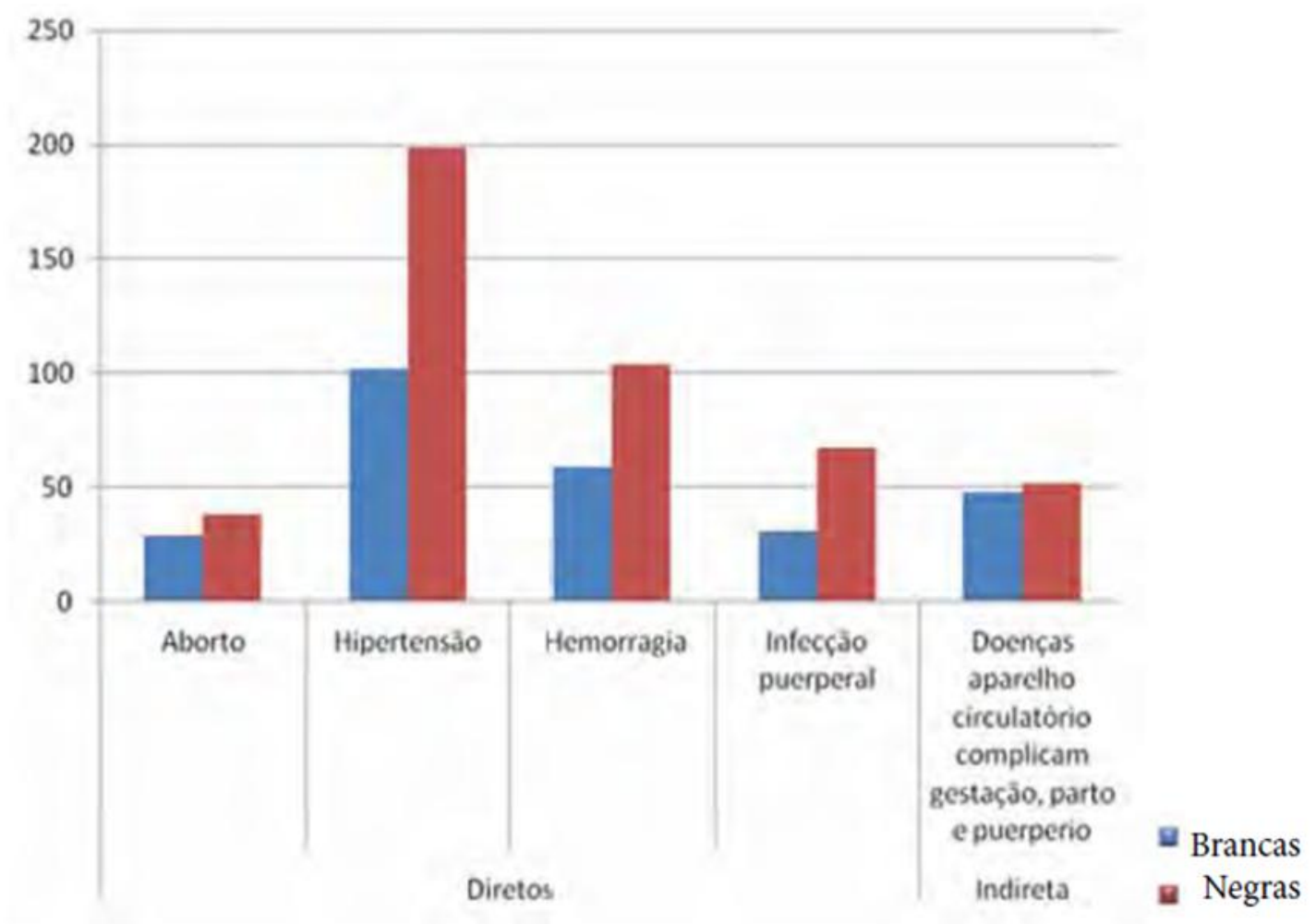

Fonte: SVS/MS,2012 
Os gráficos demonstram que as mulheres negras faleceram mais por causas relacionadas à gravidez do que as mulheres brancas. A hipertensão arterial e as hemorragias, por exemplo, poderiam ter sido evitadas no caso de mulheres e jovens negras se os objetivos e metas da política nacional de atenção à saúde da população negra tivessem sido efetivados de modo expressivo.

\subsection{O Programa Estadual de Políticas Afirmativas do Estado de São}

\section{Paulo}

O Estatuto da Igualdade Racial no tema do direito à saúde apresenta o dever do Poder Público nas três esferas de governo: União, Estados e Municípios. A Secretaria de Estado da Saúde de São Paulo (SES-SP) é o locus de formulação, planejamento e execução da Política Pública Nacional de Igualdade Racial denominada Programa Estadual de Políticas Afirmativas para Afrodescendentes harmonizada com a Política Nacional de Saúde da População Negra. A Secretaria de Estado da Saúde de São Paulo - SES-SP - pela formulação da Política Estadual de Saúde e de suas diretrizes, pautada pelos princípios do Sistema Único de Saúde - SUS, promovendo a saúde, priorizando as ações preventivas e democratizando as informações para a avaliação e o controle social.

A SES-SP possui 17 Departamentos Regionais de Saúde (DRS) distribuídos pelo Estado três fundações: a do Remédio Popular (FURP), que tem como finalidades a pesquisa, o desenvolvimento, fabricação e distribuição de medicamentos; a Oncocentro de São Paulo (FOSP), que apresenta subsídios para a política pública de prevenção e combate ao câncer e a Pró-Sangue Hemocentro de 
São Paulo, centro de pesquisas internacionais e do controle e fiscalização de hemocomponentes e serviços hemoterápicos.

O controle da ocorrência de doenças, seu aumento e propagação, desenvolvidas principalmente pela Vigilância Epidemiológica, o controle da qualidade de medicamentos, exames, alimentos, higiene e adequação de instalações que atendem ao público, área de atuação da Vigilância Sanitária e o controle de endemias na Superintendência de Controle de Endemias - SUCEN são outras atribuições da Secretaria Estadual de Saúde de São Paulo.

O controle social e a participação da comunidade na definição de prioridades e necessidades, no acompanhamento e avaliação das ações executadas são garantidos a partir das instâncias Conselho Estadual de Saúde (CES) e Comissão Intergestores Bipartite (CIB).

A Resolução 173, de 08 de setembro de 2010 constituiu o Comitê Técnico de Saúde da População Negra do Estado de São Paulo sob as diretrizes nacionais de prevenção e combate da discriminação racial, étnica e sexual em ações serviços de saúde. O diploma cita explicitamente que a população negra precisa de tratamento diferenciado em prol da equidade e é titular de problemas específicos de saúde, que exigem ações particulares do Sistema Único de Saúde (SUS) no território paulista. O Comitê é formado por representantes de todos os departamentos da Secretaria de Estado da Saúde, de associações da sociedade civil organizada, das universidades paulistas de organizações não governamentais do movimento negro.

As principais propostas do Comitê Técnico estão impressas no Objetivo 14 da Política Estadual ${ }^{102}$ : aplicar estratégias para facilitar a implantação da Política de Atenção Integral à Saúde da População Negra. Por sua vez, as metas e resultados

\footnotetext{
${ }^{102} \mathrm{http}: / /$ redesaudedapopulacaonegra.org/wpcontent/uploads/2010/04/Dco_base_PopulacaoNegra.pdf
} 
variam da qualificação dos recursos humanos de serviços de saúde, passam pela realização de seminários temáticos até o aumento da produção científica sobre o tema da saúde da população negra.

Luis Eduardo Batista e Rosana Batista Monteiro defendem uma política pública de caráter universal na atenção à saúde sem olvidar as diferenças entre os indivíduos, notadamente os pertencentes à população negra no artigo "Política de Saúde da População Negra no Estado de São Paulo: focalizando para promover a universalização do direito à saúde?"103 Nessa publicação, os autores defendem que as ações e programas desenvolvidos no Estado de São Paulo (um dos primeiros Estados da federação a executar políticas de garantia da saúde da população negra) são de natureza universalista em obediência aos princípios do SUS e, portanto, mais próximas do sucesso do que as políticas públicas focalizadas, associadas ao assistencialismo e a mecanismos compensatórios.

No caso da saúde da população negra, São Paulo foi um dos primeiros estados a implantar políticas de atenção à saúde para garantir a atenção integral à saúde da população negra (desde 2003); esse processo se deu frente à necessidade de atender às populações vulneráveis e promover a justiça e a equidade. Para isso, as SES-SP desenvolveu: 1) ações de sensibilização e 2) elaborou projetos e propostas de políticas dentro dos demarcadores e instrumentos de gestão do SUS.

Dentre as ações de sensibilização desenvolvidas, destaca-se a produção do conhecimento científico sobre a temática; a extensão às comunidades remanescentes de quilombolas, a atenção, por equipes do QUALIS/PSF; a realização de Seminários Estaduais e Regionais de Saúde da População Negra e a Criação do Comitê Técnico de Saúde da População Negra. ${ }^{104}$

\footnotetext{
${ }^{103}$ BIS, Bol. Inst. Saúde (Impr.) v.12 n.2 São Paulo ago. 2010.

${ }^{104}$ Idem, ibidem.
} 


\subsection{A política pública de promoção da igualdade racial no município de}

\section{São Paulo}

\subsubsection{Conselho Municipal do Negro}

O Conselho Municipal do Negro na capital do Estado de São Paulo é fruto da janela de oportunidade para a mudança da agenda da política pública proporcionada pela redemocratização na década de 1980 ao Movimento Negro Brasileiro. O Decreto $n^{\circ} 24.986$ de 20 de novembro de 1987 criou o Conselho Municipal do Negro, um dos primeiros espaços institucionais para a implementação de políticas públicas de promoção da igualdade racial na cidade de São Paulo.

A CEN - Coordenadoria Especial do Negro foi objeto de norma municipal após a eleição da Prefeita Luiza Erundina do Partido dos Trabalhadores (PT) na forma do Decreto n 28.074/1989. Em 22 de dezembro de 1992, a mesma Chefe do Poder Executivo Municipal sancionou a Lei $n^{0}$ 11.321, criadora da Coordenadoria dos Assuntos da População Negra/CONE.

A Coordenadoria dos Assuntos da População Negra - CONE - é um órgão da administração municipal direta, vinculado inicialmente à Secretaria de Governo. Pouco depois foi ligada à Assessoria de Cidadania e Direitos Humanos da Secretaria do Governo Municipal do Gabinete do Prefeito em 20 anos de políticas públicas etnicorraciais no município de São Paulo. Atualmente, a CONE está sob à égide da Secretaria Municipal de Participação e Parceria (SMPP). Apresenta sua missão, finalidade e competências em seus documentos normativos, dentre eles a formulação, coordenação e acompanhamento de políticas públicas focadas na população negra, visando a prevenção e o combate à discriminação racial e a 
defesa dos direitos, bem como a promoção e o apoio à integração cultural, econômica e política desta população ${ }^{105}$.

\subsubsection{Conselho de Gestão do CONE}

O Conselho de Gestão do CONE foi constituído em 07 de novembro de 2007, é parte integrante da estrutura política da Coordenadoria dos Assuntos da População Negra e é constituído por representantes da Sociedade Civil e do Poder Público, que são eleitos para um mandato de dois anos, com direito a uma recondução. Os objetivos do Conselho de Gestão ${ }^{106}$ abrangem os mecanismos de participação e controle social da política pública de igualdade racial no município, a garantia da execução das políticas da Coordenadoria de Assuntos da População Negra e a apresentação de diretrizes garantidoras dos direitos da população negra. A Coordenadoria de Assuntos da População Negra mantém um Centro de Referência em Direitos Humanos na Prevenção e Combate ao Racismo (Decreto no 47.897/2006) que, sob o ponto de vista da política nacional de igualdade racial atua em duas frentes: a proativa ou preventiva ao fomentar debates, fóruns e oficinas com o objetivo de divulgar e sensibilizar a população do município de São Paulo quanto a importância da defesa dos diretos humanos e a todas as formas de discriminação racial, a segunda vertente é a repressiva, o combate ao racismo no acompanhamento, atendimento e encaminhamento jurídico e psicossocial para as vítimas de racismo. Na área da educação, a Coordenadoria Especial dos Assuntos da População Negra apresentou o Programa de Formação Pedagógica de Combate ao Racismo, programa de política pública desenvolvido no interior da Secretaria

\footnotetext{
105 Coordenadoria dos Assuntos da População Negra 20 anos de contribuição para as Políticas Públicas Etnicorraciais no município de São Paulo. Organização: Maria Aparecida de Laia. Prefeitura de São Paulo. Coordenadoria dos Assuntos da População Negra- CONE. Imprensa Oficial do Estado de São Paulo. 2012.

${ }^{106} \mathrm{http} / / /$ telecentros.sp.gov.br/img/arquivos/relatorio_conselho_cone_0910.pdf
} 
Municipal de Educação. Ao município cabe produzir materiais didático-escolares, subsidiar a formação inicial e continuada do corpo docente e orientar o sistema de ensino local na implementação de políticas educacionais igualitárias. Há a previsão do apoio a ações educacionais empreendidas por organizações da sociedade civil, assim como a participação de pesquisadores e representantes do Movimento Negro nas instâncias de participação e controle social da educação.

O Estatuto da Igualdade Racial protege as manifestações da cultura afrobrasileira como um todo, e nesse sentido, a CONE na área cultural prevê a execução de ações de proteção e valorização do patrimônio histórico material e imaterial (exemplo: estruturação do Acervo do Viver Afro-Brasileiro - Jabaquara); resgate dos sítios e figuras históricas da comunidade negra no município e inserção da contribuição histórica e artística da população negra na Secretaria Municipal de Cultura.

No direito à igualdade racial no mercado de trabalho e produção de renda, a CONE adotou as seguintes medidas no ano de 2012 a realização do Seminário: "Definição das Áreas de Atuação do Fórum Intersecretarial de Desenvolvimento Econômico para Afrodescendentes do Município de São Paulo" e a publicação: "Promoção de Igualdade de Gênero e Raça no Trabalho". 


\subsection{Política de Saúde Pública da população negra no município de São}

\section{Paulo}

A política pública de saúde pública para a população negra no município de São Paulo é uma parceria entre o CONE e a Secretaria Municipal de Saúde (SMS), com a colaboração da Associação de Anemia Falciforme do Estado de São Paulo. A primeira ação do CONE no direito à saúde foi a inclusão do quesito cor nos serviços e equipamentos municipais para a formulação e desenvolvimento de políticas públicas específicas.

No âmbito da Secretaria Municipal de Saúde encontramos o corpo normativo da promoção do direito à saúde da população negra. A Portaria nº 696/90 determina a introdução do quesito cor no Sistema de Informação em 1989. A Portaria no 545/04 regulamenta a coleta do quesito cor e o preenchimento do campo denominado raça/cor nos Sistemas de Informação em Saúde no município de São Paulo. Em matéria de resoluções das Conferências Municipais de Saúde da População Negra, destacamos a 1a Conferência Municipal de Saúde da População Negra: "Controle Social e Inclusão Étnico-Racial no SUS" (Resolução 13/03 - CMS de 26/06/2003). Ocorrida de 14 a 16 de maio de 2003 foi o primeiro encontro dessa natureza no cenário nacional. A $2^{\text {a }}$ Conferência Municipal de Saúde da População Negra foi realizada de 8 a 10 de novembro de 2006. A Portaria $n^{\circ}$ 907/06 que institui o Comitê Assessor de Política e Consensos Técnicos de Saúde da População Negra e outras minorias étnicas e raciais. O exame da Conferência Nacional de Promoção da Igualdade Racial (2009) ${ }^{107}$ apresenta a Política Nacional de Saúde da População Negra. Seu compromisso é reduzir os diferentes graus de

107 Os subsídios para a Conferência Nacional de Promoção da Igualdade Racial estão disponíveis na Internet: https://www.presidencia.gov.br/seppir 
vulnerabilidade a que mulheres e homens negros estão suscetíveis em decorrência da desigualdade social e da discriminação racial. A Área Técnica de Saúde da População Negra foi criada em setembro de 2003, com o objetivo de formular ações que promovam, no âmbito do Sistema Único de Saúde (SUS) Municipal, a redução das iniquidades em saúde relacionadas à questão racial, reconhecendo as especificidades deste segmento da população. A Área Técnica Saúde da População Negra integra a Coordenação da Atenção Básica da Secretaria Municipal de Saúde desde 2008 facilitando a atuação transversal com as demais secretarias, compartilhando diretrizes, bem como recursos materiais, humanos e financeiros, pactuados no Plano Municipal de Saúde com outras áreas técnica. A área desenvolve ações de sensibilização e capacitação dos profissionais de saúde, visando a mudança de práticas na Secretaria Municipal de Saúde (SMS), no sentido de promover ações que atendam as especificidades da saúde da população negra e atuar no combate ao racismo institucional.

Nas ações preventivas há a previsão de programas de redução da mortalidade por anemia falciforme em neonatais e crianças abaixo de um ano. Este serviço já está em atividade na Maternidade Nova Cachoeirinha e em outras unidades básicas de saúde (UBS). O diagnóstico de anemia falciforme será realizado através do exame de sangue conhecido como teste do "pezinho". O programa está em fase de ampliação nas UBS que correspondem atualmente ao extremo da Zona Leste e posteriormente será levada aos bairros da Zona Sul. O serviço de detecção e informação sobre a enfermidade será expandido em todas as unidades de saúde municipal, inclusive com atendimento de indivíduos adultos com a coleta de sangue da ponta do dedo. As ações programáticas da área técnica são apresentadas como focalizadas no diagnóstico dos doentes, incluindo as gestantes, 
na organização da rede de assistência pactuada com da Atenção Básica; o planejamento das ações educativas e na elaboração de material informativo aos profissionais de saúde e à população; o dever de consolidar a articulação entre as três esferas governamentais; a constituição e organização do Grupo de Trabalho GT de Anemia Falciforme para acompanhamento da implantação do Programa de Atenção Integral às Pessoas com Doenças Falciformes e outras Hemoglobinopatias da Cidade de São Paulo, formado por técnicos das três esferas governamentais instituições privadas de Saúde, organizações não governamentais, Conselho Municipal de Saúde, CONE e hospitais municipais; a identificação das patologias prevalentes e de maior risco para a população negra. Segundo o censo realizado em 2010, a população negra representava no Município 7\% da população, ou seja, 4.169.301 habitantes.

Examinamos até aqui a política pública de igualdade racial no município de São Paulo em alguns aspectos formais. Passaremos para a análise crítica da execução dessa referida política na área da saúde quanto aos respeito à dignidade das mulheres negras tendo por base os dados do SINASC (Sistema de Informações de Nascidos Vivos)/SMS (Secretaria Municipal de Saúde) - do ano de 2011 atualizados em 2 de agosto de 2012 e disponibilizados pelo Observatório Cidadão Nossa São Paulo: disponível em: http://www.nossasaopaulo.org.br/observatorio/indicadores.php?tema=10.

O indicador social que chamou a nossa atenção pela inclusão do quesito cor foi a relação pré-natal insuficiente negros x não negros nas Subprefeituras (divisões administrativas do município). O indicador escolhido demostra que é maior o número de casos de pré-natal insuficiente entre as mulheres negras do que entre as não negras. Neste caso, o indicador 1,00 significa igualdade e 1,90, por exemplo, 
significa que as mulheres negras apresentam 90\% mais casos de pré-natal insuficiente.

Fator de desigualdade subprefeituras: 7,5

Fator de desigualdade distritos: 27,0

Subprefeituras melhores e piores em 2011

\begin{tabular}{|c|c|c|}
\hline \multirow{3}{*}{$\uparrow$} & M'Boi Mirim & 0,96 \\
\hline & Ermelino Matarazzo & 1,00 \\
\hline & Parelheiros & 1,06 \\
\hline \multicolumn{2}{|c|}{ Município de São Paulo } & 1,45 \\
\hline \multirow{3}{*}{$\downarrow$} & Santo Amaro & 3,71 \\
\hline & Vila Mariana & 5,57 \\
\hline & Pinheiros & 7,26 \\
\hline
\end{tabular}

Unidade: proporção

Distritos melhores e piores em 2011

\begin{tabular}{|c|c|c|}
\hline \multirow{3}{*}{$\uparrow$} & Barra Funda & 0,00 \\
\hline & Sé & 0,73 \\
\hline & Pari & 0,87 \\
\hline \multicolumn{2}{|c|}{ Município de São Paulo } & 1,45 \\
\hline \multirow{3}{*}{$\downarrow$} & Itaim Bibi & 8,48 \\
\hline & Alto de Pinheiros & 11,89 \\
\hline & Moema & 19,61 \\
\hline
\end{tabular}

Unidade: proporção 
FONTE: SINASC (Sistema de Informações de Nascidos Vivos)/SMS (Secretaria Municipal de Saúde) - do ano de 2011 atualizados em 2 de agosto de 2012.

É possível afirmar apenas com a apresentação de um indicador social, que é evidente a necessidade do alcance de metas mais adequadas ao princípio da dignidade humana na política pública de direito à saúde da mulher negra no município de São Paulo. Nas regiões de maior contingente populacional do segmento negro (Zona Sul e Zona Leste) verificamos o maior grau de desigualdade, nocivo às mulheres negras.

Para contribuir para um novo capítulo dos Direitos Humanos das Mulheres Negras, formulamos uma proposta de Educação para Direitos Humanos como diferencial para a promoção dessa temática. Nossa sugestão está baseada na abordagem sociocultural da educação e na andragogia.

A abordagem sociocultural da Educação teve origem no final dos anos 1970 e início dos 1980 coincidindo com a redemocratização. Nessa teoria, educadores/as e educandos/as são mediados pela realidade social e atuam como agentes transformadores. No processo de ensino-aprendizagem da Educação para Direitos Humanos, especificamente, temos a organização de ações centradas na redução dos fatores determinantes das desigualdades sociais, econômicas e políticas no interior da sociedade.

A abordagem sociocultural da Educação para Direitos Humanos na promoção dos Direitos Humanos das Mulheres Negras corresponde à uma etapa de reflexão sobre o valor de sua dignidade e a passagem para uma consciência ativa e crítica. Essa postura de reflexão passa pela apropriação da História das Mulheres 
Negras em território brasileiro e das características das nossas relações de poder e dominação.

Sob o eixo da andragogia (a prática do ensino para adultos), a Educação para Direitos Humanos para a promoção da saúde integral da Mulher Negra constitui-se das experiências das próprias mulheres negras, distintas das outras mulheres e dos homens negros. A Educação para Direitos Humanos será de utilidade para o melhor enfrentamento dos problemas na esfera pessoal e na vida comunitária. Nas mulheres negras adultas o processo de ensino-aprendizagem deve ser voltado para novas práticas cotidianas que efetivem autoestima, qualidade de vida etc. Na Educação para Direitos Humanos andragógica optamos por um caminho de compreensão da mulher negra nas suas dimensões psicológicas, biológicas e sociais. 


\section{CONSIDERAÇÕES FINAIS}

É fato que ser mulher e negra implica em uma série de enfrentamentos, lutas constantes, busca de superação e falta de oportunidades no Brasil. A análise que desenvolvemos procurou demonstrar que a construção dos Direitos Humanos no Brasil depende, notadamente, da efetivação do direito à saúde da mulher negra.

O direito fundamental à saúde da mulher negra está assegurado tanto na legislação internacional quanto no ordenamento jurídico interno. As justificativas e as diretrizes para a eliminação de qualquer discriminação de gênero e raça são normas de aplicação imediata.

Verificamos que no aspecto formal a política pública para a promoção do direito fundamental da mulher negra como elemento essencial da sua dignidade humana depende agora de práticas cotidianas de sensibilização e concretização.

Dessa forma pudemos observar que a constitucionalização do Direito Sanitário, a teoria da Política Pública e o direito à igualdade racial estão vinculados. Destacamos os avanços obtidos com os documentos internacionais de Direitos Humanos, a Constituição de 1988 e o Sistema Único de Saúde (SUS) e o Estatuto da Igualdade Racial, destinados a garantir a efetivação da igualdade de oportunidades, a defesa dos direitos, o combate à discriminação racial e de gênero que assolam a população negra feminina.

Nossa proposta de Educação para Direitos Humanos é de natureza multidisciplinar como todos os temas dessa Área. Os elementos esboçados são 
válidos para o aprimoramento da política pública de promoção do direito à saúde da mulher negra paulistana.

A dignidade da mulher negra paulistana nas ações e serviços de saúde não está pronta e acabada. Ao contrário, é produto das decisões e de homens, mulheres, brasileiros e estrangeiros que, de diferentes formas (pesquisas científicas, participação político-partidária, gestão e execução de políticas públicas, militância em direitos humanos) interagiram e interagem em uma dinâmica cujo resultado, esperamos, seja uma civilização brasileira com mais justiça social, mais qualidade de vida e cidadania. 


\section{REFERÊNCIAS BIBLIOGRÁFICAS}

[1] http://redesaudedapopulacaonegra.org/wpcontent/uploads/2010/04/Dco base PopulacaoNegra.pdf

AITH, Fernando Mussa Abujamra Consolidação do Direito Sanitário no Brasil In: O Direito achado na rua : Introdução crítica ao direito à saúde. / Alexandre Bernardino Costa ... [et al.](organizadores) - Brasília: CEAD/ UnB, 2009

Articulação de Organizações de Mulheres Negras Brasileiras Saúde da mulher negra: guia para a defesa dos direitos das mulheres negras / Articulação de Organizações de Mulheres Negras Brasileiras. - Porto Alegre, 2012

As políticas públicas e a desigualdade racial no Brasil : 120 anos após a abolição / Mário Theodoro (org.),Luciana Jaccoud, Rafael Osório, Sergei Soares . -Brasília : Ipea, 2008.176 p. : gráfs., tabs.

BARROS, Elizabeth. O controle social e o processo de descentralização dos serviços de saúde.In: BRASIL. Ministério da Saúde. Coordenação de Informação, Educação e Comunicação. Incentivos à participação popular e controle social do SUS: textos técnicos para conselheiros de saúde. Brasília, 1998, p.19

BATISTA, Luis Eduardo e MONTEIRO, Rosana Batista. "Política de Saúde da População Negra no Estado de São Paulo: focalizando para promover a universalização do direito à saúde? In: BIS, Bol. Inst. Saúde (Impr.) v.12 n.2 São Paulo ago. 2010

BOBBIO, Norberto. A era dos direitos. Rio de Janeiro: Elsevier, 2004

BOBBIO, Norberto. Era dos Direitos, tradução Carlos Nelson Coutinho, Rio de Janeiro, Campus, 1988.

BONAVIDES, Paulo. Curso de Direito Constitucional. 19a Edição, São Paulo : Editora Malheiros, 2006.

BUCCI, Maria Paula Dallari. O conceito de política pública em direito.In: BUCCl, Maria Paula Dallari ( org.).Políticas públicas: reflexões sobre o conceito jurídico. São Paulo: Saraiva, 2006.

BULL, Hedley. A sociedade anárquica Universidade de Brasilia, Instituto de Pesquisa de Relações Internacionais, São Paulo, Imprensa Oficial do Estado, 2002, 
CANOTILHO, J.J.Gomes . Direito Constitucional e Teoria da Constituição, 7ª̣ ed., Coimbra, Almedina.

CAPELLA, Ana Cláudia N., Perspectivas Teóricas sobre o Processo de Formulação de Políticas Públicas In: BIB, São Paulo, nำ 61, 1ํ semestre de 2006.

CARNEIRO, Sueli. Enegrecer o feminismo: a situação da mulher negra na América Latina a partir de uma perspectiva de gênero. Este artigo foi apresentado no Seminário Internacional sobre Racismo, Xenofobia e Gênero, organizado por Lolapress em Durban, África do Sul, em 27 - 28 de agosto 2001.Publicado em espanhol na revista LOLA Press nำ16, novembro 2001

CASTELLS, Manuel. A Crise da Democracia, Governança Global e a Emergência de uma Sociedade Civil Global. In: Por uma Governança Global Democrática (vários autores). São Paulo: Instituto Fernando Henrique Cardoso, 2005.

COMPARATO, Fábio Konder. A afirmação histórica dos direitos humanos.São Paulo: Saraiva, 2010.7.ed.rev. e atual.

COMPARATO, Fábio Konder. A afirmação histórica dos direitos humanos.3aa ed.São Paulo: Saraiva, 2004, p.26.

COMPARATO, Fábio Konder. Fundamento dos Direitos Humanos. Texto disponível em: http://iea.usp.br/artigos.

Conquistando Direitos- a Experiência do Projeto Piloto Direito à Saúde da Mulher Negra. Coordenado por Bruna Angotti e Nathalie Nunes. São Paulo: Conectas Direitos Humanos, 2010.

Coordenadoria dos Assuntos da População Negra 20 anos de contribuição para as Políticas Públicas Etnicorraciais no município de São Paulo. Organização: Maria Aparecida de Laia. Prefeitura de São Paulo. Coordenadoria dos Assuntos da População Negra- CONE. Imprensa Oficial do Estado de São Paulo. 2012.

CRENSHAW, Kimberlé. Documento para o encontro de especialistas em aspectos de discriminação racial relativos ao gênero. Revista Estudos Feministas. Vol.10. ํㅜ1. Florianópolis. Jan. 2002.

Curso de capacitação de conselheiros gestores/Secretaria Municipal de Saúde. Coordenação de Gestão de Pessoas. Diretoria de Gestão de Desenvolvimento de Pessoas. Escola Municipal de Saúde/CEFOR/ETSUS-SP. São Paulo: Secretaria da Saúde, 2011.

DALLARI, Dalmo de Abreu. Ética Sanitária. In: Curso de Especialização a Distância em Direito Sanitário para membros do Ministério Público e da Magistratura Federal.

DALLARI, S. G. O direito à saúde. Rev. Saúde públ., S. Paulo, 22:57-63, 1988.

DALLARI, Sueli Gandolfi. A construção do direito à saúde no Brasil. Revista de Direito Sanitário, São Paulo, v. 9, n.3. 
Declaração Universal dos Direitos Humanos http://portal.mj.gov.br/sedh/ct/legis intern/ddh bib inter universal.htm

DELDUQUE, Maria Célia; OLIVEIRA, Mariana S. de Carvalho. Tijolo por tijolo: a construção permanente do direito à saúde. In: O Direito achado na rua : Introdução crítica ao direito à saúde. / Alexandre Bernardino Costa ... [et al.](organizadores) Brasília: CEAD/UnB, 2009.

FALLETI, T." INFILTRANDO O ESTADO: A EVOLUÇÃO DA REFORMA DA GANDOLFI, Sueli Dallari. Direito Sanitário. Curso de Especialização a Distância em Direito Sanitário para membros do Ministério Público e da Magistratura Federal

HONNETH, Axel. Reconhecimento ou redistribuição? A mudança de perspectivas na ordem moral da sociedade. In: SOUZA, Jessé; MATTOS, Patrícia (orgs.). Teoria Crítica no século XXI. São Paulo: Annablume, 2007.

http://telecentros.sp.gov.br/img/arquivos/relatorio conselho cone 0910.pdf

\section{https://www.presidencia.gov.br/seppir}

JERICÓ, Marli de Carvalho, PERES, Aida Maris e KURCGANT, Paulina. Estrutura Organizacional do serviço de enfermagem: reflexões sobre a influência do poder e da cultura organizacional.In: Revista da Escola de Enfermagem da Universidade de São Paulo, 2008; 42(3).

LEMOS, Rosália de Oliveira. A face negra do feminismo: problemas e perspectivas. In: O livro da saúde das mulheres negras: nossos passos vem de longe/ (organização) Jurema Werneck, Maisa Mendonça, Evelyn C. White; ( tradução) Maisa Mendonça, Marilena Agostini e Maria Cecília MacDowell dos Santos.- Rio de Janeiro: Pallas: Criola, 2000.

LOPES, Fernanda, WERNECK, Jurema. Saúde da população negra. Da conceituação às políticas públicas de direito. In: Mulheres Negras :um Olhar sobre as Lutas Sociais e as Políticas Públicas no Brasil. Organizadora Jurema Werneck. Rio de Janeiro: Criola, 2012.

LUZ, Madel Therezinha. Duas questões permanentes em um século de políticas de saúde no Brasil republicano. Ciência \& Saúde Coletiva, 5(2):293-312, 2000.

MACHADO, Cristiani Vieira, BAPTISTA,Tatiana Wargas de Faria, LIMA, Luciana Dias de. O planejamento nacional da política de saúde no Brasil: estratégias e instrumentos nos anos 2000. Ciência \& Saúde Coletiva, 15(5):2367-2382, 2010.

MAUÉS, Antonio G. Moreira e SIMÕES, Sandro Alex de. Direito Público Sanitário Constitucional.Curso de Especialização a Distância em Direito Sanitário para membros do Ministério Público e da Magistratura Federal.

Pacto Internacional de Direitos Econômicos, Sociais e Culturais http://portal.mj.gov.br/sedh/ct/legis intern/pacto dir economicos.htm 
PIOVESAN, Flávia. "Os direitos humanos da mulher na ordem internacional". In: Temas de Direitos Humanos. São Paulo: Max Limonad, 2003.

PIOVESAN, Flávia. Direitos Humanos e o Direito Constitucional Internacional, Segunda Parte, Cap. V, d. São Paulo, Max Limonad.

Política Nacional de Saúde Integral da População Negra. Ministério da Saúde. Secretaria de Gestão Estratégica e Participativa. Brasília, DF . Fevereiro de 2007.

PRUDENTE, Eunice Aparecida de Jesus. Educação em Direitos- um caminho para a Igualdade Racial.

PRUDENTE, Eunice Aparecida de Jesus. Preconceito racial e igualdade jurídica no Brasil. (Dissertação/Mestrado), Faculdade de Direito da Universidade de São Paulo.

RODRIGUEZ NETO, Eleutério. A Reforma Sanitária e o Sistema Único de Saúde: suas origens, suas propostas, sua implantação, suas dificuldades e suas perspectivas. In: Brasil. Ministério da Saúde. Coordenação de Informação, Educação e Comunicação. Incentivos à participação popular e controle social no SUS: textos técnicos para conselheiros de saúde. Brasília, 1998.

SANTOS, Gislene Aparecida dos. As políticas multiculturais e o reconhecimento de identidades como novas formas de contrato social e efetivação da justiça. CCJUR em Revista , 2010, ISSN 1679-4206 [no prelo

SANTOS, Milton. Por uma outra globalização: do pensamento único à consciência universal. Rio de Janeiro, Record, 2000.

SANTOS, Sales Augusto dos; SANTOS, João Vitor Moreno dos; e BERTÚLIO, Dora Lúcia. O processo de aprovação do Estatuto da Igualdade Racial, Lei n. .12 .288 , de 20 de julho de 2010. Brasília: INESC, 2011.

SARLET, Ingo Wolfgang. Dignidade da pessoa humana e direitos fundamentais na Constituição Federal de 1988. 5. Ed. rev. Atual - Porto Alegre: Livraria do Advogado, Ed., 2007

SARTI, Cynthia Andersen . O feminismo brasileiro desde os anos 1970: revisitando uma trajetória. Estudos Feministas, Florianópolis, 12(2): 35-50, maio-agosto/2004.

Saúde da mulher negra: guia para a defesa dos direitos das mulheres negras / Articulação de Organizações de Mulheres Negras Brasileiras. - Porto Alegre, 2012.

Saúde da população negra / Luís Eduardo Batista, Jurema Werneck e Fernanda Lopes, (orgs.). --2. ed. rev. e ampl., 1. reimpr. -- Brasília, DF

SAÚDE NO BRASIL, 1964 - 1988" Tradução: Alan César Belo ANGELUCI Estud. sociol., Araraquara, v.15, n.29, p.345-368, 2010

SCAVONE, Lucila. Dar a vida e cuidar da vida: feminismo e ciências sociais. São Paulo: Editora UNESP, 2004.

SCOTT, Joan. Gênero, uma categoria útil de análise histórica. Educação e Realidade. Porto Alegre, v. 16, n.2, jul-dez, 1990. 
SILVA JR, Hédio. A gestão e o controle social de políticas públicas In: Políticas Públicas de Promoção da Igualdade Racial. Organização Hédio Silva Júnior, Maria Aparecida da Silva Bento, Rogério Silva; vários autores. São Paulo, SP: CEERT, 2010.

SILVA, José Afonso da. A dignidade da pessoa humana como valor supremo da democracia. Revista de Direito Administrativo. Rio de Janeiro: volume 212, abril e junho de 1998

SILVA, José Afonso da. Curso de Direito Constitucional Positivo.24á edição, 2005, Malheiros Editores.

SOIHET, Rachel e PEDRO, Joana Maria. A emergência da pesquisa da História das Mulheres e das Relações de Gênero. In: Revista Brasileira de História. São Paulo, v. 27 , no 54 , p. $281-300-2007$.

TAYLOR, Charles (2000). "Propósitos entrelaçados: o debate liberal-comunitário". In: Taylor, Charles. Argumentos filosóficos. São Paulo: Loyola.

TAYLOR, Charles. Argumentos Filosóficos. São Paulo: Loyola, 2000

TRINDADE, Antonio Augusto Cançado. A Proteção Internacional dos Direitos Humanos. São Paulo: Saraiva, 1991.

WEISS, Carlos. Direitos Humanos Contemporâneos, Cap. 2, item 1.

WERNECK, Jurema ( Org.), Mulheres Negras: um olhar sobre as lutas sociais e as políticas públicas no Brasil. Publicação da Organização Não Governamental CRIOLA. 